\title{
Umatilla River Fish Passage Operations Project Annual Progress Report October 2007 - September 2008
}

\author{
Prepared by \\ James $\mathrm{P}$. Bronson \\ Fisheries Program, Department of Natural Resources \\ Confederated Tribes of the Umatilla Indian Reservation
}

\author{
And \\ Ken Loffink and Bill Duke \\ Oregon Department of Fish and Wildlife
}

Funded by

U.S. Department of Energy

Bonneville Power Administration

Division of Fish and Wildlife

Timmie Mandish, COTR

P.O. Box 3621

Portland, OR 97208-3621

Project No. 1988-022-00

Contract No. 00004112

December 2008 


\section{TABLE OF CONTENTS}

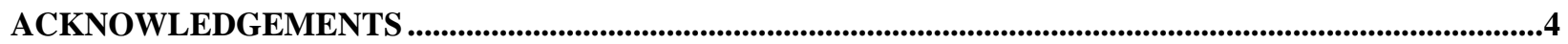

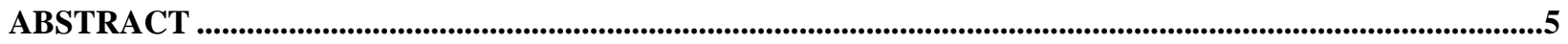

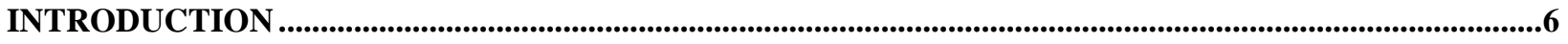

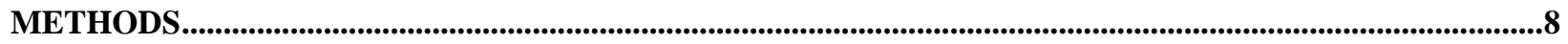

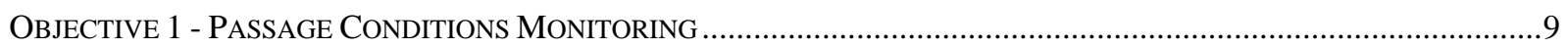

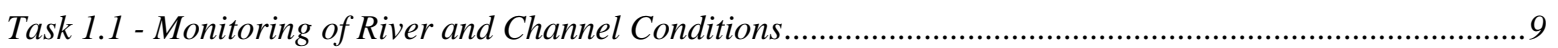

Task 1.2 - Inspection of Passage Facilities.................................................................................................

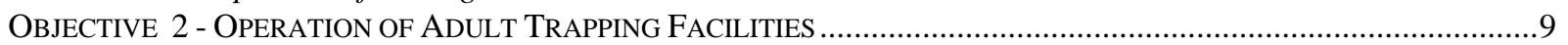

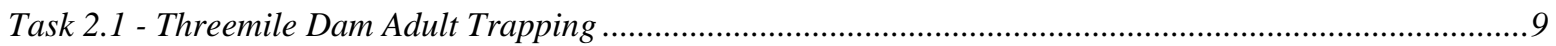

Task 2.2 - Westland Adult Trapping .............................................................................................................

OBJECTIVE 3 - OPERATION OF JUVENILE TRAPPING FACILITIES ........................................................................11

Task 3.1 - Westland Juvenile Facility Operation .....................................................................................11

Task 3.2 - Threemile Dam Juvenile Facility Operation.....................................................................................12

OBJECTIVE 4 - ADULT AND JUVENILE TRANSPORTATION..............................................................................12

Task 4.1 - Threemile Dam Adult Hauling .............................................................................................12

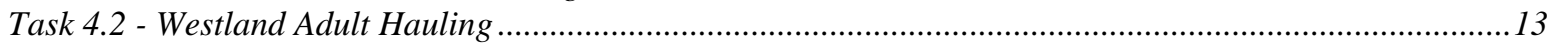

Task 4.3 - Westland Juvenile Hauling ..........................................................................................................

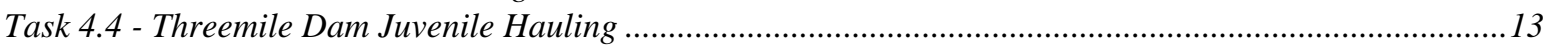

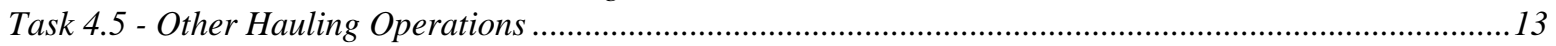

OBJECTIVE 5 - COORDINATION OF PASSAGE PROGRAM ……...........................................................................13

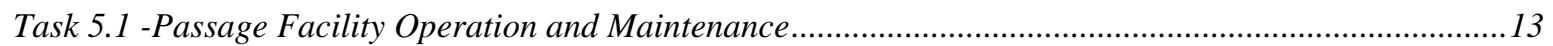

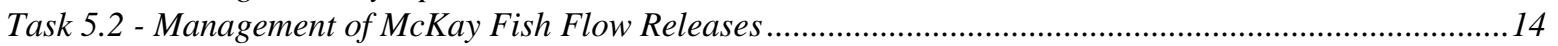

Task 5.3 - Coordination of Exchange Program ..................................................................................................15

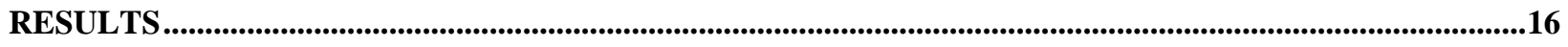

OBJECTIVE 1 - PASSAGE CONDITIONS MONITORING …………...................................................................................16

Task 1.1 - Monito ring of River and Channel Conditions.........................................................................16

Task 1.2 - Inspection of Passage Facilities.....................................................................................................16

OBJECTIVE 2 - OPERATION OF ADULT TRAPPING FACILITIES ...........................................................................16

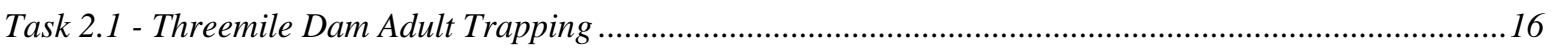

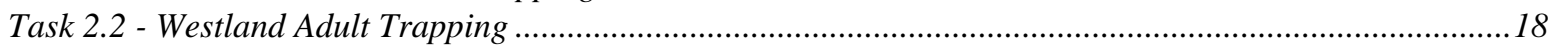

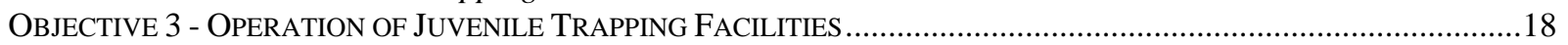

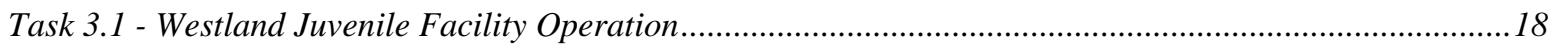

Task 3.2 - Threemile Dam Juvenile Facility Operation...................................................................................18

OBJECTIVE 4 - ADULT AND JUVENILE TRANSPORTATION....................................................................................19

Task 4.1 - Threemile Dam Adult Hauling .......................................................................................................19

Task 4.2 - Westland Adult Hauling ................................................................................................................20

Task 4.3 - Westland Juvenile Hauling .....................................................................................................

Task 4.4 - Threemile Dam Juvenile Hauling ..................................................................................................

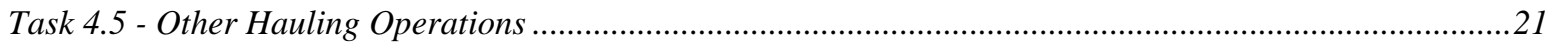

OBJECTIVE 5 - COORDINATION OF PASSAGE PROGRAM ……….......................................................................21

Task 5.1 - Passage Facility Opertion and Maintenance Oversight ................................................................21

Task 5.2 - Management of McKay Fish Flow Releases ..................................................................................22

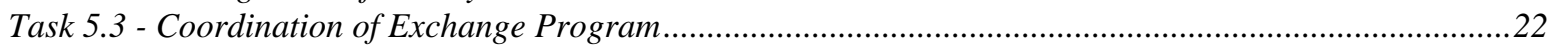




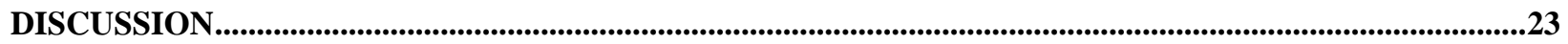

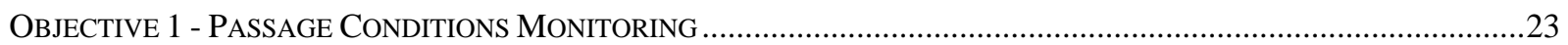

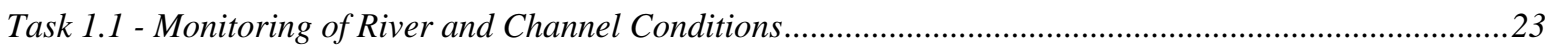

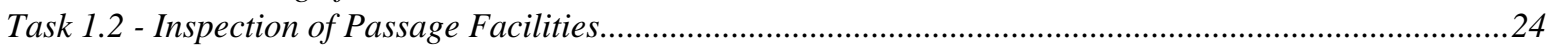

OBJECTIVE 2 - OPERATION OF ADULT TRAPPING FACILITIES ................................................................................25

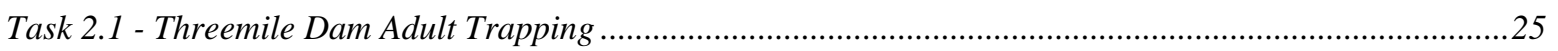

Task 2.2 - Westland Adult Trapping .............................................................................................................2

OBJECTIVE 3 - OPERATION OF JUVENILE TRAPPING FACILITIES ...........................................................................27

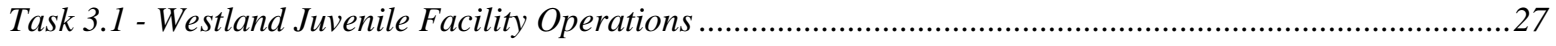

Task 3.2 - Threemile Dam Juvenile Facility Operations ..................................................................................28

OBJECTIVE 4 - AdULT AND JUVENILE TRANSPORTATION.................................................................................28

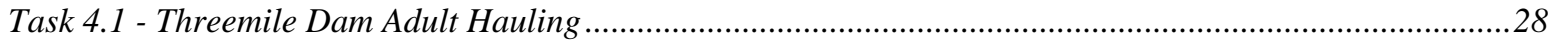

Task 4.2 - Westland Adult Hauling ...............................................................................................................29

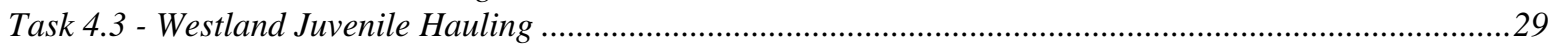

Task 4.4 - Threemile Dam Juvenile Hauling ....................................................................................................

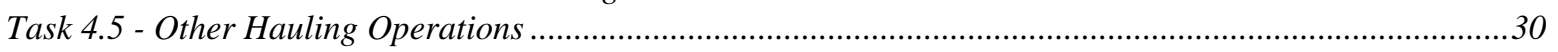

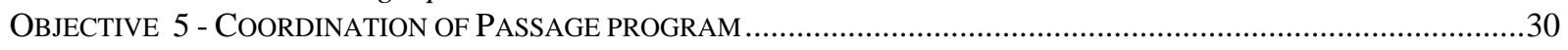

Task 5.1- Passage Facility Operation and Maintenance Oversight ...................................................................30

Task 5.2 - Management of McKay Fish Flow Releases ...................................................................................30

Task 5.3 - Coordination of Exchange Program .................................................................................................32

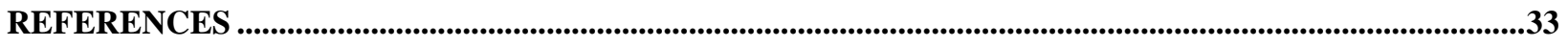

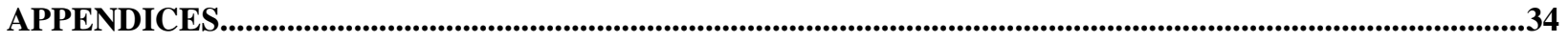

Appendix A: 2007-2008 Adult Returns

Appendix B: 2007-2008 Adult Transportation Summary

Appendix C: 2007-2008 Juvenile Transportation Summary

Appendix D: 2007-2008 Umatilla Hatchery and Basin AOP 


\section{ACKNOWLEDGEMENTS}

This program was funded by Bonneville Power Administration (BPA). The Confederated Tribes of the Umatilla Indian Reservation (CTUIR) and Oregon Department of Fish and Wildlife (ODFW) thank Jonathan McCloud and Timmie Mandish of BPA for their project assistance.

Thanks are also extended to the Hermiston field office and Pendleton District Office of ODFW; the Oregon Water Resources Department; the Umatilla Passage Facility Operation and Maintenance crew; and Stanfield, Westland, Hermiston, and West Extension irrigation districts.

Thanks to CTUIR staff for their cooperation and contributions in developing this report. In particular, Robert Van Pelt and Tysen Minthorn, project technicians; Chet Tias and Ron Fossek, facility watch personnel; Gerry Rowan, data collection; Brian Zimmerman, technical oversite and report review; and Michelle Thompson and Julie A. Burke, administrative management. Celeste Reves and Brandie Bill provided secretarial assistance. 


\begin{abstract}
Threemile Falls Dam (Threemile Dam), located near the town of Umatilla, is the major collection and counting point for adult salmonids returning to the Umatilla River. Returning salmon and steelhead were enumerated at Threemile Dam from June 7, 2007 to August 11, 2008. A total of 3,133 summer steelhead (Oncorhynchus mykiss); 1,487 adult, 1,067 jack, and 999 subjack fall Chinook (O. tshawytscha); 5,140 adult and 150 jack coho (O. kisutch); and 2,009 adult, 517 jack, and 128 subjack spring Chinook (O. tshawytscha) were counted. All fish were enumerated at the east bank facility.

Of the fish counted, 1,442 summer steelhead and 88 adult and 84 jack spring Chinook were hauled upstream from Threemile Dam. There were 1,497 summer steelhead; 609 adult, 1,018 jack and 979 subjack fall Chinook; 5,036 adult and 144 jack coho; and 1,117 adult, 386 jack and 125 subjack spring Chinook either released at, or allowed to volitionally migrate past, Threemile Dam. Also, 110 summer steelhead; 878 adult and 43 jack fall Chinook; and 560 adult and 28 jack spring Chinook were collected as broodstock for the Umatilla River hatchery program. In addition, there were 241 adult and 15 jack spring Chinook collected at Threemile Dam for outplanting in the South Fork Walla Walla River and Mill $\mathrm{Cr}$, a tributary of the mainstem Walla Walla River.
\end{abstract}

The Westland Canal juvenile facility (Westland), located near the town of Echo at river mile (RM) 27, is the major collection point for out-migrating juvenile salmonids and steelhead kelts. The canal was open for 158 days between February 11, 2008 and July 18, 2008. During that period, fish were bypassed back to the river 150 days and were trapped 6 days. There were also 2 days when fish were directed into and held in the canal forebay between the time the bypass was closed and the trap opened. An estimated 64 pounds of fish were transported from the Westland trapping facility. Approximately $25.8 \%$ of the fish transported were salmonids. In addition, one adult Pacific lamprey was trapped and released above the Westland ladder this year.

The Threemile Dam west bank juvenile bypass was opened on March 11, 2008 in conjunction with water deliveries and continued through the summer. West Extension Irrigation District (WEID) discontinued diverting live flow on June 24, 2008 but the bypass remained open throughout the project year. The juvenile trap was not operated this project year. 


\section{INTRODUCTION}

The Confederated Tribes of the Umatilla Indian Reservation (CTUIR) and Oregon Department of Fish and Wildlife (ODFW) are cooperatively working to rehabilitate runs of coho, fall and spring chinook and summer steelhead in the Umatilla River Basin (Figure 1). The Bonneville Power Administration (BPA) and other federal agencies are funding several projects to accomplish that goal (CTUIR, et al. 2001). Included among these projects is Umatilla River Fish Passage Operations (formerly known as Trap and Haul, project number 198802200).

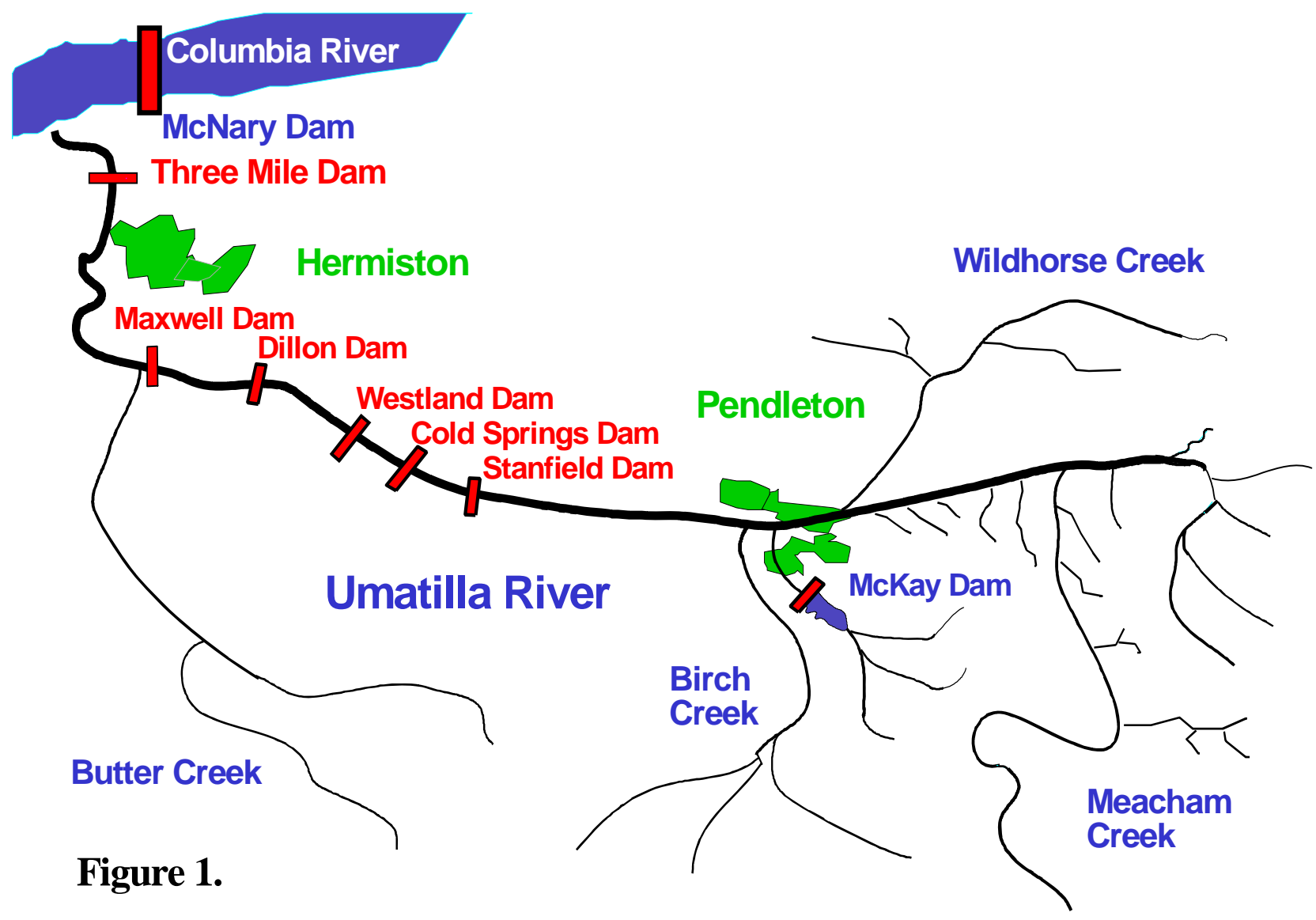

The lower 32 miles of the Umatilla River historically provided obstacles to the migration of both adult and juvenile salmonids. Passage inadequacies have been identified as a major contributor to the decline of summer steelhead and extinction of salmon populations in the basin (CTUIR, et al. 2001, CTUIR \& ODFW 1989, CTUIR \& ODFW 1990, ODFW 1986). During both juvenile and adult migration periods, parts of the lower river between the mouth and Stanfield Dam were dewatered, stranding migrating salmonids. The U.S. Fish and Wildlife Service (USFWS) (1981) and U.S. Bureau of Reclamation (BOR) (1988) identified flows ranging from 150 cubic feet per second (cfs) to 300 cfs as being necessary for fish passage through this river reach. With implementation of the Umatilla Basin Project, the duration and extent of these low flow periods have decreased substantially from what occurred historically. 
In addition to low flows, diversion structures associated with irrigation canals also provided physical barriers to passage. Adult ladder and juvenile screen and bypass improvements have been completed at most diversions in the basin. With implementation of these flow enhancement and physical passage improvements, passage conditions have improved dramatically. However, even with these improvements in place there are still periods when inadequate passage conditions may occur.

Initially, this project was implemented as the Umatilla River Trap and Haul project in 1989. The primary responsibility of the project through the early years was to capture and safely transport adult and juvenile migrants around dewatered stream reaches in the lower basin. The project has evolved with implementation of the flow enhancement and fish passage improvements in the basin. The project title changed to the Umatilla River Fish Passage Operations in 1999 to more accurately reflect the transformations which have occurred within the project and in the overall passage program in the basin. While transportation is still an important function, operation and coordination of flow enhancement efforts and passage facilities are now the major focus for the project.

The objective of the Umatilla River Fish Passage Operations Project is to maximize survival of adult and juvenile salmonids migrating through the lower Umatilla River. The project has four primary areas of responsibility to meet this objective: 1) Monitoring of flow and passage conditions in the basin; 2) Daily operation and refinement of operating criteria for passage and trapping facilities, and transportation equipment; 3) Oversight of the flow enhancement effort (Umatilla Basin Project); and 4) Coordination of the overall fish passage program. It is critical that facility operations and flow enhancement efforts are coordinated with passage requirements to ensure that optimal passage conditions exist and passage inadequacies are no longer a limiting factor to restoration efforts in the basin.

The reporting period for the annual report is October through September. This reporting period covers the same operational time frame as that outlined in the Umatilla Hatchery and Basin Annual Operating Plan (AOP). 


\section{METHODS}

\section{Objective 1 - Passage Conditions Monitoring}

Task 1.1 - Monitoring of River and Channel Conditions

Temperatures are monitored during the project year to help refine project operating guidelines. Temperatures for the lower Umatilla River are measured by a digital recording thermometer located at the UMAO hydromet site (RM 2). In addition, the project accesses available temperature information located at most of the hydromet sites. Instantaneous temperatures are measured daily at Threemile Dam during trapping operations and at loading stations and release sites with hand held thermometers.

Daily river flow is monitored at Pendleton (RM 54), Yoakum (RM 37), Dillon (RM 24.5) and Umatilla (RM 2). Daily irrigation usage is monitored for Stanfield, Westland, Feed, Maxwell, and West Extension canals. River flow and irrigation diversion data is provided by Oregon Department of Water Resources (OWRD) from the Hydromet flow gauging stations.

Channel conditions are monitored during the project year to ensure adequate entrance and exit conditions are present at the passage facilities. Visual observations are conducted multiple times per week to document channel morphology in association with flows to the passage facilities. Investigating fish behavior associated with current passage conditions is important in refining operating criteria for both upstream and downstream migrations.

Task 1.2 - Inspection of Passage Facilities

Table 1. BPA Passage Facilities

\begin{tabular}{|l|l|}
\hline Location & Passage Facilities \\
\hline Stanfield Canal & Adult ladder and juvenile screens \\
\hline Cold Springs Canal & Adult ladder and juvenile screens \\
\hline Westland Canal & $\begin{array}{l}\text { Adult ladder, juvenile screens and downstream migrant } \\
\text { trap }\end{array}$ \\
\hline Maxwell Canal & Juvenile screens \\
\hline Threemile Dam West Bank & $\begin{array}{l}\text { Juvenile screens and downstream migrant collection } \\
\text { facility }\end{array}$ \\
\hline Threemile Dam East Bank & Adult ladder and trapping facility \\
\hline
\end{tabular}

Juvenile fish screens/bypasses and adult ladder facilities, associated with irrigation diversions within the basin, are monitored throughout the year to ensure that adequate passage conditions exist for upstream and downstream migrants. These include both the BPA funded passage facilities included in Table 1 as well as Mitchell Act and private facilities at smaller diversions in the basin. Inspections include checking for proper installation and operation of screens, gaps and holes in screens or seals, debris buildup on 
screens and trash racks, proper flows to smolt bypasses and adult ladders, adequate access and exit conditions at bypasses and ladders, and signs of fish activity.

\section{Objective 2 - Operation of Adult Trapping Facilities}

\section{Task 2.1 - Threemile Dam Adult Trapping}

Threemile Dam, located approximately three miles upstream from the mouth of the Umatilla River, is the major collection and counting point for all adults returning to the Umatilla River. The main collection facility is located on the east bank and includes a vertical slot ladder, Denil steeppass, raceway type holding ponds and fish handling and sorting complex (Figure 2). Fish routed through the sorting complex are anesthetized with carbon dioxide $\left(\mathrm{CO}_{2}\right)$ to reduce stress during the handling process. Captured adults can be directed back into the holding pond, into recovery tanks for release upstream of the dam, to a broodstock holding and spawning facility, directly into the dam forebay, or into transport tanks for hauling.

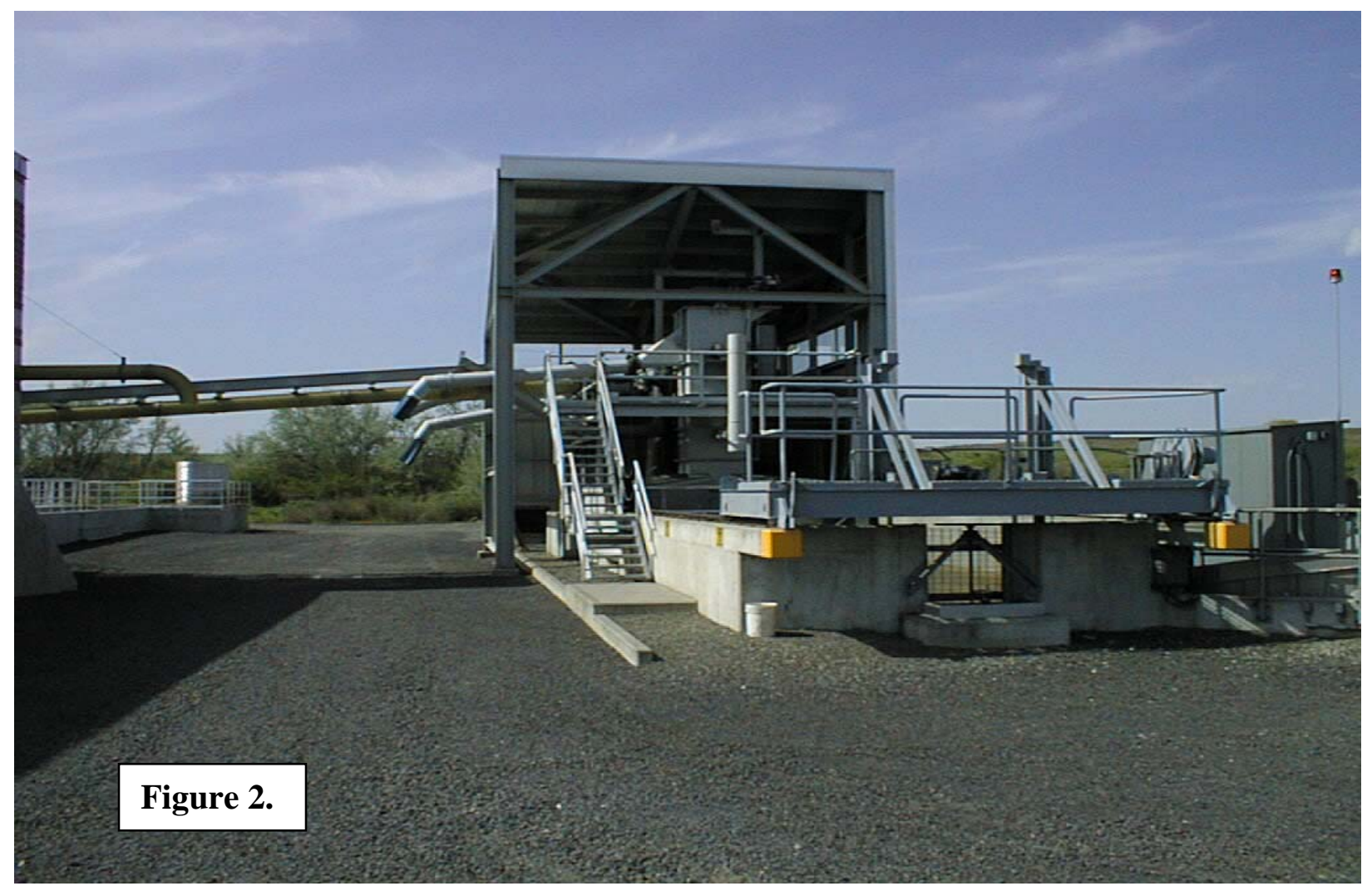

Up until the 1999/2000 return year, all adults returning to Threemile Dam were trapped. That year, criteria were outlined for volitional migration of adults past Threemile Dam with enumeration occurring through video recording. For the past eight years, the AOP (CTUIR \& ODFW 2008) has identified criteria for volitional migration of adults past Threemile Dam. For 2007/2008, the AOP outlined that beginning December first; trapping was to be reduced to five day periods with volitional migration occurring for nine day 
periods. Beginning April 15, trapping was to be reduced to an as needed basis for collection of spring chinook broodstock. Trapping periods would be increased if broodstock collection goals or passage criteria were not being met.

Data collected during adult trapping operations includes date, number of fish trapped, species, age and sex composition, marks and disposition. Observations are also made of marine mammal damage, net marks, mechanical damage, and general fish condition. In addition, fork length, mid-eye/hypural plate (MEHP) length, and snouts are collected from a percentage of the fish with coded wire tags (CWT). During volitional migration periods, enumeration occurred by video camera. Data collected during volitional migration includes date, species, and number of fish moving upstream and downstream, jack or adult salmon, and wild or hatchery steelhead. General observations were also made such as time of movement and other species observed.

Fall and spring Chinook salmon were classified as either adults (fork length greater than or equal to 24 inches) or jacks (fork length less than 24 inches) as outlined in ODFW sport fishing regulations. Subjack (or mini-jack) fall Chinook were defined as less than 15.75 inches in fork length and subjack spring Chinook were defined as less than 15 inches in fork length based upon historical length frequency data (CTUIR files). Coho adults were defined as fork length greater than or equal to 18 inches and jacks as fork length less than 18 inches based upon historical length frequency data (CTUIR files). Based on scale analysis of Umatilla River summer steelhead, adult summer steelhead were classified as either one ocean (S1, fork length less than 26 inches) or two ocean (S2, fork length greater than or equal to 26 inches) (CTUIR files). Visual determinations are made to differentiate resident rainbow trout from summer steelhead (but generally less than 18 inches). Size of bull trout are visually estimated and reported to USFWS personnel.

The east bank facility is manned 24 hours a day during the adult capture season. Permanent, on-site housing is provided for watch personnel. In addition to providing security, watch personnel monitor facility operations, assist trap and haul operations, and make observations of fish activity.

The west bank at Threemile Dam also has an adult collection facility. It consists of a vertical slot ladder, a combination $\mathrm{V}$-trap/holding pond, and fish loading apparatus. The trap/holding pond and fish loading complex have no enumeration or sorting capabilities. The ladder was designed with the ability to enumerate fish using video equipment.

Task 2.2 - Westland Adult Trapping

Summer steelhead kelts may be captured at the Westland Canal juvenile facility during trapping operations. The facility has the ability to bypass kelts downriver during high flows or to trap them for transport during low flow periods. It is generally operated in the bypass mode during the majority of the kelt outmigration period. Other adults (such as spring chinook) may also be captured incidentally at the facility during trapping operations and are held for transport upstream. Information collected from adults trapped at Westland 
includes date, species, and number.

\section{Objective 3 - Operation of Juvenile Trapping Facilities}

\section{Task 3.1 - Westland Juvenile Facility Operation}

The Westland Canal juvenile facility (Figure 3 ) is the major collection point for outmigrating juvenile salmonids. It is intended to be operated whenever Westland Canal is delivering water. The facility consists of rotary drum screens, fish bypass, fish trap, adult/juvenile separator (horizontal bar grader), and adult and juvenile holding ponds.

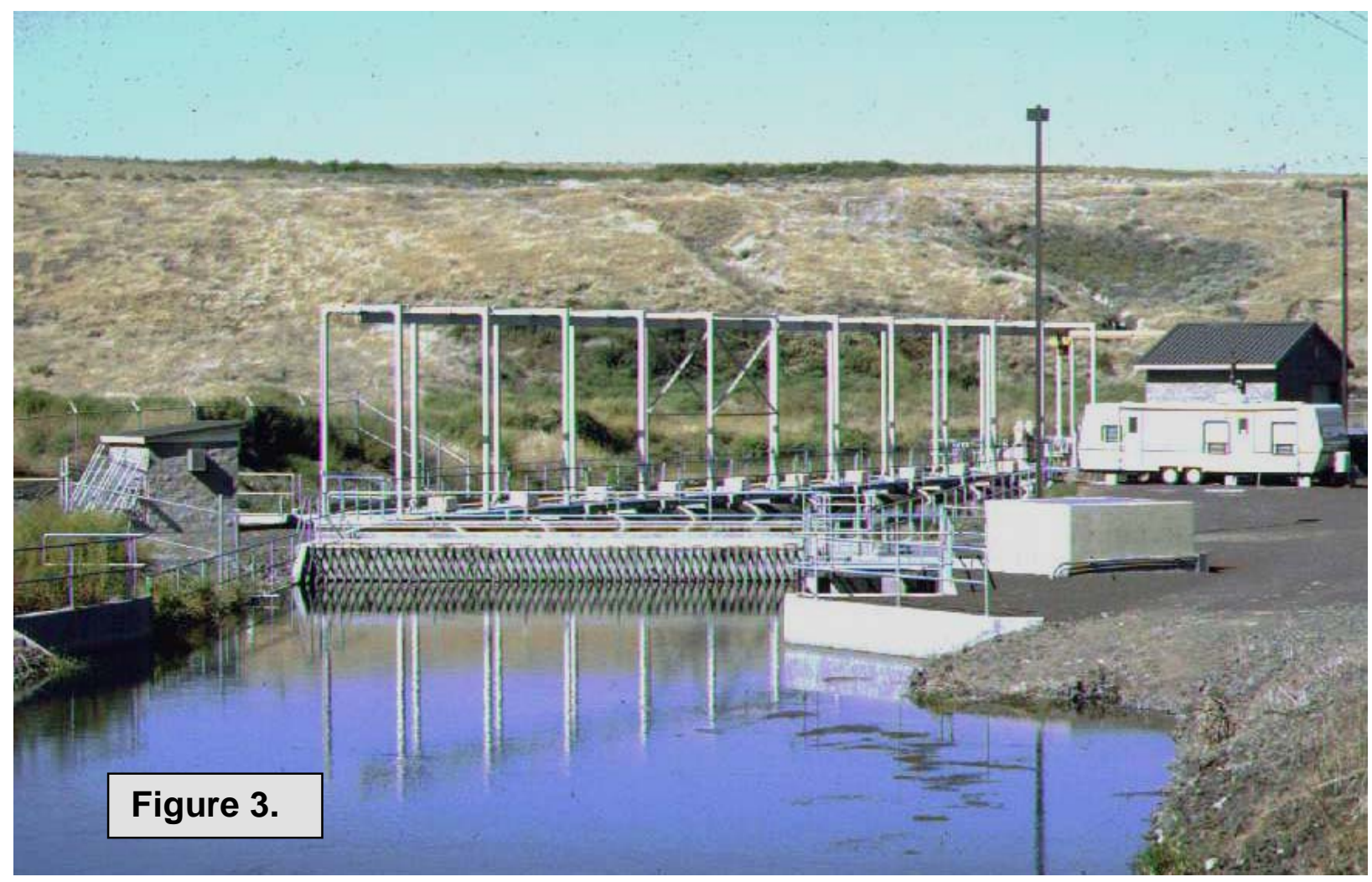

During periods of flow adequate for downstream migration, the facility is designed to operate in the bypass mode. In this mode, fish that enter the irrigation canal are directed back to the river without entering the holding ponds. During periods of inadequate flow, the facility is designed to trap fish, separate juveniles from adults, and direct them to their respective holding units. Juveniles can then be loaded onto trucks or trailers for transport downstream.

Facility trapping operations are coordinated with flow augmentation releases. As river flow drops, the Westland ladder is closed and as much of the river flow as possible is diverted into the Westland Canal headworks and through the juvenile facility prior to being returned to the river. This forces outmigrants into the trapping facility and minimizes the 
number of fish that may become stranded in the low flow river reach below Westland Dam.

Information collected at Westland includes dates of both canal operation and facility operational modes. Because the majority of the fish are now bypassed at Westland rather than trapped, the facility is no longer manned on a 24 hour basis.

Task 3.2 - Threemile Dam Juvenile Facility Operation

A juvenile collection facility is also located at Threemile Dam on the west bank. This facility consists of rotary drum screens, fish bypass channel, fish trap, sampling station and holding tank. It is designed to bypass out-migrating juveniles during periods of adequate flow or to trap them during low flow periods. The trapping portion of this facility was designed as a sampling and evaluation station rather than a production trapping facility. The trap can be used for sampling during bypass periods but is ineffective for trapping and hauling anything but small numbers of fish.

Because of the insufficient trapping capabilities at this site, the operation of the facility is closely coordinated with the Westland facility in order to minimize the number of fish captured at Threemile Dam. Normally, the entire river flow is diverted at Westland to preclude additional downstream volitional movement for a few days prior to the river flow going to zero. This allows smolts located in the reach between Westland and Threemile dams to be migrate out of the system without the need for trapping at Threemile Dam. This combination of flow and facility operational changes at the facility have resulted in it no longer being used for trap and haul purposes. Information collected at Threemile Dam west bank includes dates of both canal operation and facility operational modes.

\section{Objective 4 - Adult and Juvenile Transportation}

Task 4.1 - Threemile Dam Adult Hauling

The Fish Passage Operations program has a 3,500 gallon, 3,000 gallon, and two 370 gallon fish liberation units available for use. The 3,500 gallon unit is a diesel operated tractor- trailer equipped with a 12 inch discharge opening and a single holding chamber. The 3,000 gallon unit is a diesel operated tractor-trailer equipped with a 12 inch discharge opening and two holding chambers capable of isolating two groups in the same load. Both tractor-trailer units are equipped with liquid oxygen and electric aeration to reduce fish stress during transport. The two 370 gallon transport tanks are mounted on dual axle trailers and are pulled by pick-up trucks. Each is equipped with both compressed oxygen aeration and a re-circulation system. Both units have an eight inch discharge opening. These transportation units are used in the Umatilla and Walla Walla basins. ODFW liberation protocols are used as the basic guideline for hauling operations.

In addition to these units, the project also has access to a Bureau of Indian Affairs 750 gallon portable fiberglass tank which can be mounted on a flatbed truck. This unit is also equipped with both compressed oxygen aeration and a re-circulation system and has a 12 inch discharge opening. 
Adult transportation requirements are based on flow criteria outlined in the 1981 USFWS study and past project observations of salmon migrations in the Umatilla River. The AOP also identifies criteria for transportation of adults collected at Threemile Dam. Trap and haul will only be implemented in the fall and winter (August 16 - March 31) if physical passage conditions are unacceptable at Feed Canal Dam. Otherwise all fish will be released at TMFD. During the period from April 1 to early July, trap and haul will be implemented if the passage flow criteria of $150 \mathrm{cfs}$ for 30 days after release cannot be met or if physical passage conditions are unacceptable at Feed Canal Dam. Release sites will be determined based on species composition, fisheries, and river conditions. If flows at Pendleton drop below $250 \mathrm{cfs}$ during this period fish will be hauled upstream and released into the upper basin above Pendleton. The project is also responsible for the collection and transportation of broodstock from Threemile Dam.

Bull trout encountered at Threemile Dam are immediately reported to USFWS field supervisor Paul Sankovich. Bull trout are isolated from other salmonids and held in a separate container. If transport is warranted, bull trout are hauled separately from anadromous salmonids and released at different location.

\section{Task 4.2 - Westland Adult Hauling}

Summer steelhead kelts and other adults may be captured at the Westland Canal juvenile facility during trapping operations. Adults entering the trap can be separated from juveniles by a horizontal bar grader and directed into an adult holding pond. Kelts can then be loaded onto tanks for hauling downstream for release at the Umatilla River boat ramp. Other adults captured incidentally at Westland, such as spring Chinook, are hauled upstream to natural production areas.

Task 4.3 - Westland Juvenile Hauling

With the UBP flow enhancement program in place, spring flows are usually high enough that most juveniles are bypassed at Westland. Trapping only occurs at the very end of the outmigration season and the biomass of juveniles captured is very low. During periods when these low numbers of fish are being captured, the fish are manually loaded onto the transport trailers by dipnet.

Juvenile trapping and transportation requirements are based on flow criteria from the 1981 USFWS study and past observations of juvenile outmigration in the Umatilla River. Downstream migrants are generally trapped and hauled in coordination with tapering off of enhancement flows. Trapping of juvenile will continue until daily trap composition is such that non-migrants out number migrants.

The same transport units used for adults are used for hauling juveniles. ODFW liberation protocols are also used as the basic guideline for juvenile hauling operations. Data collected for each transport includes date, transport unit, number of pounds hauled, 
and an estimate of mortality. Umatilla Hatchery Satellite Facility Project personnel collect information related to smolt outmigration such as size and species composition.

All juveniles are to be released at the Umatilla River boat ramp. If the WEID pumps are operating during the period when fish are being hauled from Westland, juveniles will be released into the Columbia River as near to the mouth of the Umatilla River as is logistically feasible. If non-migratory salmonids out number migrants then juveniles will be released back into the river at Westland Canal and not hauled downriver.

Task 4.4 - Threemile Dam Juvenile Hauling

The capability exists at the Threemile Dam west bank juvenile facility to trap and haul only small numbers of outmigrants. Fish are to be hauled when Phase I exchange flows and flow augmentation efforts are discontinued. If coordinated with trap operations at Westland Canal, few smolts are present above Threemile Dam when trapping operations begin. Any juveniles hauled from the facility are released at the Umatilla River boat ramp. Release site will be dependent upon operation of the WEID pumps as stated above.

Task 4.5 - Other Hauling Operations

Fish Passage Operations personnel and equipment are available for other transportation needs related to CTUIR fisheries restoration programs as long as project priorities do not preclude participation. The AOP has identified up to 1,000 fall Chinook adults for transfer from Ringold Springs Hatchery to the Umatilla River for natural spawning augmentation with releases to occur at Yoakum (RM 37) and/or Barnhart (RM 44).

In addition, the project typically hauls spring Chinook adults from Threemile Dam on an annual basis to the South Fork Walla Walla facility for outplanting. The number hauled is dependent on the size of the run to the Umatilla River based on the spring Chinook disposition table in the AOP.

\section{Objective 5 - Coordination of Passage Program}

Task 5.1 - Passage Facility Operation and Maintenance Oversight

The physical passage portion of the program includes juvenile fish screens, bypasses, and adult ladders. Operation of passage facilities are coordinated with the Umatilla Basin Fish Facility Operation and Maintenance crews using criteria developed by National Oceanic and Atmospheric Administration Fisheries (NOAA Fisheries - formerly National Marine Fisheries Service) as a general guideline for facility operations.

Task 5.2 - Management of McKay Fish Flow Releases

As part of the UBP Phase II exchange program, a portion of the water stored in McKay Reservoir is designated for fish enhancement purposes. In the spring, OWRD and BOR produce a "Beginning Storage Report" for McKay Reservoir which identifies the 
amount of water available in the reservoir for fisheries uses for that specific year. The project then allocates the release of this water using the timing and flow quantity prioritization guidelines outlined in the AOP.

\section{Task 5.3 - Coordination of Exchange Program}

There are two components of the fish passage program in the lower Umatilla River; flow enhancement and physical passage facilities. It is essential that operation of these components is coordinated with river conditions and diversion activities in order to maximize lower river migration conditions.

The UBP flow enhancement program has two components. Phase I of the UBP is comprised of a live flow exchange with West Extension Irrigation District (WEID). Phase II of the UBP has three individual components; live flow exchanges with both Hermiston (HID) and Stanfield (SID) irrigation districts and a reservoir storage exchange with SID. In all components of the UBP, Columbia River water is pumped from the McNary pool to the affected irrigation district in "exchange" for that district leaving natural Umatilla River flow instream.

Operation of this complex exchange program is coordinated by the project in conjunction with other CTUIR and ODFW staff, BOR, OWRD, and the affected irrigation districts. Criteria for operation of the flow enhancement program is based on a combination of project observations of adult and juvenile migration, UBP target flows (BOR 1988), and USFWS (1981) minimum flow recommendations. 


\section{RESULTS}

\section{Objective 1 - Passage Conditions Monitoring}

Task 1.1 - Monitoring of River and Channel Conditions

Water temperature and flow, measured at the Umatilla gauging station, exhibited extreme seasonal variation throughout the project year. The lowest daily temperature recorded at the Umatilla gauging station was $4.49^{\circ} \mathrm{F}\left(40.09{ }^{\circ} \mathrm{F}\right)$ on January 21,2008 . The lowest daily temperatures recorded by the field recorder in the east ladder at Threemile Dam was $0^{\circ} \mathrm{C}\left(32.0^{\circ} \mathrm{F}\right)$ for three days starting on January 23,2008 . The highest daily temperature was $16.18{ }^{\circ} \mathrm{C}\left(61.13^{\circ} \mathrm{F}\right)$ at the UMAO site on August 23, 2008 while the highest temperatures recorded by the field recorder was $78{ }^{\circ} \mathrm{F}$ for two days in August (August 29 and August 30). Flows at the Umatilla gauging station ranged from $92 \mathrm{cfs}$ on July 27, 2008 to 2,833 cfs on April 15, 2008.

Umatilla River flows at Dillon are affected by McKay Reservoir storage releases, irrigation withdrawals and natural flows. Flows at Dillon ranged from a low of $33 \mathrm{cfs}$ on August 23, 2008 to a high of 4,633 cfs on April 14, 2008. Flows at Yoakum ranged from 119 to $3,729 \mathrm{cfs}$ and flows at Pendleton ranged from 39 to $5,139 \mathrm{cfs}$.

River channel conditions influence the ability for passage facilities to operate within established or designed criteria. Field observations concluded that passage conditions were adequate over the project year with one exception, Feed Dam. Over the last few years, the project has observed significant down cutting below the Feed Canal ladder that has resulted in a less than adequate passage conditions at the Feed Dam.

Task 1.2 - Inspection of Passage Facilities

Seven main operational concerns were observed during monitoring of the juvenile and adult passage facilities; operational problems associated with icy conditions at Feed Canal and Threemile Dam, gravel deposition within the ladder at Westland Canal, and aquatic vegetation growth in the Threemile Dam forebay, Maxwell Canal, and Stanfield Canal. Also, the down cutting at the Feed Canal ladder has created operational issues related to passage criteria. A number of smaller problems were also noticed and corrected at the various sites.

\section{Objective 2 - Operation of Adult Trapping Facilities}

Task 2.1 - Threemile Dam Adult Trapping

Threemile Dam east bank trap operated through the project year with the exception of a week in the winter. The adult trap was closed for seven days in January to limit operational issues associated with extremely icy river conditions. 
Typically starting December 1 , the adult facility is generally closed for nine day periods followed by five days of trapping as outlined in the AOP. However, due to passage issues at Feed Dam trap and haul was initiated on December 7, 2007. Trap and haul was discontinued on March 14 and volitional migration was initiated on March 15 due to improved passage conditions at Feed Dam. In the spring, the schedule was modified based on broodstock and data needs. During the periods when the adult facility was closed, the lead gate was pulled from the ladder in order to allow volitional upstream migration of adults and enumeration occurred by video counting. The adult facility was operated on this schedule until April 20, 2008 when full time trapping was restarted so spring Chinook adults could be collected for broodstock and outplant goals.

The adult trap was turned off from May 22 through May 31 due to broodstock collection goals being met. All fish not taken for broodstock were released at Threemile Dam until June 10. Beginning June 10, all adults were hauled upstream. The adult trap was closed on July 11 and the V-trap was installed in the ladder. Threemile Dam east bank ladder remained open through the summer of 2008 due to the continued operation of Phase I through the summer. Full time trapping continued through the summer utilizing the $\mathrm{V}$-trap and the video to assess fish presence without dewatering the ladder.

The first steelhead of the 2007-08 return year was enumerated on June 7, 2007. The first returning adult salmon was recorded on September 4, 2007. A total of 3,133 summer steelhead; 1,487 adult, 1,067 jack and 999 subjack fall Chinook; 5,140 adult and 150 jack Coho; and 2,009 adult, 517 jack and 128 subjack spring Chinook were counted at Threemile Dam. In addition, there were 3 summer steelhead captured prior to initiation of the fall trapping season that were designated as 2008 brood which will be included in the 2008/09 return summary. In addition, there were 18 kelts observed at Threemile Dam during video enumeration.

Of the adult returns, 741 summer steelhead; and 640 adult and 11 jack spring Chinook were counted by video as they passed through the east bank ladder. All other adults were enumerated during trapping operations at the east bank adult facility. The west bank adult facility was not operated again this year. Appendix B contains a daily record of adults enumerated during 2007-2008.

Summer steelhead were enumerated from June 7, 2007 to May 17, 2008. The peak return occurred during March when $37.0 \%$ (1,158 of 3,133 fish) of the total return was counted. Approximately $69.9 \%$ of the run were estimated to be unmarked fish. Based on historical fork length data, $50.2 \%$ of the summer steelhead run was comprised of S1 fish and $49.8 \%$ were S2 fish.

Coho were enumerated from September 16, 2007 to December 8, 2007. Peak return month for adults was November when 58.3\% (2,995 of 5,140 fish) of the adults were enumerated. Peak month for jacks was October when 68.7\% (103 of 150 fish) of the jacks were counted. 
Fall Chinook were enumerated from September 4, 2007 to December 14, 2007. Peak return month for adults, jacks, and subjacks was October. Of the total return, $70.2 \%$ (1,045 of 1,487 fish) of the adults, $78.8 \%$ (841 of 1,067 fish) of the jacks and $86.5 \%$ (866 of 999 fish) of the subjacks were counted in October.

Spring Chinook were enumerated from April 9 to August 11, 2008. Peak month for both adults and jacks were May when $87.7 \%$ (1,761 of 2,009 fish) adults and 64.4\% (333 of 517 fish) jacks were counted. A total of 128 spring Chinook subjacks were observed at Threemile Dam. All but two were observed in July.

In addition to capturing adult salmonids, thousands of non-game fish were collected at the east bank facility during trapping operations. Major species collected were northern pikeminnow (Ptychocheilus oregonensis), chiselmouth (Acrocheilus alutaceus), and suckers (Catostomus spp.). Northern pikeminnows were sacrificed; all other non-game fish were released upstream of the dam. Juvenile salmonids and rainbow trout also entered the adult trap and were released back to the river. Other species encountered at Threemile Dam included smallmouth bass (Micropterus dolomieui), and whitefish (Prosopium williamsoni). There were no bull trout (Salvelinus confluentus) observed during trapping operations at Threemile Dam this project year.

Task 2.2 - Westland Adult Trapping

There were no kelts observed during trapping this project year.

\section{Objective 3 - Operation of Juvenile Trapping Facilities}

\section{Task 3.1 - Westland Juvenile Facility Operation}

Westland Canal was in operation for a total of 158 days between February 11 and July 18,2008 . The juvenile facility operated in the bypass mode for 150 days and in the trapping mode for 6 days. There was also 2 days when fish were directed into and held in the canal forebay between the time the bypass was closed and the trap opened.

Westland Canal opened for groundwater recharge deliveries on February 11, 2008. Natural and enhanced river flow levels were adequate to continue operation of the juvenile bypass for downstream migration until July 11 when it was closed as fish passage flows were tapered down for the summer. The juvenile trap was opened on July 13 and hauling began on July 14. Trap and haul operations continued until the facility was closed July 18.

Flow enhancement releases from McKay Reservoir and direct stream releases resulted in relatively low numbers of juvenile salmonids being captured at the Westland facility in 2008. Non-game and warmwater fish were also collected at Westland, major species included northern pikeminnow, chiselmouth, suckers, and redside shiner (Richardsonius balteatus). 
Task 3.2 - Threemile Dam Juvenile Facility Operation

The facility remained closed until the canal headworks and juvenile bypass were opened in conjunction with irrigation deliveries on March 11, 2008. The Threemile Dam west bank juvenile facility was not operated for outmigration sampling by the ODFW Umatilla Juvenile Salmonid Outmigration Project this year. The bypass was operated at 30 to $35 \mathrm{cfs}$ all year.

\section{Task 4 - Adult and Juvenile Transportation}

Task 4.1 - Threemile Dam Adult Hauling

Upstream transportation of spring Chinook and summer steelhead from Threemile Dam began on December 7, 2007. There were a total of 86 adult and 84 jack spring Chinook and 1,442 2007-08 brood summer steelhead hauled upstream this year. In addition, there were three 2008-09 brood summer steelhead hauled upstream this project year. No fall Chinook or coho were hauled again this year.

There were 878 adult and 43 jack fall Chinook transferred to the Threemile Dam Fall Chinook Holding and Spawning Facility for broodstock. In addition, 110 summer steelhead were hauled to Minthorn for brood and 560 adult and 28 jack spring Chinook were transported to the South Fork Walla Walla Spring Chinook Holding and Spawning Facility for brood. There were also a total of 241 adults and 15 jack spring Chinook transported to the South Fork facility for outplanting efforts in the Walla Walla River.

There were 144 loads of fish transported by the project from Threemile Dam on 125 days during 2007/2008. The 3,500 gallon tanker was used on 32 trips and the 3,000 gallon tanker was used for 19 trips. The CTUIR 370 gallon trailer unit was used for 79 trips and the ODFW 370 gallon trailer unit was used for 14 trips. The 750 gallon flatbed mounted tank was not used this year.

Summer steelhead adults were hauled upstream from Threemile Dam on 56 days between June 7, 2007 and July 25, 2008. There were also 31 trips made to Minthorn holding pond with brood between September 24, 2007 and April 11, 2008. Spring Chinook were hauled upstream from Threemile Dam on 15 days between June 10 and July 24, 2008. There were also 39 trips made to the South Fork facility between April 24 and June 18, 2008 with spring Chinook broodstock and adults for outplanting.

Four upriver release sites were used during 2007/2008, Stanfield Ladder (RM 32.5) Barnhart (RM 42), Thornhollow (RM 73.5), and Bear Creek (RM 87). In addition, summer steelhead adults were released below Feed Ladder (RM 29.2) to assist in the evaluation of passage at Feed Dam. Adult transport information, including dates, temperatures, liberation units used and release sites is included in Appendix C. 
There were 756 summer steelhead; 609 adult, 1,018 jack and 979 subjack fall Chinook; 5,036 adult and 144 jack Coho; and 477 adult, 200 jack and 125 subjack spring Chinook that were trapped and subsequently released into the forebay at Threemile Dam. A total of 741 summer steelhead and 640 adult and 186 jack spring Chinook volitionally migrated upstream through the east bank fish ladder.

Summer steelhead adults were trapped and released into the forebay at Threemile Dam on 90 days between September 4, 2007 and May 15, 2008. Fall Chinook were released at Threemile Dam on 77 days between September 4, 2007 and December 14, 2007. Coho were released at Threemile Dam on 69 days between September 16, 2007 and December 7, 2007. Spring Chinook were released at Threemile Dam on 50 days between April 9 and June 8, 2008.

Typically, volitional migration occurs on a regular schedule from December 1 to April 15 of each project year. However, due to passage concerns at Feed Dam, trap and haul was implemented in December and operated until flows increased in March. Radiotelemetry data showed fish passing at Feed Canal Dam at a variety of flows and temperatures. Summer steelhead were counted volitionally passing the Threemile Dam ladder on 27 days from March 15, 2008 to April 20, 2008. Spring chinook were counted volitionally passing the Threemile Dam ladder on 13 days from April 14 to May 31, 2008. Table 2 includes release location and number by species.

Table 2. Number Of Adults Released At Each Location in 2007-2008.

\begin{tabular}{|l|c|c|c|c|c|}
\hline \multicolumn{1}{|c|}{ Release Site } & $\begin{array}{c}\text { Total } \\
\text { Released }\end{array}$ & $\begin{array}{c}\text { Summer } \\
\text { Steelhead }\end{array}$ & $\begin{array}{c}\text { Spring } \\
\text { Chinook }\end{array}$ & $\begin{array}{c}\text { Fall } \\
\text { Chinook }\end{array}$ & Coho \\
\hline Bear Creek & 9 & 5 & 4 & 0 & 0 \\
\hline Thornhollow & 3 & 2 & 1 & 0 & 0 \\
\hline Barnhart & 1,192 & 1,025 & 167 & 0 & 0 \\
\hline Stanfield Ladder & 388 & 388 & 0 & 0 & 0 \\
\hline Feed Ladder & 22 & 22 & 0 & 0 & 0 \\
\hline SFWW Brood Pond & 588 & 0 & 588 & 0 & 0 \\
\hline SFWW Outplants & 256 & 0 & 256 & 0 & 0 \\
\hline Minthorn Brood Pond & 110 & 110 & 0 & 0 & 0 \\
\hline 3MD Brood Pond & 921 & 0 & 0 & 921 & 0 \\
\hline 3MD Forebay - Volitional & 1,567 & 741 & 826 & 0 & 0 \\
\hline 3MD Forebay- Trapped & 9,344 & 756 & 802 & 2,606 & 5,180 \\
\hline Total & 14,400 & 3,049 & 2,644 & 3,527 & 5,180 \\
\hline
\end{tabular}

Task 4.2 - Westland Adult Hauling

There was no summer steelhead kelts observed during trap operations this year. There were no spring chinook fallbacks hauled from Westland this year. 
Task 4.3 - Westland Juvenile Hauling

McKay water releases, direct stream releases of juveniles, and extended spring flows limited the number of juveniles captured at Westland in 2008. There were five loads of fish transported by the project from Westland trap on 5 days from July 14 to July 18, 2008. The CTUIR 370 gallon trailer unit was used for all 5 trips. An estimated 64 pounds of fish were hauled from the facility. Of these, there were an estimated 16.5 pounds of salmonids (25.8\%). The unique high water conditions present during this time, and the assumption that fish water would be available and flowing past Westland Dam all summer, provided opportunity to make decisions regarding fish disposition that were not generally supported by AOP guidelines.

On the first day of transport, the load was comprised primarily of outmigrant fall Chinook juveniles. Juveniles were hauled to the Columbia River and released under the I82 Bridge. The next two days, the fish were segregated into two groups, out-migrants (fall Chinook) were hauled to the Columbia River release site and non-migrants (sub-yearling Coho) were transferred in 5 gallon buckets with aerators and released below Westland Dam. For the fourth and fifth days of transport, all fish were released comprised of mostly outmigrants were released at the Umatilla boat ramp. Juvenile transportation information is located in Appendix D. Juvenile transportation information is located in Appendix D.

Task 4.4 - Threemile Dam Juvenile Hauling

No juveniles were trapped and hauled by the project from the Threemile Dam west bank juvenile facility during the project year.

Task 4.5 - Other Hauling Operations

No fall Chinook adults were hauled to the Umatilla River for natural spawning augmentation this project year. The project was involved in the Walla Walla spring chinook outplanting program. The project hauled 241 adult and 15 jack spring Chinook from Threemile Dam to the South Fork facility. The fish were hauled in 10 trips between May 3 and May 22, 2008. Transport information for the efforts listed in this section is included in Appendix C. The 3,500 gallon tanker unit was used on the five days and the 3,000 gallon unit was also used for five days of transport.

\section{Objective 5 - Coordination of Passage Program}

Task 5.1 - Passage Facility Operation and Maintenance Oversight

The project coordinated with Umatilla Basin Fish Facility Operations and Maintenance personnel on both daily operations and facility maintenance of ladder and screens sites throughout the project year. 
Task 5.2 - Management of McKay Fish Flow Releases

As part of the UBP Phase II exchange program, a portion of the water stored in McKay Reservoir is designated for fish enhancement purposes. Releases of fish storage water began on August 31, 2007 at 50 cfs and were increased to 75 cfs on September 17. Flow releases continued at that level through October 1 . Flows were increased from $75 \mathrm{cfs}$ on October 1 to $100 \mathrm{cfs}$ and remained at that level until November 19 when releases were reduced by 25 cfs per day until releases reached $10 \mathrm{cfs}$ on the afternoon on November 21. Flows remained at that level to maintain a minimum flow level of $10 \mathrm{cfs}$ through the winter and spring to sustain juvenile production in the lower McKay Creek.

In the spring, fish storage releases were started on June 25,2008 . The quantity released was determined by the amount needed, in conjunction with live flow exchanges, to maintain a minimum of $150 \mathrm{cfs}$ at the Dillon gauge. Flows were tapered down at a rate of $25 \mathrm{cfs}$ per day from $150 \mathrm{cfs}$ on June 25 to $50 \mathrm{cfs}$ on July 12, 2008 and remained at that level through the summer.

\section{Task 5.3 - Coordination of Exchange Program}

Phase I of the UBP was started May 7, 2007 to increase flows for returning adult Pacific lamprey. It was operated until October 26, 2007 when the exchange with WEID was discontinued in conjunction with the end of the WEID irrigation season. The exchange restarted June 24, 2008 and continued through the summer.

The Phase II exchange with HID began December 4, 2007 and ran off and on as needed to maintain UBP target flows until May 22, 2008. The SID Phase II exchange was initiated June 20, 2008. Initially, water was pumped to SID in exchange for live flow. Pumping continued through the summer in exchange for SID storage water in McKay Reservoir to be used for fish passage releases. 


\section{DISCUSSION}

\section{Task 1 - Passage Conditions Monitoring}

\section{Task 1.1 - Monitoring of River and Channel Conditions}

The project has utilized temperature data for the lower river from the BOR Hydromet UMAO station. Last year, there were significant discrepancies between the temperatures recorded by a hand held thermometer at Threemile Dam and those recorded at the UMAO gauge site. In an effort to ensure water temperatures are accurately recorded and are more reflective of passage conditions at the mouth, the project installed a field recorder at the Threemile Dam east bank ladder in October 2007.

Data were compared for periods when temperatures exhibited the highest fluctuations. Typically, these dates occur in January and February when river temperatures approach freezing and in July and August when high temperatures can be lethal for salmonids. The UMAO site reported a low of $40.09^{\circ} \mathrm{F}$ on January 21 , while the field recorder stationed in the east ladder at Threemile Dam reported a mean temperature of $33^{\circ} \mathrm{F}$ on that same day. The highest recorded temperature of $61.13^{0} \mathrm{~F}$ at the UMAO site was on August 23, while the field recorder at Threemile Dam had a mean temperature for August 23 of $70.6^{\circ} \mathrm{F}$. The temperature difference between the two sites is indicative of the sensor at the UMAO site being housed inside the station where it is partially insulated from air temperature effects. The BOR plans on repositioning the sensor outside of the housing at the UMAO gauge. The project plans on purchasing and/or borrowing a field recorder to be permanently placed in the east ladder Threemile Dam.

Between natural flows and the fish enhancement flow releases, flows were continuous from Threemile Dam to the mouth throughout the project year. However, high temperatures in the summer at the UMAO gauging station suggest that the exchanged amount of water available below Threemile Dam may not provide thermal refuge for salmonids in the lower Umatilla River.

The accuracy and timeliness of flow data from the Hydromet gauging stations continues to be sufficient for most passage decisions. Rating of the gauging stations was generally performed in a timely manner. Gauging stations were generally rated prior to the initiation of McKay storage releases making it easier to follow protected enhancement flows.

The Dillon gauge site continues to be the most important location for making fish passage decisions due to the fact, that it is located downstream of the major diversions and at what is generally the low flow point of the river. Decisions of when to implement UBP exchanges, when to augment stream flows for passage, whether to trap or bypass smolts, where to release adults, how to operate fish passage facilities, and at what flows adults and juveniles can effectively migrate are all made based on information from this gauging 
station.

There continue to be concerns associated with the best location for a gauge site that will accurately account for flow at Threemile Dam. The number of return flows and irregular channel characteristics below Threemile Dam limit the ability to accurately depict the actual flow available at Threemile Dam. An additional site (UMTO) located approximately 1.4 miles upstream of Threemile Dam was established November 2007. The site will need to have operated for at least a year in order to develop a rating curve for the site. OWRD will continue to utilize both sites for comparison in order to better assess the amount of water available for both WEID and fish passage at Threemile Dam.

Task 1.2 - Inspection of Passage Facilities

Seven main operational concerns were observed during monitoring of the juvenile and adult passage facilities; operational problems associated with icy conditions at Feed Canal and Threemile Dam, gravel deposition within the ladder at Westland Canal, and aquatic vegetation growth in the Threemile Dam forebay, Maxwell Canal, and Stanfield Canal. Also, the down cutting at the Feed Canal ladder has created operational issues related to passage criteria. A number of smaller problems were also noticed and corrected at the various sites.

This year, efforts were made to prevent operational issues at the Feed screens and the canal was shut down from January 22 through February 6 due to icy conditions in order to prevent structural damage to the drum screens. At Threemile Dam, trap and haul operations were discontinued from January 22 through January 28 when the trap was turned off due to extremely icy conditions that could have resulted in significant damage to the facility. At the time the trap was turned off, all fish were held in the ladder until the trap was turned back on and conditions improved allowing the facility to operate as intended. The project continues to recommend either shutting down or reducing irrigation diversions a couple days in advance of anticipating extremely cold weather.

Aquatic vegetation in irrigation canals continues to be a major problem for both irrigation districts and fish passage. The district's have discontinued the use of aquatic herbicides upstream of the screens and have to rely on mechanical means to contain this growth which is not nearly as efficient. This year, Maxwell Canal became choked with weeds to a point where flows could not be maintained. The Maxwell bypass is located approximately one mile from the headworks which raises concerns with the time and distance smolts have to travel to reach the bypass. Low velocities intensify these concerns.

The Stanfield Canal was dug out and cleaned prior to watering up, and it appeared that the cleaning activity and weather conditions significantly reduced the growth and mass of aquatic vegetation observed in the canal this year. However, Stanfield continues to operate through the summer providing ample opportunity for massive growth of aquatic vegetation stretching from 50 yards below the headworks to the trashracks upstream of the fish screens. Stanfield Canal was open until August 18, when due to a large biomass of 
aquatic growth impeding the irrigation district's ability to deliver water, the head gates were closed and draw down procedures were initiated.

As fish populations grow, there may be an increase in non-migratory and sub yearling salmonids seeking refuge in irrigation diversions. The ability to effectively and efficiently remove salmonids during fish salvages is restricted by the large mass of aquatic vegetation. Electroshockers are limited due to the inability to observe stunned fish underneath the mass of vegetation at the water surface. At a minimum, managers need to understand that for fish to volitionally move out of a canal there needs to be unimpeded passage and attraction to the fish bypass. The project recommends that the canal be cleaned prior to start up and that weeds "dipped" out or removed by some other mechanical means from the canal in mid-summer to limit the buildup of aquatic vegetation.

Aquatic vegetation growth at the Threemile Dam forebay poses a start up operational issue almost every year regardless of flow and weather conditions. Upon ramping up of fish water releases from McKay from 50 to $75 \mathrm{cfs}$ on September 1, the ladder was left closed for two days in order to try and flush or remove the majority of the vegetation before the ladder was reopened. Efforts were conducted in August to remove the large woody debris and sediment that had collected at the middle crest of the dam as well as the eastern corner of the dam. The large amount of deposited material has begun to direct more debris towards the ladder exit way and fish release area during high flows. The project suggests extending the log boom a few more feet westward along the crest to alleviate some concerns with debris accumulating at the fish ladder exit way and potentially dropping off the dam into the ladder entrance pool below the dam. The project still recommends that a DSL permit need to be in place to address the potential debris deposition that occurs at each facility during the project year.

There have been passage concerns at Feed Dam since adult passage evaluations were conducted in the early 1990's. At that time, radio telemetry efforts documented that there were significant delays for spring Chinook and adult summer steelhead. These delays were likely attributed to thalweg migrations above the dam moving away from the primary passage avenue (ladder).

In August of 2007, the project reported excessive differentials coming out of the ladder due to down cutting at Feed Canal Dam and ladder. The ladder was adjusted on several occasions in order to minimize slot and entrance differentials. In an effort to split the differential the ladder was set to be operated with both the fishway and flushing sections of the ladder open. The differential out of the ladder was reduced to approximately 1.5 feet, however, differentials in the ladder continued to exceed the designed 1.5 foot criteria. These adjustments were done when river flows ranged from a low of $83 \mathrm{cfs}$ in September to a high of $222 \mathrm{cfs}$ in mid-November, while temperatures ranged from a high of $70^{\circ} \mathrm{F}$ in September to a low of $40^{\circ} \mathrm{F}$ in November.

In September, HID placed rip rap and gravel along the toe of the dam to try and stabilize the dam footings. The material was loosely placed leaving many gaps and 
voids immediately downstream of the dam's deck. Unfavorable passage conditions at the ladder, encouraged fish to search out other routes leading to further delays and possible physical damage to fish attempting to pass the site. There were also concerns that the large size of the voids would allow fish to become entrained further compounding issues at the site. As the peak migration for fall Chinook and Coho approached the number of fish observed below the dam increased. Adults were observed jumping at the ladder without success.

For the past few years, there have been two passage routes fish may have utilized to pass the Dam. As mentioned above, thalweg migrations have altered passage routes selected by adults. The primary avenue has switched from being the ladder to the open slot section between the canal headworks and ladder. This route appeared to be effective in passing fish, however, in an effort to stabilize the bank. HID placed large boulders along the bank eliminating a "resting" area below the slot for fish to rest prior to negotiating the slot section.

In late November and December 2007, large numbers of adult Coho and fall Chinook were observed below Feed Canal Dam and ladder. Adults were observed jumping at the ladder entrance, and attempting to pass through the open flash board slots as well as on the deck of the Dam on the left bank. Higher than normal numbers of Coho adults were observed spawning in the tail out of the pool approximately 100 yards downstream of the dam. At very low river flows (150 to $300 \mathrm{cfs}$ ) small numbers of adults were observed successfully passing through the open flash board section in the dam. At higher flows few or no adults were observed passing either the ladder or the flash board slots. Excessive velocities and a limited "resting" pool below the slot sections appeared to be the cause of impeded passage through the area between the canal headworks and ladder.

As the fall adult return season came to an end, efforts were made to reduce the need for trapping and hauling the remainder of the adult summer steelhead returns. On December 3, boulders were placed below the apron of the dam and the open slot section. This work was aimed at building up the elevation of the tail water in an effort to reduce velocities and create a pool for fish to rest prior to passing through the open slot section of the dam.

Adjustments continued to be made to minimize slot and entrance differentials in the ladder. Thirteen adult summer steelhead were directly released below the ladder on December 20 to assess fish passage at the site. ODFW installed an underwater camera in the ladder to assess whether fish were utilizing the ladder. The video camera did not record any of the 13 hatchery adult summer steelhead released below the ladder.

In January, the project received collaborative assistance from the Pacific lamprey project and on January 3, 2008 the lamprey project installed radio telemetry equipment at the Feed Dam. There were four receivers installed at Feed Dam at four different positions in order to evaluate passage routes used, timing and possible delays. 
Receiver one was positioned to monitor fish activity downstream of the ladder, receiver two monitored activity within the ladder, receiver three monitored activity at or near the fish passage notch, and receiver four monitored activity upstream of the dam.

Following the equipment installation, four adult summer steelhead were radio tagged at Threemile Dam and released on January 9 below Feed Ladder to assess fish passage at the site. The first download was done on January 14; three of the four radio tags were detected by the approach antenna. None of these fish attempted to enter the ladder or the open slot section according to the telemetry data. A possible explanation for a fish being undetected was that the fish dropped out of range or the battery of the radio tag faded. Four days later, only 2 out of the 4 radio tags were being detected by the approach antenna and none of those fish attempted to pass the site. Again, those undetected fish may have dropped out of range or the battery of the radio tag may have faded. The lack of detections or movement during this time may have also been attributed to the extremely cold weather conditions during the last half of January or that these fish may have spit the radio tag out within the proximity of the approach antenna range.

Radio telemetry work continued from January into May. In February, there were no detections of fish passage on the underwater camera in the ladder. By the end of February, the project tagged a total of nine hatchery summer steelhead at Threemile Dam and released them below Feed Ladder. Of the four fish radio tagged in January, one was re-detected and passed by the dam using the slot on February 10 . The last date the approach antenna detected any of the remaining fish released in January was on February 19.

There were two separate release groups in February, three fish on February 11 and two on February 28. Analysis of the radio telemetry information conveyed that all the radio tagged fish in February used the slot to pass the site. Only one of the fish that had passed the dam attempted to pass the ladder. Fish in the first release group passed the dam at times ranging from 6 hrs to 12 days after release at flows ranging from 277 to $604 \mathrm{cfs}$. Both fish from the second release group passed within 2 hours of release at a flow of $835 \mathrm{cfs}$.

One concern regarding these results was that tagged fish released in early January and February took a long time (in some cases $30+$ days) to finally pass the site. However, radio telemetry studies conducted from 1994 to 1996 documented that only four out of the 43 radio tagged fish released at Threemile Dam forebay passed Feed Dam before the first half of February, giving us biological support that the delay in movement was not because of passage problems, but due to physiological requirements of steelhead that preclude them from traveling upstream when flows are low and temperatures are cold. In addition, data collected during the earlier studies showed an average passage rate of 56.8 hours at a flow ranging from 450 to $2561 \mathrm{cfs}$ and temperatures ranging from $38^{\circ}$ to $56^{\circ} \mathrm{F}$.

Using this current and historical data, the project made the decision that if flows 
continued to be above $277 \mathrm{cfs}$ below Feed Dam for at least 30 days post release from Threemile Dam, then the project would release all fish at Threemile Dam and discontinue trap and haul operations for summer steelhead.

As video review, radio-telemetry, and visual monitoring continued so did changes to the ladder. Excessive differentials inside the ladder and at the ladder entrance were observed throughout February and March which may have contributed to the inability for fish to pass using the ladder. During the late winter and early spring, there were discussions regarding completely closing off the ladder in an attempt minimize any damage that might be occurring to adults that were unsuccessfully attempting to pass the ladder. There were also discussions of building a jump pool on the apron of the dam below the slot section. It was thought that the jump pool could have been constructed at flows ranging from 500 to $600 \mathrm{cfs}$. Neither of these alternatives was implemented and radio telemetry showed that summer steelhead were successfully passing the dam utilizing the slot.

Trap and haul of all returning adult summer steelhead continued until March 14, 2008 when the trap was shut down and volitional passage and video enumeration began on March 15, 2008. From March 15 to April 20, the adult trap was operated on a nine days off and five days on schedule. By the end of March, five additional summer steelhead were implanted with radio tags bringing the total tagged to 22 adult summer steelhead.

To further assess passage at Feed Dam, spring Chinook were radio tagged in April and May. Rich Pastor with the Bureau of Reclamation helped find 28 additional radio tags to be used for the spring. In addition, it was suggested that a few summer steelhead be radio tagged at the tail end of their return season to possibly reflect timing to Feed Dam and other passage evaluations. The project utilized 22 out of the 28 radio tags by the end of April. Thirteen were put into steelhead and nine were inserted into spring Chinook. As of May 2, seven tagged fish were detected at Feed Dam (4 STS and $3 \mathrm{CHS}$ ) and both species of fish showed the ability to make it past Feed Dam without significant delay with flows over $300 \mathrm{cfs}$ this year. In addition, to monitoring passage at Feed Dam, CTUIR personnel installed additional radio tracking antennae at both Westland and Dillon Dams in order to get a broader picture of how the fish are moving through the system.

In summary, the project inserted all of the available 28 radio tags into returning adults (13 into steelhead and 15 into spring Chinook). No adult summer steelhead were observed at the Dillon telemetry site in May, while two of 13 radio tagged steelhead were detected at Westland. Interestingly, both of these fish took 6 days to reach Westland Dam from the date of release into the Threemile Dam forebay. None of these fish were detected at Feed Dam.

Spring Chinook tagging in April and May was aimed at assessing the first part of the run timing to Feed Dam. Due to channel characteristics at Dillon, it appeared that both species tagged had the ability to bypass the approach antenna located at the dam. 
One of these detected spring Chinook was picked up on the exit antenna but not on the approach, so there is very little information regarding the actual time it took for a specific fish to pass the site. The information we do have is that one of these fish passed the site in 11 minutes; the information for the other three is unavailable. On average it took 10.25 days to reach Dillon Dam from release at Threemile Dam. There were three radio tagged spring Chinook detected at Westland in May. All detections at Westland were recorded by the approach antenna. On average it took 18 days to reach Westland post release from Threemile Dam. There were no detections in May at Feed Dam. This may have attributed to damage done to the antennae cords along the walk way to the ladder and on the ladder.

Short-term and long term passage at Feed Dam still remains a concern. Especailly, if these strategies are to include all species and life history stages. In June, the project received drawings of the proposed short-term fish for addressing fish passage at Feed Dam. The proposed short-term fix is focused on the north bank near the ladder and includes installing four rock weirs and a roughened channel. The proposed structures would provide benefit for passage through both the notch (passage notch between the ladder and headworks) and the ladder. Installing rock weirs below the apron (north bank) would raise the tail water enough for these passage avenues to be within the 1 foot drop height differential criteria for adult salmonids.

In addition, a roughened channel chute was proposed for the passage notch. The thought was that the placement of boulders in the chute would relieve velocities to a point that would favor fish passage and allow for weaker swimming species to negotiate the newly constructed chute. This work is planned for the fall of 2008 prior to the peak fall adult up-migration. However, there are several concerns that this short term fix will not achieve $100 \%$ passage of all species and life history stages.

A high flow event on April 13 through April 16 created a large log jam at the Westland Ladder. Operation and maintenance crews and ODFW and CTUIR personnel cleared the debris on April 16.

The project is working with the NOAA and O\&M personnel in identifying limiting factors associated with gravel entrainment within the Westland ladder. Over several years, there have been operational issues associated with Auxiliary Water Supply (AWS) resulting from entrained gravel not allowing for proper operation of the attraction gate. This gate is hydraulically controlled and is responsible for providing attraction flows to the ladder entrances. In 2006, the O\&M project installed a smaller mesh screen on the outside of the AWS trash racks to reduce the amount and size of substrate that built up behind the AWS attraction gate.

For the last two years, it appears the smaller screen mesh has significantly reduced the amount and size of the material in the AWS. The material behind the gate appeared to be comprised mostly of fine sediment. However, two things hindered a good evaluation of the extended operation and the ability to operate the AWS within criteria. First, it was a good water year, which delayed installation of the flash board section until the tail end of 
the adult return season and provided a good passage avenue through the site. Secondly, welds broke loose on the gate during the spring curtailing operation of the AWS. Next year the project intends to record the number of days that the AWS operated during the peak adult migration and the differential at the entrances. Also, the number of days will be noted of when the flash dam was in place and when it was not. The project plans on comparing attraction differentials during these periods. This information may illustrate the number of days the ladder operated at criteria when it was the primary passage avenue.

There continues to be a need to update the passage facilities operational criteria developed by NOAA Fisheries. Changes have been made to the criteria at a number of facilities without being formalized. It is important that these criteria be reviewed and updated.

\section{Task 2 - Operation of Adult Trapping Facilities}

\section{Task 2.1 - Threemile Dam Adult Trapping}

The Threemile Dam east bank ladder and adult facility both performed satisfactorily again during the 2007/2008 season. Few high magnitude flow events and debris loads were experienced this year which resulted in the ladder being open most of season.

Due to the passage concerns at Feed Dam, volitional migration of adults past Threemile Dam began in March rather than December as outlined in the AOP. At that time, a five day trapping/nine day volitional migration rotation was implemented. This schedule was adjusted as needed based on steelhead and spring chinook broodstock collections and CWT recoveries. Video/trapping rotations continued until April 20, 2008. At that time, continuous trapping was reinitiated due to brood collection needs. However, video enumeration was reinitiated from May 22 through May 31 due to broodstock goals being met.

As mentioned above, video enumeration did not occur in the winter and was not implemented until March. Enumeration of species and numbers during the spring using video counting was generally a success. Identification of adipose clipped versus unmarked steelhead was difficult this year. However, identification of jack versus adult spring chinook was easily done. In the past, mark identification on summer steelhead could not always be determined during low visibility periods and these steelhead were listed in the records as being of unknown origin. However, during the past couple years, marked versus unmarked ratios for steelhead have been very inconsistent between video and trapping periods regardless of visibility conditions. It now appears that lighting conditions at the site are inadequate for determined whether fish are marked, so it has been decided that all steelhead counted during the video periods will just be listed as "unknown." No attempts were made to determine sex or actual marks from the videotape. Sex ratio and mark group composition for each species were estimated from data collected during trapping operations.

In 2006, the project purchased a video software program from Salmonsoft and a 
new camera for video enumeration. The video software is a fish passage monitoring system consisting of two components. The Fish Capture (FishCap) program is used to record fish movement pass the viewing window and reduce the amount of frames when a fish is not detected. The Video Review Program allows the user to review the images recorded from the FishCap program. The equipment and software were installed in the viewing room at Threemile Dam in January 2006. Observer time was cut to half of the time it took to review analog tapes.

However, the location of the video site at the dam appears to be a limiting factor. Video compression continues to improve; however, lighting issues have persisted even with the upgraded video camera. Lighting affects the observer's ability to efficiently and accurately depict marks on fish. In an effort to counter lighting issues and uncertainties depicting marks, the video capture program was operated in conjunction with trapping operations so that the number and marks of fish in the trap could be correlated with video review. The program consistently picked up the same number of fish observed in the trap, with a few exceptions when fish appeared to be located upstream of the viewing window and have yet to enter the trap. Turbidity causes efficiency issues associated with identifying marks. In general, it took considerably longer to identify marks of fish when high turbidity was an issue. There are extended periods when poor water quality conditions persist at Threemile Dam. In addition, the warmer water temperatures at Threemile Dam accelerate the rate at which algae builds on the white background installed last summer to improve visibility of marks. The project has coordinated with the O\&M crew to maintain both the viewing window and background.

The project will work on improving lighting conditions by illuminating the entire viewing room as was done at Nursery Bridge Dam on the Walla Walla River in MiltonFreewater, OR. In addition, the O\&M crew is looking into ways to improve cleaning of the viewing window and white background. Furthermore, to ensure that the FishCap program is consistently recording all images of fish passage at Threemile Dam, the video capture program will continue to be operated in conjunction with the initiation of the trapping schedule.

The occurrence of downstream movement past the counting station appeared to be similar to past years. There was a greater proportion of adult summer steelhead movement past the window than spring Chinook. Natural timing and swimming ability of salmon to negotiate higher velocities may be the driving force behind the difference between the two species. Spring Chinook arrive at Threemile Dam with the intent of moving into the headwaters at that time while summer steelhead arrive at Threemile Dam throughout the adult return season and passage spikes with high flows. Spring Chinook appear to move through the facility with more ease than summer steelhead which may have attributed to the difference.

In an effort to reduce double counting of adult returns during the trapping/video rotations, the timing of the lead gate change is conducted at a low movement period (noon). Also, kelts are generally identifiable by condition. This allows kelts to be recorded separately and not mis-classified as fallbacks. Fish behavior changes dramatically when 
the diffuser grate is in place. As mentioned above, there is a behavioral difference between species which may be attributed to the physiology and timing of entrance into the system. The project will make an effort at correlating fish behavior (upstream and downstream movement) with flows, temperature, turbidity, debris loads, time of year, and over all exit way conditions. A better effort needs to be done to assess the parameters influencing exiting passage conditions.

A total of $23.7 \%$ of the steelhead run and $26.8 \%$ of the spring Chinook were video counted. The relatively high percentage of spring chinook video taped is consistent with the project objective to maximize the periods of volitional migration for both steelhead and spring Chinook. However, the passage issue at Feed Dam eliminated the rotations of video/trap weeks that were typically initiated in December and did not allow for maximum volitional migration of steelhead. In the past, the rotations allowed for a minimum of 18 days of volitional migration per month. Instead, the project had to haul returning steelhead adults above all the diversions until March. Rotations between trapping and video enumeration weren't initiated until March and were discontinued in conjunction with spring Chinook broodstock collection.

Due to the large number of fall Chinook subjacks collected the past few years, the AOP requires that only a subsample of the CWT subjacks be sacrificed. The size of the subjacks has remained consistent with the size observed the past number of years. Historically, the size range for subjacks was set at less than 15 inches $(380 \mathrm{~mm})$ but based on CWT recovery data was increased to less than 15.75 inches (400mm) in 2002.

There were few numbers of spring chinook "minijacks" captured in the Threemile Dam trap. These fish are confirmed to be from the current year releases. All the CWT subjacks were sacrificed in order to determine origin. The rest were released into the forebay at Threemile Dam. None were transported upstream. These fish were included in this year's counts and incorporated into the database.

Steelhead adults continue to be enumerated by brood year in the late spring. Prior to 2002, all steelhead captured prior to the trap being closed in the early summer were considered to be of that brood year. Since 2002, attempts have been made to segregate these late spring returning adults by brood year. Coloration and condition are used as indicators for making these brood year determinations. The run timing of summer steelhead adults appears to overlap between subsequent brood years. Advanced entry of summer steelhead adults into the Umatilla River may illustrate that these fish are taking advantage of the optimum passage conditions present in the spring due in part to the UBP flow enhancement measures during this time period.

Task 2.2 - Westland Adult Trapping

The combination of extended natural and enhanced flows the last few years have resulted in the Westland bypass being open until early summer. This allows kelts to volitionally migrate out of the system. There were no kelts captured at Westland this year. 
With the low number of juveniles being trapped at Westland and no adults being captured, the trapping facility is operated without using the separator and adult holding pond. All fish that enter the facility are trapped in the juvenile holding pond where they are more readily accessed.

\section{Task 3 - Operation of Juvenile Trapping Facilities}

\section{Task 3.1 - Westland Juvenile Facility Operations}

There were few problems at the Westland juvenile collection facility. Problems noted in earlier years with fluctuating canal forebay elevations and the bypass outfall have ceased to be a concern due to frequent sensor maintenance and increased experience in operating the automated headgate system. This year, the mass of aquatic vegetation growth appeared to be delayed due to cooler water temperatures and over all cool weather conditions. The traveling screen was operational and in place for juvenile trapping operations. However, minimal accumulation of vegetation in the holding pond reduced O\&M labor and operational concerns.

A combination of extended natural flows and flow augmentation allowed the facility to be operated in the bypass mode until July 11 . This allowed the majority of the juvenile outmigration to be bypassed at Westland. Maintaining McKay Reservoir storage releases into early summer is now the standard operating procedure. This permits Westland to be operated primarily in the bypass mode during the juvenile outmigration period and the majority of the smolts will be able to migrate volitionally. The number of juveniles trapped at Westland continues to be low and trap and haul operations are more than adequate for assisting this late outmigration component under this current scenario.

Fish passage storage releases were made at a rate necessary to maintain the 150 cfs target at Dillon Dam through July 9 . Flows were tapered at a rate of $25 \mathrm{cfs}$ per day from $150 \mathrm{cfs}$ on July 9 to $50 \mathrm{cfs}$ on July 12 and remained at that level throughout the summer. The ladder and bypass were closed July 11 as flows were reduced to minimize the number of juveniles below Westland Dam. The minimal depth of the spill seems to be a deterrent to juveniles. In combination with the large flow volume entering Westland Canal, most juveniles are thought to enter the canal where they can be captured.

The decision to discontinue trapping is based on the low number of salmonids in combination with a significant increase in non-salmonids. This condition is usually signaled by an increase in the poundage of fish hauled from the facility towards the end of the trapping period. This increase in poundage is almost exclusively comprised of larger sized non-salmonids. In addition, the decision also includes an assessment of the number of sub-yearling coho and juvenile summer steelhead present in the trap which are probably rearing in this area and not migrating downstream.

Poor water quality conditions are generally observed every year during trapping at Westland. However, the low numbers of juveniles being trapped lessen the constraints of the facility and the site is adequate for current operations. 
Task 3.2 - Threemile Dam Juvenile Facility Operations

The juvenile facility was not operated and the bypass operated at $35 \mathrm{cfs}$ throughout the project year. The headworks were opened on March 11 in conjunction with WEID start up of irrigation deliveries. The optimal bypass flow this year appeared to have a significant affect on flushing juveniles out of the facility. For research purposes, there are ongoing discussions aimed at operating the juvenile facility at the optimal bypass flow of $35 \mathrm{cfs}$. It will be interesting to see if trapping operations can occur at the desired 35 cfs flow level.

\section{Task 4 - Adult and Juvenile Transportation}

Task 4.1 - Threemile Dam Adult Hauling

Project hauling equipment was generally adequate for adult transport needs in 2007/2008. The flatbed mounted, 750 gallon tanker was not used this year. The small eight inch exit ports on the trailers still require the use of the 3,500 and 3,000 gallon tanker units to haul adult Chinook salmon.

The UBP flow enhancement effort has substantially reduced the number of fish that need to be transported upstream from Threemile Dam. However, trap and haul was initiated earlier than "normal" due inadequate passage conditions at Feed Dam. Typically, video/trap rotations occur in the first week of December. However, trap and haul was initiated on December 6, 2007 and operated until March 15. During this time all adult summer steelhead were either hauled to Stanfield or Barnhart. The decision to discontinue trap and haul was supported by radio telemetry information suggesting that adult steelhead were passing at higher flows than those observed in the winter. With the exception of brood and hauling steelhead above Feed Dam, adults were only hauled from June 10 to August 26, 2008. During this period, all adults were hauled to Bear Creek and/or Thornhollow for release as per AOP criteria. Fish were either released at, or volitionally migrated past Threemile Dam the rest of the year. Condition of adults at release generally appeared good at all sites.

The use of McKay Reservoir storage releases in the fall and spring for adult passage is anticipated to continue in the future for all but the driest years. This will permit the majority of adults to migrate volitionally. The number of adults requiring transportation on an annual basis should continue to remain low under this operating scenario.

As noted in past annual reports, a decision has been reached to discontinue transporting early fall returning adult steelhead, fall chinook and coho (late August/early September). Even though the 30 day, 150 cfs criteria is not met when these fish return, only small numbers are generally trapped and fall flow enhancement efforts usually increase flows to criteria levels within one or two weeks. This may be especially important with steelhead as higher numbers of out of basin steelhead have been captured in the fall since implementation of the UBP and this allows non-Umatilla origin steelhead the opportunity to migrate back out of the system. 
Barnhart was used by the project this year as a release site for summer steelhead being transported around the Feed Canal passage problem area. Modifications were made to the Barnhart site to allow tanker units and smaller transport units access, and to regulate the amount of damage being done to the property by vehicles. The site is important due to its location downstream of Birch Cr. a tributary that is highly utilized by summer steelhead adults. It appeared that anglers took the opportunity to focus fishing efforts very near to the Barnhart release site and catch rates were high. Release sites were altered from Barnhart to just above Stanfield Ladder to allow for dispersal of adults. The Stanfield Ladder site worked well as a release site and the project received verbal approval to use the site from the land owner. With the limited numbers of adults currently being hauled, the available release sites should meet project needs. This assumes that access will continue to be available at Yoakum for the release of fall Chinook adults and the Stanfield Ladder on Bork's property.

Task 4.2 - Westland Adult Hauling

No adult summer steelhead were hauled from Westland this year.

Task 4.3 - Westland Juvenile Hauling

Due to the extended flow enhancement efforts and spring flows, relatively small numbers of juveniles were trapped again this year at Westland. The use of McKay Reservoir storage releases to extend the spring/summer passage period for juveniles is anticipated to continue in the future. This will maximize instream migration of juveniles and minimize transportation. The number of juveniles requiring transportation on an annual basis should continue to remain low under this operating strategy.

The small numbers of fish being trapped at Westland eliminates the need for a fish pump; all fish are loaded using dipnets. The Pescalator fish pump is still stationed at Westland and would be available for use by another project in the Columbia Basin.

Task 4.4 - Threemile Dam Juvenile Hauling

Summer fish enhancement flows provided this year allowed the juvenile bypass to continue running all summer. The trap was not turned on and no juveniles were transported from the facility.

Task 4.5 - Other Hauling Operations

Fish Passage Operations personnel and equipment were not used in 2007 to transport fall chinook adults from Ringold Springs Hatchery or Priest Rapids Hatchery to the Umatilla River. Due to disease concerns at Priest Rapids and the number of adult fall Chinook returning to the Umatilla River a decision was made not to transport from Ringold Springs Hatchery this year. However, the project will continue to haul spring Chinook from Threemile Dam for outplanting in the Walla Walla Basin. 


\section{Objective 5 - Coordination of Passage Program}

Task 5.1 - Passage Facility Operation and Maintenance Oversight

The project coordinates with Umatilla Basin Fish Facility Operations and Maintenance personnel on both daily operations and facility maintenance of ladder and screen sites. The Umatilla Basin Fish Facility Operations and Maintenance staff is a well established crew and has been working together for a number of years. In an effort to improve coordination between the URFPO project staff and the Operation \& Maintenance personnel the projects have been meeting to discuss upcoming seasonal operations. Establishing quarterly meetings with the O\&M project has allowed both projects the opportunity to utilize invaluable experienced gained through operating fish passage facilities for a number of years. Over the last two years, better coordination amongst the two projects has improved communication of priorities and planning for upcoming passage facility operations. However, communication amongst the two projects needs to grow to the point that O\&M is balanced with fish passage benefits. Maintenance decisions need to be based on fish passage needs rather than O\&M costs.

\section{Task 5.2 - Management of McKay Fish Flow Releases}

The timing of fall McKay Reservoir fish passage flow releases remained similar to past years. Flows were initiated August 31, 2007 in coordination with the discontinuation of WID storage releases for the year in order to maintain flows in the mainstem below McKay Creek for juvenile production as well as for adult attraction and passage in the lower river.

No fall chinook adults were captured until September 4 and the first post-summer steelhead was also trapped September 4. Although Phase I continued through the summer flow releases were not initiated until August 31 . Releases started at $50 \mathrm{cfs}$ and were increased to $75 \mathrm{cfs}$ on September 17. Flows remained at that level until October 1, when flows were increased from $75 \mathrm{cfs}$ to $100 \mathrm{cfs}$ and remained at that level until November 19. Beginning on November 19, releases were reduced by $25 \mathrm{cfs}$ per day until releases reached $10 \mathrm{cfs}$ on the afternoon of November 21 and remained at that level through the winter. The flow releases, aimed at attracting early arriving salmon into the mouth of the Umatilla River, seem to have a limited affect on the time of entry for these fish. Tributary entry of all species appears to be based on inherent biological timing as long as flow and temperature conditions do not preclude entry. This factor may be most important for summer steelhead, as adults have been captured during every month for the past five project years.

Flow releases into lower McKay Creek below McKay Reservoir continued year around. Fall enhancement flows were tapered down from $150 \mathrm{cfs}$ to $10 \mathrm{cfs}$ in midNovember. A minimum flow of $10 \mathrm{cfs}$ was maintained all winter to sustain juvenile production in the stream reach. Historically, significant numbers of juvenile steelhead and Coho, as well as a few bull trout were found rearing in lower McKay Creek. Potentially, 
these winter releases could impact the ability of the reservoir to fill to capacity as it did in 2005-06 which would result in less water available for passage during critical migration periods.

This year, because of extended spring flows and the reservoir filling releases did not begin until late June and allowed for releases to continue all summer. Water was released from McKay Reservoir beginning on June 25 a month later than last year to maintain a target flow level of $150 \mathrm{cfs}$ at Dillon through July 9. Flows were tapered at a rate of 25 cfs/day from $150 \mathrm{cfs}$ on July 9 to $50 \mathrm{cfs}$ on July 12 and remained at that level all summer.

The AOP outlines priority flow timing and levels for use of stored water. Water releases during the late spring/early summer from McKay Reservoir provides both juvenile and adult passage benefits. It extends the natural upstream migration period for spring chinook and provides a longer period for volitional outmigration of both natural and hatchery fall Chinook juveniles. It also significantly reduces the reliance on artificial transportation for both adults and juveniles.

\section{Task 5.3 - Coordination of Exchange Program}

For the third consecutive year, Phase I was operated through the summer in 2008. An agreement with BPA ensured Phase I continued through the summer to provide flows in the lower river for the natural upstream migration of adult Pacific lamprey, as well as, a potential adult steelhead benefit. The project implemented video review to detect adult Pacific lamprey passage and allow the project to determine fish presence in the ladder without totally dewatering it. Video review efforts detected no adult Pacific lamprey passing through the ladder.

As mentioned in last year's annual report, there are alternate avenues that adult Pacific lamprey may use to pass the dam without being detected by video efforts. One path that allows adult Pacific lamprey passage is the diffuser structure that funnels fish towards the viewing window. The diffuser grating provides a low velocity avenue for adult Pacific lamprey to pass the ladder without passing by viewing window slot. The grates are spaced 1.5 inches apart possibly enough space to allow adult Pacific lamprey to pass undetected. In 2007, the Pacific lamprey project observed four out of the 15 radio-tagged adult Pacific lamprey that were released below the Threemile Dam passing the dam by climbing the vertical wall at the east end of the dam crest (Moser and Jackson 2007). It was also noted that three of the four that passed took over three months to pass (Moser and Jackson 2007). Currently, the Pacific lamprey project is continuing a radio tagging effort to address passage concerns in the basin. Results will be reported in the Pacific lamprey project's 2007-2008 Annual Report.

Development of an annual operating plan for the UBP continues to be useful as an operating guideline for the complex exchange program. Annual operating plans are an extremely useful tool which have been used for basin fish management decisions for many years and would provide a similar benefit for water management. 


\section{References}

Confederated Tribes of the Umatilla Indian Reservation, et al. (CTUIR, et al.). 2001. Draft Umatilla Subbasin/Willow Creek Subbasin Summary, August, 2001. Submitted to Northwest Power Planning Council, Portland, Oregon.

Confederated Tribes of the Umatilla Indian Reservation and Oregon Department of Fish \& Wildlife (CTUIR \& ODFW). 1989. Umatilla Hatchery Master Plan. Submitted to Northwest Power Planning Council, Portland, Oregon.

Confederated Tribes of the Umatilla Indian Reservation and Oregon Department of Fish \& Wildlife (CTUIR \& ODFW). 1990. Columbia Basin System Planning, Umatilla Subbasin, September, 1990. Submitted to Northwest Power Planning Council and Columbia Basin Fish and Wildlife Authority, Portland, Oregon.

Confederated Tribes of the Umatilla Indian Reservation and Oregon Department of Fish \& Wildlife (CTUIR \& ODFW). 2004. Umatilla Hatchery and Basin Annual Operation Plan, For the Period September 2004 to August 2005.

Hendricks, Paul. 2007. Oregon Water Resources Department, Umatilla River Coordinator, Personal Communication.

Moser, M.L, and Aaron Jackson. Draft. 2007. Identification of low-elevation impediments to adult Pacific lamprey (Lampetra tridentata) migration in the Umatilla River, Oregon.

Oregon Department of Fish and Wildlife (ODFW). 1986. A Comprehensive Plan for Rehabilitation of Anadromous Fish Stocks in the Umatilla River Basin. Report to Bonneville Power Administration, Contract No. DE-Al79-84BP18008, Project No. 84-10, Portland, Oregon.

U.S. Bureau of Reclamation (BOR). 1988. Umatilla Basin Project, Oregon. Planning Report - Final Environmental Statement. U.S. Department of the Interior, Northwest Region, U.S. Bureau of Reclamation, Boise, Idaho.

U.S. Fish and Wildlife Service (USFWS). 1981. Instream Flow Study of the Umatilla River. U.S. Department of the Interior, Fisheries Assistance Office, U.S. Fish \& Wildlife Service, Vancouver, Washington.

Zimmerman, B.C. and B.B. Duke. 2001. Fish Passage Operations in the Umatilla River, 2001-2002. Annual Report prepared for project No. 198802200, Intergovernmental Agreement No. DE-BI79-89BP98636. Bonneville Power Administration, Portland, Oregon. 
Appendices 


\begin{tabular}{|c|c|c|c|c|c|c|c|c|c|c|c|c|}
\hline & & & PED & & & $\mathrm{SAC} / \mathrm{I}$ & & & RELEA & UPST & & \\
\hline DATE & TOTAL & $\mathrm{AD}$ & JK & $\mathrm{MJ}$ & TOTAL & $\mathrm{AD}$ & JK & $\mathrm{MJ}$ & TOTAL & $\mathrm{AD}$ & $\mathrm{JK}$ & TOTAL \\
\hline $9-04$ & 1 & 1 & 0 & 0 & 0 & & & & 0 & & & 1 \\
\hline $9-05$ & 1 & 1 & 0 & 0 & 0 & & & & 0 & & & 1 \\
\hline $9-06$ & 1 & 1 & 0 & 0 & 0 & & & & 0 & & & 1 \\
\hline $9-10$ & 3 & 2 & 1 & 0 & 0 & & & & 0 & & & 3 \\
\hline $9-12$ & 2 & 1 & 1 & 0 & 0 & & & & 0 & & & 2 \\
\hline $9-13$ & 2 & 2 & 0 & 0 & 0 & & & & 0 & & & 2 \\
\hline $9-16$ & 3 & 3 & 0 & 0 & 0 & & & & 0 & & & 3 \\
\hline $9-17$ & 5 & 4 & 1 & 0 & 0 & & & & 0 & & & 2 \\
\hline $9-18$ & 14 & 10 & 4 & 0 & 0 & & & & 0 & & & 5 \\
\hline $9-19$ & 15 & 7 & 8 & 0 & 0 & & & & 0 & & & 8 \\
\hline $9-20$ & 6 & 5 & 1 & 0 & 0 & & & & 0 & & & 1 \\
\hline $9-21$ & 3 & 2 & 1 & 0 & 0 & & & & 0 & & & 1 \\
\hline $9-22$ & 5 & 3 & 2 & 0 & 0 & & & & 0 & & & 3 \\
\hline $9-23$ & 5 & 5 & 0 & 0 & 0 & & & & 0 & & & 1 \\
\hline $9-24$ & 14 & 8 & 6 & 0 & 0 & & & & 0 & & & 9 \\
\hline $9-25$ & 14 & 8 & 4 & 2 & 1 & & & 1 & 0 & & & 6 \\
\hline $9-26$ & 5 & 4 & 0 & 1 & 1 & & & 1 & 0 & & & 1 \\
\hline $9-27$ & 4 & 2 & 1 & 1 & 1 & & & 1 & 0 & & & 1 \\
\hline $9-28$ & 4 & 4 & 0 & 0 & 0 & & & & 0 & & & 0 \\
\hline $9-30$ & 213 & 152 & 55 & 6 & 0 & & & & 0 & & & 159 \\
\hline SEP & 320 & 225 & 85 & 10 & 3 & 0 & 0 & 3 & 0 & 0 & 0 & 210 \\
\hline $10-1$ & 45 & 21 & 18 & 6 & 2 & & & 2 & 0 & & & 18 \\
\hline $10-2$ & 62 & 27 & 23 & 12 & 1 & & & 1 & 0 & & & 30 \\
\hline $10-3$ & 40 & 16 & 18 & 6 & 0 & & & & 0 & & & 24 \\
\hline $10-4$ & 141 & 76 & 47 & 18 & 3 & & 2 & 1 & 0 & & & 66 \\
\hline $10-5$ & 77 & 33 & 28 & 16 & 2 & & 2 & & 0 & & & 44 \\
\hline $10-6$ & 54 & 15 & 24 & 15 & 3 & & & 3 & 0 & & & 37 \\
\hline $10-7$ & 45 & 17 & 12 & 16 & 2 & & & 2 & 0 & & & 41 \\
\hline $10-8$ & 56 & 18 & 16 & 22 & 3 & & & 3 & 0 & & & 35 \\
\hline $10-9$ & 78 & 23 & 27 & 28 & 3 & & & 3 & 0 & & & 50 \\
\hline $10-10$ & 81 & 29 & 25 & 27 & 0 & & & & 0 & & & 52 \\
\hline $10-11$ & 125 & 57 & 39 & 29 & 0 & & & & 0 & & & 83 \\
\hline $10-12$ & 140 & 51 & 46 & 43 & 0 & & & & 0 & & & 98 \\
\hline $10-13$ & 122 & 35 & 34 & 53 & 0 & & & & 0 & & & 101 \\
\hline $10-14$ & 80 & 38 & 11 & 31 & 0 & & & & 0 & & & 80 \\
\hline $10-15$ & 49 & 12 & 11 & 26 & 0 & & & & 0 & & & 49 \\
\hline $10-16$ & 72 & 21 & 25 & 26 & 0 & & & & 0 & & & 51 \\
\hline $10-17$ & 93 & 19 & 34 & 40 & 0 & & & & 0 & & & 75 \\
\hline $10-18$ & 84 & 14 & 34 & 36 & 0 & & & & 0 & & & 72 \\
\hline $10-19$ & 87 & 20 & 29 & 38 & 0 & & & & 0 & & & 67 \\
\hline $10-20$ & 185 & 65 & 74 & 46 & 0 & & & & 0 & & & 123 \\
\hline $10-21$ & 256 & 154 & 62 & 40 & 0 & & & & 0 & & & 154 \\
\hline $10-22$ & 75 & 26 & 18 & 31 & 1 & & & 1 & 0 & & & 62 \\
\hline $10-23$ & 130 & 42 & 32 & 56 & 0 & & & & 0 & & & 110 \\
\hline $10-24$ & 133 & 36 & 34 & 63 & 0 & & & & 0 & & & 133 \\
\hline $10-25$ & 73 & 26 & 21 & 26 & 0 & & & & 0 & & & 73 \\
\hline $10-26$ & 233 & 108 & 55 & 70 & 0 & & & & 0 & & & 233 \\
\hline $10-27$ & 61 & 22 & 17 & 22 & 0 & & & & 0 & & & 61 \\
\hline $10-28$ & 14 & 5 & 1 & 8 & 0 & & & & 0 & & & 14 \\
\hline $10-29$ & 24 & 8 & 10 & 6 & 0 & & & & 0 & & & 16 \\
\hline $10-30$ & 15 & 2 & 5 & 8 & 0 & & & & 0 & & & 12 \\
\hline $10-31$ & 22 & 9 & 11 & 2 & 0 & & & & 0 & & & 14 \\
\hline $\mathrm{OCT}$ & 2752 & 1045 & 841 & 866 & 20 & 0 & 4 & 16 & 0 & 0 & 0 & 2078 \\
\hline CUM/OCT & 3072 & 1270 & 926 & 876 & 23 & 0 & 4 & 19 & 0 & 0 & 0 & 2288 \\
\hline $11-01$ & 15 & 4 & 7 & 4 & 1 & & & 1 & 0 & & & 11 \\
\hline $11-02$ & 28 & 4 & 12 & 12 & 0 & & & & 0 & & & 24 \\
\hline $11-03$ & 17 & 3 & 6 & 8 & 0 & & & & 0 & & & 15 \\
\hline $11-04$ & 10 & 2 & 3 & 5 & 0 & & & & 0 & & & 8 \\
\hline $11-05$ & 27 & 12 & 6 & 9 & 0 & & & & 0 & & & 15 \\
\hline $11-06$ & 33 & 13 & 10 & 10 & 0 & & & & 0 & & & 20 \\
\hline $11-07$ & 32 & 10 & 17 & 5 & 0 & & & & 0 & & & 22 \\
\hline $11-08$ & 21 & 10 & 7 & 4 & 2 & & 2 & & 0 & & & 10 \\
\hline $11-09$ & 22 & 10 & 6 & 6 & 0 & & & & 0 & & & 12 \\
\hline $11-10$ & 44 & 26 & 9 & 9 & 0 & & & & 0 & & & 18 \\
\hline $11-11$ & 64 & 29 & 18 & 17 & 0 & & & & 0 & & & 38 \\
\hline $11-12$ & 24 & 13 & 3 & 8 & 0 & & & & 0 & & & 16 \\
\hline $11-13$ & 24 & 11 & 7 & 6 & 0 & & & & 0 & & & 21 \\
\hline $11-14$ & 24 & 10 & 6 & 8 & 0 & & & & 0 & & & 22 \\
\hline $11-15$ & 6 & 4 & 1 & 1 & 0 & & & & 0 & & & 4 \\
\hline $11-16$ & 2 & 1 & 1 & 0 & 0 & & & & 0 & & & 2 \\
\hline $11-17$ & 15 & 9 & 5 & 1 & 0 & & & & 0 & & & 12 \\
\hline $11-18$ & 23 & 13 & 6 & 4 & 0 & & & & 0 & & & 20 \\
\hline $11-19$ & 15 & 10 & 3 & 2 & 0 & & & & 0 & & & 9 \\
\hline $11-20$ & 22 & 14 & 4 & 4 & 0 & & & & 0 & & & 11 \\
\hline $11-21$ & 3 & 1 & 2 & 0 & 0 & & & & 0 & & & 2 \\
\hline $11-22$ & 2 & 0 & 2 & 0 & 0 & & & & 0 & & & 2 \\
\hline NOV & 473 & 209 & 141 & 123 & 3 & 0 & 2 & 1 & 0 & 0 & 0 & 314 \\
\hline CUM/NOV & 3545 & 1479 & 1067 & 999 & 26 & 0 & 6 & 20 & 0 & 0 & 0 & 2602 \\
\hline $12-03$ & 1 & 1 & 0 & 0 & 0 & & & & 0 & & & 0 \\
\hline $12-06$ & 2 & 2 & 0 & 0 & 0 & & & & 0 & & & 2 \\
\hline $12-07$ & 4 & 4 & 0 & 0 & 0 & & & & 0 & & & 1 \\
\hline $12-14$ & 1 & 1 & 0 & 0 & 0 & & & & 0 & & & 1 \\
\hline DEC & 8 & 8 & 0 & 0 & 0 & 0 & 0 & 0 & 0 & 0 & 0 & 4 \\
\hline CUM/DEC & 3553 & 1487 & 1067 & 999 & 26 & 0 & 6 & 20 & 0 & 0 & 0 & 2606 \\
\hline
\end{tabular}




\begin{tabular}{|c|c|c|c|c|c|c|c|c|c|c|c|c|c|c|c|}
\hline \multirow[b]{2}{*}{ DATE } & \multicolumn{3}{|c|}{ TRAPPED } & & /MORT & & RELEA & UPSTI & & RELE & SED @ & DAM & & 2000 & \\
\hline & TOTAL & $A D$ & $\mathrm{JK}$ & TOTAL & $\mathrm{AD}$ & $\mathrm{JK}$ & TOTAL & $\mathrm{AD}$ & $\mathrm{JK}$ & TOTAL & $\mathrm{AD}$ & $\mathrm{JK}$ & TOTAL & $\mathrm{AD}$ & JK \\
\hline $9-16$ & 1 & 0 & 1 & 0 & & & 0 & & & 1 & & 1 & 0 & & \\
\hline $9-17$ & 3 & 3 & 0 & 0 & & & 0 & & & 3 & 3 & & 0 & & \\
\hline $9-18$ & 2 & 1 & 1 & 0 & & & 0 & & & 2 & 1 & 1 & 0 & & \\
\hline $9-19$ & 2 & 1 & 1 & 0 & & & 0 & & & 2 & 1 & 1 & 0 & & \\
\hline $9-22$ & 1 & 1 & 0 & 0 & & & 0 & & & 1 & 1 & & 0 & & \\
\hline $9-25$ & 1 & 0 & 1 & 0 & & & 0 & & & 1 & & 1 & 0 & & \\
\hline $9-26$ & 1 & 0 & 1 & 0 & & & 0 & & & 1 & & 1 & 0 & & \\
\hline $9-27$ & 1 & 0 & 1 & 0 & & & 0 & & & 1 & & 1 & 0 & & \\
\hline $9-28$ & 1 & 0 & 1 & 0 & & & 0 & & & 1 & & 1 & 0 & & \\
\hline $9-30$ & 5 & 4 & 1 & 0 & & & 0 & & & 5 & 4 & 1 & 0 & & \\
\hline SEP & 18 & 10 & 8 & 0 & 0 & 0 & 0 & 0 & 0 & 18 & 10 & 8 & 0 & 0 & 0 \\
\hline $10-1$ & 9 & 7 & 2 & 1 & 1 & & 0 & & & 8 & 6 & 2 & 0 & & \\
\hline $10-2$ & 19 & 13 & 6 & 0 & & & 0 & & & 19 & 13 & 6 & 0 & & \\
\hline $10-3$ & 30 & 27 & 3 & 0 & & & 0 & & & 30 & 27 & 3 & 0 & & \\
\hline $10-4$ & 18 & 17 & 1 & 0 & & & 0 & & & 18 & 17 & 1 & 0 & & \\
\hline $10-5$ & 10 & 9 & 1 & 0 & & & 0 & & & 10 & 9 & 1 & 0 & & \\
\hline $10-6$ & 6 & 6 & 0 & 0 & & & 0 & & & 6 & 6 & & 0 & & \\
\hline $10-7$ & 5 & 2 & 3 & 0 & & & 0 & & & 5 & 2 & 3 & 0 & & \\
\hline $10-8$ & 15 & 10 & 5 & 0 & & & 0 & & & 15 & 10 & 5 & 0 & & \\
\hline $10-9$ & 29 & 22 & 7 & 1 & & 1 & 0 & & & 28 & 22 & 6 & 0 & & \\
\hline $10-10$ & 20 & 17 & 3 & 1 & & 1 & 0 & & & 19 & 17 & 2 & 0 & & \\
\hline $10-11$ & 25 & 23 & 2 & 0 & & & 0 & & & 25 & 23 & 2 & 0 & & \\
\hline $10-12$ & 26 & 20 & 6 & 0 & & & 0 & & & 26 & 20 & 6 & 0 & & \\
\hline $10-13$ & 19 & 14 & 5 & 1 & & 1 & 0 & & & 18 & 14 & 4 & 0 & & \\
\hline $10-14$ & 13 & 13 & 0 & 0 & & & 0 & & & 13 & 13 & & 0 & & \\
\hline $10-15$ & 26 & 26 & 0 & 0 & & & 0 & & & 26 & 26 & & 0 & & \\
\hline $10-16$ & 17 & 15 & 2 & 0 & & & 0 & & & 17 & 15 & 2 & 0 & & \\
\hline $10-17$ & 20 & 19 & 1 & 0 & & & 0 & & & 20 & 19 & 1 & 0 & & \\
\hline $10-18$ & 40 & 36 & 4 & 1 & 1 & & 0 & & & 39 & 35 & 4 & 0 & & \\
\hline $10-19$ & 73 & 71 & 2 & 2 & 2 & & 0 & & & 71 & 69 & 2 & 0 & & \\
\hline $10-20$ & 305 & 301 & 4 & 11 & 11 & & 0 & & & 294 & 290 & 4 & 0 & & \\
\hline $10-21$ & 427 & 416 & 11 & 9 & 9 & & 0 & & & 418 & 407 & 11 & 0 & & \\
\hline $10-22$ & 73 & 66 & 7 & 4 & 4 & & 0 & & & 69 & 62 & 7 & 0 & & \\
\hline $10-23$ & 57 & 55 & 2 & 2 & 2 & & 0 & & & 55 & 53 & 2 & 0 & & \\
\hline $10-24$ & 71 & 68 & 3 & 3 & 3 & & 0 & & & 68 & 65 & 3 & 0 & & \\
\hline $10-25$ & 191 & 187 & 4 & 6 & 6 & & 0 & & & 185 & 181 & 4 & 0 & & \\
\hline $10-26$ & 393 & 381 & 12 & 15 & 12 & 3 & 0 & & & 378 & 369 & 9 & 0 & & \\
\hline $10-27$ & 126 & 123 & 3 & 1 & 1 & & 0 & & & 125 & 122 & 3 & 0 & & \\
\hline $10-28$ & 32 & 30 & 2 & 2 & 2 & & 0 & & & 30 & 28 & 2 & 0 & & \\
\hline $10-29$ & 13 & 12 & 1 & 2 & 2 & & 0 & & & 11 & 10 & 1 & 0 & & \\
\hline $10-30$ & 8 & 7 & 1 & 1 & 1 & & 0 & & & 7 & 6 & 1 & 0 & & \\
\hline $10-31$ & 33 & 33 & 0 & 0 & & & 0 & & & 33 & 33 & & 0 & & \\
\hline OCT & 2149 & 2046 & 103 & 63 & 57 & 6 & 0 & 0 & 0 & 2086 & 1989 & 97 & 0 & 0 & 0 \\
\hline CUM/OCT & 2167 & 2056 & 111 & 63 & 57 & 6 & 0 & 0 & 0 & 2104 & 1999 & 105 & 0 & 0 & 0 \\
\hline $11-01$ & 30 & 30 & 0 & 1 & 1 & & 0 & & & 29 & 29 & & 0 & & \\
\hline $11-02$ & 66 & 66 & 0 & 3 & 3 & & 0 & & & 63 & 63 & & 0 & & \\
\hline $11-03$ & 39 & 39 & 0 & 2 & 2 & & 0 & & & 37 & 37 & & 0 & & \\
\hline $11-04$ & 46 & 46 & 0 & 3 & 3 & & 0 & & & 43 & 43 & & 0 & & \\
\hline $11-05$ & 60 & 59 & 1 & 2 & 2 & & 0 & & & 58 & 57 & 1 & 0 & & \\
\hline $11-06$ & 261 & 259 & 2 & 7 & 7 & & 0 & & & 254 & 252 & 2 & 0 & & \\
\hline $11-07$ & 317 & 317 & 0 & 5 & 5 & & 0 & & & 312 & 312 & & 0 & & \\
\hline $11-08$ & 128 & 125 & 3 & 6 & 6 & & 0 & & & 122 & 119 & 3 & 0 & & \\
\hline $11-09$ & 118 & 117 & 1 & 5 & 5 & & 0 & & & 113 & 112 & 1 & 0 & & \\
\hline $11-10$ & 78 & 74 & 4 & 5 & 5 & & 0 & & & 73 & 69 & 4 & 0 & & \\
\hline $11-11$ & 193 & 186 & 7 & 6 & 6 & & 0 & & & 187 & 180 & 7 & 0 & & \\
\hline $11-12$ & 215 & 213 & 2 & 0 & & & 0 & & & 215 & 213 & 2 & 0 & & \\
\hline $11-13$ & 112 & 110 & 2 & 0 & & & 0 & & & 112 & 110 & 2 & 0 & & \\
\hline $11-14$ & 279 & 276 & 3 & 0 & & & 0 & & & 279 & 276 & 3 & 0 & & \\
\hline $11-15$ & 104 & 102 & 2 & 0 & & & 0 & & & 104 & 102 & 2 & 0 & & \\
\hline $11-16$ & 66 & 65 & 1 & 0 & & & 0 & & & 66 & 65 & 1 & 0 & & \\
\hline $11-17$ & 42 & 42 & 0 & 0 & & & 0 & & & 42 & 42 & & 0 & & \\
\hline $11-18$ & 207 & 206 & 1 & 1 & 1 & & 0 & & & 206 & 205 & 1 & 0 & & \\
\hline $11-19$ & 458 & 452 & 6 & 0 & & & 0 & & & 458 & 452 & 6 & 0 & & \\
\hline $11-20$ & 146 & 144 & 2 & 0 & & & 0 & & & 146 & 144 & 2 & 0 & & \\
\hline $11-21$ & 50 & 50 & 0 & 1 & 1 & & 0 & & & 49 & 49 & & 0 & & \\
\hline $11-22$ & 10 & 9 & 1 & 0 & & & 0 & & & 10 & 9 & 1 & 0 & & \\
\hline $11-24$ & 6 & 6 & 0 & 0 & & & 0 & & & 6 & 6 & & 0 & & \\
\hline $11-27$ & 1 & 1 & 0 & 0 & & & 0 & & & 1 & 1 & & 0 & & \\
\hline $11-30$ & 1 & 1 & 0 & 0 & & & 0 & & & 1 & 1 & & 0 & & \\
\hline NOV & 3033 & 2995 & 38 & 47 & 47 & 0 & 0 & 0 & 0 & 2986 & 2948 & 38 & 0 & 0 & 0 \\
\hline CUM/NOV & 5200 & 5051 & 149 & 110 & 104 & 6 & 0 & 0 & 0 & 5090 & 4947 & 143 & 0 & 0 & 0 \\
\hline $12-04$ & 6 & 6 & 0 & 0 & & & 0 & & & 6 & 6 & & 0 & & \\
\hline $12-06$ & 68 & 68 & 0 & 0 & & & 0 & & & 68 & 68 & & 0 & & \\
\hline $12-07$ & 16 & 15 & 1 & 0 & & & 0 & & & 16 & 15 & 1 & 0 & & \\
\hline $12-08$ & 0 & 0 & 0 & 0 & & & 0 & & & 0 & & & 0 & & \\
\hline DEC & 90 & 89 & 1 & 0 & 0 & 0 & 0 & 0 & 0 & 90 & 89 & 1 & 0 & 0 & 0 \\
\hline CUM/DEC & 5290 & 5140 & 150 & 110 & 104 & 6 & 0 & 0 & 0 & 5180 & 5036 & 144 & 0 & 0 & 0 \\
\hline
\end{tabular}




\begin{tabular}{|c|c|c|c|c|c|c|c|c|c|c|c|c|c|c|c|c|c|}
\hline \multirow[b]{2}{*}{ DATE } & \multirow[b]{2}{*}{ TOTAL } & \multicolumn{3}{|c|}{ TRAPPED } & \multicolumn{3}{|c|}{ SAC/MORT } & \multicolumn{3}{|c|}{ RELEASED UPSTREAM } & \multicolumn{4}{|c|}{ RELEASED @ DAM } & \multicolumn{3}{|c|}{ BROOD } \\
\hline & & UNK & $\mathrm{H}$ & W & TOTAL & $\mathrm{H}$ & $\mathrm{W}$ & TOTAL & $\mathrm{H}$ & $\mathrm{W}$ & TOTAL & UNK & $\mathrm{H}$ & $\mathrm{W}$ & TOTAL & $\mathrm{H}$ & $\mathrm{W}$ \\
\hline $6-07$ & 1 & 0 & 1 & 0 & 0 & & & 1 & 1 & & 0 & & & & 0 & & \\
\hline $6-12$ & 1 & 0 & 1 & 0 & 0 & & & 1 & 1 & & 0 & & & & 0 & & \\
\hline $6-25$ & 3 & 0 & 2 & 1 & 0 & & & 3 & 2 & 1 & 0 & & & & 0 & & \\
\hline $6-26$ & 1 & 0 & 1 & 0 & 0 & & & 1 & 1 & & 0 & & & & 0 & & \\
\hline $6-29$ & 1 & 0 & 1 & 0 & 0 & & & 1 & 1 & 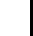 & 0 & & & & 0 & & \\
\hline JUNE & 7 & 0 & 6 & 1 & 0 & 0 & 0 & 7 & 6 & 1 & 0 & 0 & 0 & 0 & 0 & 0 & 0 \\
\hline $9-04$ & 1 & 0 & 0 & 1 & 0 & & & 0 & & & 1 & & & 1 & 0 & & \\
\hline $9-07$ & 2 & 0 & 0 & 2 & 0 & & & 0 & & & 2 & & & 2 & 0 & & \\
\hline $9-10$ & 2 & 0 & 0 & 2 & 0 & & & 0 & & & 2 & & & 2 & 0 & & \\
\hline $9-11$ & 1 & 0 & 1 & 0 & 0 & & & 0 & & & 1 & & 1 & & 0 & & \\
\hline $9-16$ & 4 & 0 & 2 & 2 & 0 & & & 0 & & & 4 & & 2 & 2 & 0 & & \\
\hline $9-17$ & 1 & 0 & 0 & 1 & 0 & & & 0 & & & 1 & & & 1 & 0 & & \\
\hline $9-18$ & 2 & 0 & 2 & 0 & 0 & & & 0 & & & 2 & & 2 & & 0 & & \\
\hline $9-19$ & 3 & 0 & 3 & 0 & 0 & & & 0 & & & 3 & & 3 & & 0 & & \\
\hline $9-20$ & 1 & 0 & 0 & 1 & 0 & & & 0 & & & 1 & & & 1 & 0 & & \\
\hline $9-21$ & 3 & 0 & 0 & 3 & 0 & & & 0 & & & 3 & & & 3 & 0 & & \\
\hline $9-23$ & 1 & 0 & 1 & 0 & 0 & & & 0 & & & 1 & & 1 & & 0 & & \\
\hline $9-24$ & 7 & 0 & 3 & 4 & 0 & & & 0 & & & 4 & & 3 & 1 & 3 & & 3 \\
\hline $9-26$ & 1 & 0 & 1 & 0 & 0 & & & 0 & & & 0 & & & & 1 & 1 & \\
\hline $9-27$ & 2 & 0 & 0 & 2 & 0 & & & 0 & & & 2 & & & 2 & 0 & & \\
\hline $9-30$ & 11 & 0 & 5 & 6 & 0 & & & 0 & & & 10 & & 5 & 5 & 1 & & 1 \\
\hline SEP & 42 & 0 & 18 & 24 & 0 & 0 & 0 & 0 & 0 & 0 & 37 & 0 & 17 & 20 & 5 & 1 & 4 \\
\hline CUM/SEP & 49 & 0 & 24 & 25 & 0 & 0 & 0 & 7 & 6 & 1 & 37 & 0 & 17 & 20 & 5 & 1 & 4 \\
\hline $10-1$ & 2 & 0 & 1 & 1 & 0 & & & 0 & & & 0 & & & & 2 & 1 & 1 \\
\hline $10-2$ & 7 & 0 & 1 & 6 & 1 & 1 & & 0 & & & 3 & & & 3 & 3 & & 3 \\
\hline $10-3$ & 8 & 0 & 4 & 4 & 0 & & & 0 & & & 8 & & 4 & 4 & 0 & & \\
\hline $10-4$ & 18 & 0 & 3 & 15 & 1 & 1 & & 0 & & & 17 & & 2 & 15 & 0 & & \\
\hline $10-5$ & 8 & 0 & 2 & 6 & 1 & 1 & & 0 & & & 7 & & 1 & 6 & 0 & & \\
\hline $10-6$ & 6 & 0 & 1 & 5 & 0 & & & 0 & & & 6 & & 1 & 5 & 0 & & \\
\hline $10-7$ & 4 & 0 & 0 & 4 & 0 & & & 0 & & & 4 & & & 4 & 0 & & \\
\hline $10-8$ & 7 & 0 & 1 & 6 & 1 & 1 & & 0 & & & 6 & & & 6 & 0 & & \\
\hline $10-9$ & 7 & 0 & 3 & 4 & 2 & 2 & & 0 & & & 5 & & 1 & 4 & 0 & & \\
\hline $10-10$ & 5 & 0 & 2 & 3 & 0 & & & 0 & & & 5 & & 2 & 3 & 0 & & \\
\hline $10-11$ & 5 & 0 & 2 & 3 & 0 & & & 0 & & & 5 & & 2 & 3 & 0 & & \\
\hline $10-12$ & 3 & 0 & 1 & 2 & 1 & 1 & & 0 & & & 2 & & & 2 & 0 & & \\
\hline $10-13$ & 5 & 0 & 3 & 2 & 1 & 1 & & 0 & & & 4 & & 2 & 2 & 0 & & \\
\hline $10-14$ & 2 & 0 & 2 & 0 & 2 & 2 & & 0 & & & 0 & & & & 0 & & \\
\hline $10-15$ & 1 & 0 & 1 & 0 & 0 & & & 0 & & & 1 & & 1 & & 0 & & \\
\hline $10-17$ & 1 & 0 & 1 & 0 & 0 & & & 0 & & & 1 & & 1 & & 0 & & \\
\hline $10-20$ & 9 & 0 & 1 & 8 & 0 & & & 0 & & & 5 & & 1 & 4 & 4 & & 4 \\
\hline $10-21$ & 10 & 0 & 3 & 7 & 2 & 2 & & 0 & & & 8 & & 1 & 7 & 0 & & \\
\hline $10-22$ & 2 & 0 & 1 & 1 & 0 & & & 0 & & & 2 & & 1 & 1 & 0 & & \\
\hline $10-23$ & 2 & 0 & 2 & 0 & 0 & & & 0 & & & 1 & & 1 & & 1 & 1 & \\
\hline $10-24$ & 2 & 0 & 0 & 2 & 0 & & & 0 & & & 0 & & & & 2 & & 2 \\
\hline $10-25$ & 5 & 0 & 0 & 5 & 0 & & & 0 & & & 1 & & & 1 & 4 & & 4 \\
\hline $10-26$ & 16 & 0 & 2 & 14 & 2 & 2 & & 0 & & & 14 & & & 14 & 0 & & \\
\hline $10-27$ & 3 & 0 & 1 & 2 & 1 & 1 & & 0 & & & 2 & & & 2 & 0 & & \\
\hline $10-28$ & 2 & 0 & 1 & 1 & 0 & & & 0 & & & 2 & & 1 & 1 & 0 & & \\
\hline $10-30$ & 1 & 0 & 1 & 0 & 1 & 1 & & 0 & & & 0 & & & & 0 & & \\
\hline $10-31$ & 1 & 0 & 1 & 0 & 1 & 1 & & 0 & & & 0 & & & & 0 & & \\
\hline OCT & 142 & 0 & 41 & 101 & 17 & 17 & 0 & 0 & 0 & 0 & 109 & 0 & 22 & 87 & 16 & 2 & 14 \\
\hline OCT/CUM & 191 & 0 & 65 & 126 & 17 & 17 & 0 & 7 & 6 & 1 & 146 & 0 & 39 & 107 & 21 & 3 & 18 \\
\hline
\end{tabular}




\begin{tabular}{|c|c|c|c|c|c|c|c|c|c|c|c|c|c|c|c|c|c|}
\hline \multirow[b]{2}{*}{ DATE } & \multirow[b]{2}{*}{ TOTAL } & \multicolumn{3}{|c|}{ TRAPPED } & \multicolumn{3}{|c|}{ SAC/MORT } & \multicolumn{3}{|c|}{ RELEASED UPSTREAM } & \multicolumn{4}{|c|}{ RELEASED @ DAM } & \multicolumn{3}{|c|}{ BROOD } \\
\hline & & UNK & $\mathrm{H}$ & W & TOTAL & $\mathrm{H}$ & $\mathrm{W}$ & TOTAL & $\mathrm{H}$ & $\mathrm{W}$ & TOTAL & UNK & $\mathrm{H}$ & $\mathrm{W}$ & TOTAL & $\mathrm{H}$ & W \\
\hline $11-02$ & 1 & 0 & 0 & 1 & 0 & & & 0 & & & 1 & & & 1 & 0 & & \\
\hline $11-03$ & 2 & 0 & 1 & 1 & 0 & & & 0 & & & 2 & & 1 & 1 & 0 & & \\
\hline $11-04$ & 2 & 0 & 1 & 1 & 0 & & & 0 & & & 2 & & 1 & 1 & 0 & & \\
\hline $11-05$ & 1 & 0 & 0 & 1 & 0 & & & 0 & & & 1 & & & 1 & 0 & & \\
\hline $11-06$ & 2 & 0 & 1 & 1 & 1 & 1 & & 0 & & & 0 & & & & 1 & & 1 \\
\hline $11-07$ & 1 & 0 & 0 & 1 & 0 & & & 0 & & & 1 & & & 1 & 0 & & \\
\hline $11-09$ & 1 & 0 & 0 & 1 & 0 & & & 0 & & & 1 & & & 1 & 0 & & \\
\hline $11-10$ & 1 & 0 & 1 & 0 & 0 & & & 0 & & & 1 & & 1 & & 0 & & \\
\hline $11-11$ & 2 & 0 & 1 & 1 & 0 & & & 0 & & & 2 & & 1 & 1 & 0 & & \\
\hline $11-12$ & 5 & 0 & 0 & 5 & 0 & & & 0 & & & 5 & & & 5 & 0 & & \\
\hline $11-13$ & 1 & 0 & 0 & 1 & 0 & & & 0 & & & 0 & & & & 1 & & 1 \\
\hline $11-14$ & 3 & 0 & 2 & 1 & 0 & & & 0 & & & 2 & & 1 & 1 & 1 & 1 & \\
\hline $11-15$ & 2 & 0 & 2 & 0 & 1 & 1 & & 0 & & & 1 & & 1 & & 0 & & \\
\hline $11-16$ & 3 & 0 & 2 & 1 & 0 & & & 0 & & & 2 & & 2 & & 1 & & 1 \\
\hline $11-17$ & 7 & 0 & 4 & 3 & 0 & & & 0 & & & 7 & & 4 & 3 & 0 & & \\
\hline $11-18$ & 7 & 0 & 2 & 5 & 2 & 2 & & 0 & & & 4 & & & 4 & 1 & & 1 \\
\hline $11-19$ & 21 & 0 & 9 & 12 & 4 & 4 & & 0 & & & 17 & & 5 & 12 & 0 & & \\
\hline $11-20$ & 25 & 0 & 7 & 18 & 4 & 4 & & 0 & & & 16 & & 3 & 13 & 5 & & 5 \\
\hline $11-21$ & 8 & 0 & 3 & 5 & 1 & 1 & & 0 & & & 7 & & 2 & 5 & 0 & & \\
\hline $11-22$ & 7 & 0 & 2 & 5 & 0 & & & 0 & & & 7 & & 2 & 5 & 0 & & \\
\hline $11-24$ & 2 & 0 & 0 & 2 & 0 & & & 0 & & & 2 & & & 2 & 0 & & \\
\hline $11-27$ & 1 & 0 & 0 & 1 & 0 & & & 0 & & & 1 & & & 1 & 0 & & \\
\hline $11-30$ & 5 & 0 & 2 & 3 & 0 & & & 0 & & & 5 & & 2 & 3 & 0 & & \\
\hline NOV & 110 & 0 & 40 & 70 & 13 & 13 & 0 & 0 & 0 & 0 & 87 & 0 & 26 & 61 & 10 & 1 & 9 \\
\hline CUM/NOV & 301 & 0 & 105 & 196 & 30 & 30 & 0 & 7 & 6 & 1 & 233 & 0 & 65 & 168 & 31 & 4 & 27 \\
\hline $12-03$ & 3 & 0 & 2 & 1 & 0 & & & 0 & & & 3 & & 2 & 1 & 0 & & \\
\hline $12-04$ & 13 & 0 & 5 & 8 & 2 & 2 & & 0 & & & 6 & & 2 & 4 & 5 & 1 & 4 \\
\hline $12-06$ & 65 & 0 & 11 & 54 & 3 & 3 & & 62 & 8 & 54 & 0 & & & & 0 & & \\
\hline $12-07$ & 130 & 0 & 24 & 106 & 7 & 7 & & 123 & 17 & 106 & 0 & & & & 0 & & \\
\hline $12-08$ & 56 & 0 & 20 & 36 & 0 & & & 56 & 20 & 36 & 0 & & & & 0 & & \\
\hline $12-09$ & 14 & 0 & 6 & 8 & 0 & & & 14 & 6 & 8 & 0 & & & & 0 & & \\
\hline $12-12$ & 16 & 0 & 6 & 10 & 0 & & & 16 & 6 & 10 & 0 & & & & 0 & & \\
\hline $12-14$ & 5 & 0 & 1 & 4 & 0 & & & 5 & 1 & 4 & 0 & & & & 0 & & \\
\hline $12-17$ & 7 & 0 & 1 & 6 & 0 & & & 7 & 1 & 6 & 0 & & & & 0 & & \\
\hline $12-19$ & 20 & 0 & 3 & 17 & 0 & & & 20 & 3 & 17 & 0 & & & & 0 & & \\
\hline $12-20$ & 59 & 0 & 17 & 42 & 0 & & & 53 & 17 & 36 & 0 & & & & 6 & & 6 \\
\hline $12-21$ & 64 & 0 & 19 & 45 & 0 & & & 64 & 19 & 45 & 0 & & & & 0 & & \\
\hline $12-22$ & 7 & 0 & 1 & 6 & 0 & & & 7 & 1 & 6 & 0 & & & & 0 & & \\
\hline $12-24$ & 3 & 0 & 2 & 1 & 0 & & & 3 & 2 & 1 & 0 & & & & 0 & & \\
\hline $12-26$ & 22 & 0 & 11 & 11 & 0 & & & 22 & 11 & 11 & 0 & & & & 0 & & \\
\hline $12-30$ & 10 & 0 & 2 & 8 & 0 & & & 10 & 2 & 8 & 0 & & & & 0 & & \\
\hline $12-31$ & 10 & 0 & 4 & 6 & 0 & & & 10 & 4 & 6 & 0 & & & & 0 & & \\
\hline $\mathrm{DEC}$ & 504 & 0 & 135 & 369 & 12 & 12 & 0 & 472 & 118 & 354 & 9 & 0 & 4 & 5 & 11 & 1 & 10 \\
\hline CUM/DEC & 805 & 0 & 240 & 565 & 42 & 42 & 0 & 479 & 124 & 355 & 242 & 0 & 69 & 173 & 42 & 5 & 37 \\
\hline $1-02$ & 3 & 0 & 1 & 2 & 0 & & & 3 & 1 & 2 & 0 & & & & 0 & & \\
\hline $1-06$ & 32 & 0 & 10 & 22 & 0 & & & 32 & 10 & 22 & 0 & & & & 0 & & \\
\hline $1-07$ & 15 & 0 & 5 & 10 & 0 & & & 15 & 5 & 10 & 0 & & & & 0 & & \\
\hline $1-09$ & 14 & 0 & 4 & 10 & 0 & & & 14 & 4 & 10 & 0 & & & & 0 & & \\
\hline $1-12$ & 16 & 0 & 5 & 11 & 0 & & & 16 & 5 & 11 & 0 & & & & 0 & & \\
\hline $1-14$ & 10 & 0 & 4 & 6 & 0 & & & 10 & 4 & 6 & 0 & & & & 0 & & \\
\hline $1-16$ & 3 & 0 & 0 & 3 & 0 & & & 0 & & & 0 & & & & 3 & & 3 \\
\hline $1-22$ & 2 & 0 & 0 & 2 & 0 & & & 0 & & & 0 & & & & 2 & & 2 \\
\hline JAN & 95 & 0 & 29 & 66 & 0 & 0 & 0 & 90 & 29 & 61 & 0 & 0 & 0 & 0 & 5 & 0 & 5 \\
\hline CUM/JAN & 900 & 0 & 269 & 631 & 42 & 42 & 0 & 569 & 153 & 416 & 242 & 0 & 69 & 173 & 47 & 5 & 42 \\
\hline
\end{tabular}




\begin{tabular}{|c|c|c|c|c|c|c|c|c|c|c|c|c|c|c|c|c|c|}
\hline \multirow[b]{2}{*}{ DATE } & \multirow[b]{2}{*}{ TOTAL } & \multicolumn{3}{|c|}{ TRAPPED } & \multicolumn{3}{|c|}{ SAC/MORT } & \multicolumn{3}{|c|}{ RELEASED UPSTREAM } & \multicolumn{4}{|c|}{ RELEASED @ DAM } & \multicolumn{3}{|c|}{ BROOD } \\
\hline & & UNK & $\mathrm{H}$ & $\mathrm{W}$ & TOTAL & $\mathrm{H}$ & $\mathrm{W}$ & TOTAL & $\mathrm{H}$ & $\mathrm{W}$ & TOTAL & UNK & $\mathrm{H}$ & $\mathrm{W}$ & TOTAL & $\mathrm{H}$ & W \\
\hline $2-04$ & 17 & 0 & 7 & 10 & 2 & 2 & & 10 & 5 & 5 & 0 & & & & 5 & & 5 \\
\hline $2-06$ & 7 & 0 & 4 & 3 & 0 & & & 4 & 3 & 1 & 0 & & & & 3 & 1 & 2 \\
\hline $2-08$ & 15 & 0 & 4 & 11 & 1 & 1 & & 11 & 3 & 8 & 0 & & & & 3 & & 3 \\
\hline $2-10$ & 37 & 0 & 12 & 25 & 4 & 4 & & 33 & 8 & 25 & 0 & & & & 0 & & \\
\hline $2-11$ & 26 & 0 & 3 & 23 & 0 & & & 26 & 3 & 23 & 0 & & & & 0 & & \\
\hline $2-12$ & 26 & 0 & 7 & 19 & 3 & 3 & & 23 & 4 & 19 & 0 & & & & 0 & & \\
\hline $2-13$ & 31 & 0 & 4 & 27 & 2 & 2 & & 29 & 2 & 27 & 0 & & & & 0 & & \\
\hline $2-14$ & 29 & 0 & 7 & 22 & 3 & 3 & & 20 & 3 & 17 & 0 & & & & 6 & 1 & 5 \\
\hline $2-15$ & 5 & 0 & 1 & 4 & 0 & & & 5 & 1 & 4 & 0 & & & & 0 & & \\
\hline $2-16$ & 23 & 0 & 2 & 21 & 0 & & & 23 & 2 & 21 & 0 & & & & 0 & & \\
\hline $2-18$ & 75 & 0 & 25 & 50 & 4 & 4 & & 71 & 21 & 50 & 0 & & & & 0 & & \\
\hline $2-19$ & 9 & 0 & 1 & 8 & 0 & & & 9 & 1 & 8 & 0 & & & & 0 & & \\
\hline $2-21$ & 17 & 0 & 10 & 7 & 4 & 4 & & 13 & 6 & 7 & 0 & & & & 0 & & \\
\hline $2-22$ & 3 & 0 & 1 & 2 & 0 & & & 3 & 1 & 2 & 0 & & & & 0 & & \\
\hline $2-23$ & 24 & 0 & 7 & 17 & 0 & & & 24 & 7 & 17 & 0 & & & & 0 & & \\
\hline $2-24$ & 58 & 0 & 23 & 35 & 0 & & & 58 & 23 & 35 & 0 & & & & 0 & & \\
\hline $2-25$ & 12 & 0 & 3 & 9 & 0 & & & 12 & 3 & 9 & 0 & & & & 0 & & \\
\hline $2-26$ & 40 & 0 & 14 & 26 & 2 & 2 & & 29 & 12 & 17 & 0 & & & & 9 & & 9 \\
\hline $2-27$ & 23 & 0 & 11 & 12 & 2 & 1 & 1 & 21 & 10 & 11 & 0 & & & & 0 & & \\
\hline $2-28$ & 12 & 0 & 2 & 10 & 0 & & & 12 & 2 & 10 & 0 & & & & 0 & & \\
\hline $2-29$ & 10 & 0 & 2 & 8 & 0 & & & 10 & 2 & 8 & 0 & & & & 0 & & \\
\hline FEB & 499 & 0 & 150 & 349 & 27 & 26 & 1 & 446 & 122 & 324 & 0 & 0 & 0 & 0 & 26 & 2 & 24 \\
\hline CUM/FEB & 1399 & 0 & 419 & 980 & 69 & 68 & 1 & 1015 & 275 & 740 & 242 & 0 & 69 & 173 & 73 & 7 & 66 \\
\hline $3-01$ & 38 & 0 & 15 & 23 & 0 & & & 38 & 15 & 23 & 0 & & & & 0 & & \\
\hline $3-03$ & 83 & 0 & 23 & 60 & 0 & & & 83 & 23 & 60 & 0 & & & & 0 & & \\
\hline $3-04$ & 27 & 0 & 5 & 22 & 0 & & & 19 & 5 & 14 & 0 & & & & 8 & & 8 \\
\hline $3-05$ & 52 & 0 & 12 & 40 & 5 & 5 & & 44 & 6 & 38 & 0 & & & & 3 & 1 & 2 \\
\hline $3-06$ & 40 & 0 & 11 & 29 & 4 & 4 & & 0 & & & 36 & & 7 & 29 & 0 & & \\
\hline $3-07$ & 9 & 0 & 2 & 7 & 0 & & & 9 & 2 & 7 & 0 & & & & 0 & & \\
\hline $3-08$ & 30 & 0 & 6 & 24 & 0 & & & 30 & 6 & 24 & 0 & & & & 0 & & \\
\hline $3-09$ & 50 & 0 & 18 & 32 & 0 & & & 50 & 18 & 32 & 0 & & & & 0 & & \\
\hline $3-10$ & 88 & 0 & 38 & 50 & 2 & 2 & & 86 & 36 & 50 & 0 & & & & 0 & & \\
\hline $3-11$ & 38 & 0 & 10 & 28 & 0 & & & 38 & 10 & 28 & 0 & & & & 0 & & \\
\hline $3-12$ & 30 & 0 & 9 & 21 & 0 & & & 30 & 9 & 21 & 0 & & & & 0 & & \\
\hline $3-13$ & 75 & 0 & 27 & 48 & 2 & 2 & & 0 & & & 73 & & 25 & 48 & 0 & & \\
\hline $3-14$ & 45 & 0 & 11 & 34 & 0 & & & 0 & & & 45 & & 11 & 34 & 0 & & \\
\hline $3-15$ & 29 & 11 & 6 & 12 & 0 & & & 0 & & & 29 & 11 & 6 & 12 & 0 & & \\
\hline $3-16$ & 53 & 21 & 13 & 19 & 0 & & & 0 & & & 53 & 21 & 13 & 19 & 0 & & \\
\hline $3-17$ & 48 & 23 & 16 & 9 & 0 & & & 0 & & & 48 & 23 & 16 & 9 & 0 & & \\
\hline $3-18$ & 75 & 21 & 24 & 30 & 0 & & & 0 & & & 75 & 21 & 24 & 30 & 0 & & \\
\hline $3-19$ & 69 & 20 & 18 & 31 & 0 & & & 0 & & & 69 & 20 & 18 & 31 & 0 & & \\
\hline $3-20$ & 16 & 4 & 4 & 8 & 0 & & & 0 & & & 16 & 4 & 4 & 8 & 0 & & \\
\hline $3-21$ & 35 & 11 & 12 & 12 & 0 & & & 0 & & & 35 & 11 & 12 & 12 & 0 & & \\
\hline $3-22$ & 20 & 5 & 4 & 11 & 0 & & & 0 & & & 20 & 5 & 4 & 11 & 0 & & \\
\hline $3-23$ & 29 & 8 & 5 & 16 & 0 & & & 0 & & & 29 & 8 & 5 & 16 & 0 & & \\
\hline $3-24$ & 58 & 0 & 11 & 47 & 0 & & & 0 & & & 47 & & 10 & 37 & 11 & 1 & 10 \\
\hline $3-25$ & 38 & 0 & 9 & 29 & 1 & 1 & & 0 & & & 37 & & 8 & 29 & 0 & & \\
\hline $3-26$ & 31 & 0 & 11 & 20 & 0 & & & 0 & & & 31 & & 11 & 20 & 0 & & \\
\hline $3-27$ & 19 & 0 & 8 & 11 & 1 & 1 & & 0 & & & 18 & & 7 & 11 & 0 & & \\
\hline $3-28$ & 9 & 0 & 2 & 7 & 0 & & & 0 & & & 9 & & 2 & 7 & 0 & & \\
\hline $3-29$ & 6 & 0 & 2 & 4 & 0 & & & 0 & & & 6 & & 2 & 4 & 0 & & \\
\hline $3-30$ & 3 & 0 & 2 & 1 & 0 & & & 0 & & & 3 & & 2 & 1 & 0 & & \\
\hline $3-31$ & 15 & 1 & 2 & 12 & 0 & & & 0 & & & 15 & 1 & 2 & 12 & 0 & & \\
\hline MARCH & 1158 & 125 & 336 & 697 & 15 & 15 & 0 & 427 & 130 & 297 & 694 & 125 & 189 & 380 & 22 & 2 & 20 \\
\hline CUM/MAR & 2557 & 125 & 755 & 1677 & 84 & 83 & 1 & 1442 & 405 & 1037 & 936 & 125 & 258 & 553 & 95 & 9 & 86 \\
\hline
\end{tabular}


Appendix A cont. 2007-08 SUMMER STEELHEAD RETURN NUMBERS

\begin{tabular}{|c|c|c|c|c|c|c|c|c|c|c|c|c|c|c|c|c|c|}
\hline \multirow[b]{2}{*}{ DATE } & \multirow[b]{2}{*}{ TOTAL } & \multicolumn{3}{|c|}{ TRAPPED } & \multicolumn{3}{|c|}{$\mathrm{SAC} / \mathrm{MORT}$} & \multicolumn{3}{|c|}{ RELEASED UPSTREAM } & \multicolumn{4}{|c|}{ RELEASED @ DAM } & \multicolumn{3}{|c|}{ BROOD } \\
\hline & & UNK & $\mathrm{H}$ & $\mathrm{W}$ & TOTAL & $\mathrm{H}$ & $\mathrm{W}$ & TOTAL & $\mathrm{H}$ & $\mathrm{W}$ & TOTAL & UNK & $\mathrm{H}$ & $\mathrm{W}$ & TOTAL & $\mathrm{H}$ & $\mathrm{W}$ \\
\hline $4-01$ & 12 & 2 & 1 & 9 & 0 & & & 0 & & & 12 & 2 & 1 & 9 & 0 & & \\
\hline $4-02$ & 18 & 3 & 6 & 9 & 0 & & & 0 & & & 18 & 3 & 6 & 9 & 0 & & \\
\hline $4-03$ & 18 & 1 & 2 & 15 & 0 & & & 0 & & & 18 & 1 & 2 & 15 & 0 & & \\
\hline $4-04$ & 22 & 1 & 5 & 16 & 0 & & & 0 & & & 22 & 1 & 5 & 16 & 0 & & \\
\hline $4-05$ & 11 & 0 & 2 & 9 & 0 & & & 0 & & & 11 & & 2 & 9 & 0 & & \\
\hline $4-06$ & 12 & 1 & 2 & 9 & 0 & & & 0 & & & 12 & 1 & 2 & 9 & 0 & & \\
\hline $4-07$ & 32 & 0 & 3 & 29 & 0 & & & 0 & & & 25 & & 3 & 22 & 7 & & 7 \\
\hline $4-08$ & 20 & 0 & 4 & 16 & 0 & & & 0 & & & 20 & & 4 & 16 & 0 & & \\
\hline $4-09$ & 23 & 0 & 7 & 16 & 0 & & & 0 & & & 17 & & 7 & 10 & 6 & & 6 \\
\hline $4-10$ & 18 & 0 & 5 & 13 & 0 & & & 0 & & & 17 & & 4 & 13 & 1 & 1 & \\
\hline $4-11$ & 42 & 0 & 3 & 39 & 0 & & & 0 & & & 41 & & 3 & 38 & 1 & & 1 \\
\hline $4-12$ & 63 & 63 & 0 & 0 & 0 & & & 0 & & & 63 & 63 & & & 0 & & \\
\hline $4-13$ & 66 & 66 & 0 & 0 & 0 & & & 0 & & & 66 & 66 & & & 0 & & \\
\hline $4-14$ & 26 & 26 & 0 & 0 & 0 & & & 0 & & & 26 & 26 & & & 0 & & \\
\hline $4-15$ & 9 & 9 & 0 & 0 & 0 & & & 0 & & & 9 & 9 & & & 0 & & \\
\hline $4-16$ & 5 & 5 & 0 & 0 & 0 & & & 0 & & & 5 & 5 & & & 0 & & \\
\hline $4-17$ & 17 & 17 & 0 & 0 & 0 & & & 0 & & & 17 & 17 & & & 0 & & \\
\hline $4-18$ & 34 & 34 & 0 & 0 & 0 & & & 0 & & & 34 & 34 & & & 0 & & \\
\hline $4-19$ & 20 & 20 & 0 & 0 & 0 & & & 0 & & & 20 & 20 & & & 0 & & \\
\hline $4-20$ & 10 & 10 & 0 & 0 & 0 & & & 0 & & & 10 & 10 & & & 0 & & \\
\hline $4-21$ & 8 & 0 & 1 & 7 & 0 & & & 0 & & & 8 & & 1 & 7 & 0 & & \\
\hline $4-22$ & 12 & 0 & 4 & 8 & 0 & & & 0 & & & 12 & & 4 & 8 & 0 & & \\
\hline $4-23$ & 6 & 0 & 4 & 2 & 0 & & & 0 & & & 6 & & 4 & 2 & 0 & & \\
\hline $4-24$ & 2 & 0 & 0 & 2 & 0 & & & 0 & & & 2 & & & 2 & 0 & & \\
\hline $4-25$ & 11 & 0 & 5 & 6 & 0 & & & 0 & & & 11 & & 5 & 6 & 0 & & \\
\hline $4-27$ & 9 & 0 & 4 & 5 & 0 & & & 0 & & & 9 & & 4 & 5 & 0 & & \\
\hline $4-28$ & 8 & 0 & 2 & 6 & 0 & & & 0 & & & 8 & & 2 & 6 & 0 & & \\
\hline $4-29$ & 4 & 0 & 2 & 2 & 0 & & & 0 & & & 4 & & 2 & 2 & 0 & & \\
\hline $4-30$ & 2 & 0 & 0 & 2 & 0 & & & 0 & & & 2 & & & 2 & 0 & & \\
\hline APRIL & 540 & 258 & 62 & 220 & 0 & 0 & 0 & 0 & 0 & 0 & 525 & 258 & 61 & 206 & 15 & 1 & 14 \\
\hline CUM/APR & 3097 & 383 & 817 & 1897 & 84 & 83 & 1 & 1442 & 405 & 1037 & 1461 & 383 & 319 & 759 & 110 & 10 & 100 \\
\hline $5-01$ & 1 & 0 & 0 & 1 & 0 & & & 0 & & & 1 & & & 1 & 0 & & \\
\hline $5-02$ & 4 & 0 & 1 & 3 & 0 & & & 0 & & & 4 & & 1 & 3 & 0 & & \\
\hline $5-03$ & 9 & 0 & 4 & 5 & 0 & & & 0 & & & 9 & & 4 & 5 & 0 & & \\
\hline $5-04$ & 4 & 0 & 0 & 4 & 0 & & & 0 & & & 4 & & & 4 & 0 & & \\
\hline $5-05$ & 2 & 0 & 1 & 1 & 0 & & & 0 & & & 2 & & 1 & 1 & 0 & & \\
\hline $5-06$ & 1 & 0 & 0 & 1 & 0 & & & 0 & & & 1 & & & 1 & 0 & & \\
\hline $5-07$ & 1 & 0 & 0 & 1 & 0 & & & 0 & & & 1 & & & 1 & 0 & & \\
\hline $5-08$ & 1 & 0 & 0 & 1 & 0 & & & 0 & & & 1 & & & 1 & 0 & & \\
\hline $5-09$ & 2 & 0 & 0 & 2 & 0 & & & 0 & & & 2 & & & 2 & 0 & & \\
\hline $5-11$ & 4 & 0 & 3 & 1 & 0 & & & 0 & & & 4 & & 3 & 1 & 0 & & \\
\hline $5-12$ & 2 & 0 & 0 & 2 & 0 & & & 0 & & & 2 & & & 2 & 0 & & \\
\hline $5-13$ & 1 & 0 & 0 & 1 & 0 & & & 0 & & & 1 & & & 1 & 0 & & \\
\hline $5-14$ & 2 & 0 & 0 & 2 & 0 & & & 0 & & & 2 & & & 2 & 0 & & \\
\hline $5-15$ & 1 & 0 & 0 & 1 & 0 & & & 0 & & & 1 & & & 1 & 0 & & \\
\hline $5-17$ & 1 & 0 & 1 & 0 & 0 & & & 0 & & & 1 & & 1 & & 0 & & \\
\hline MAY & 36 & 0 & 10 & 26 & 0 & 0 & 0 & 0 & 0 & 0 & 36 & 0 & 10 & 26 & 0 & 0 & 0 \\
\hline CUM/MAY & 3133 & 383 & 827 & 1923 & 84 & 83 & 1 & 1442 & 405 & 1037 & 1497 & 383 & 329 & 785 & 110 & 10 & 100 \\
\hline
\end{tabular}


Appendix A cont. 2008 CHS RETURN NUMBERS

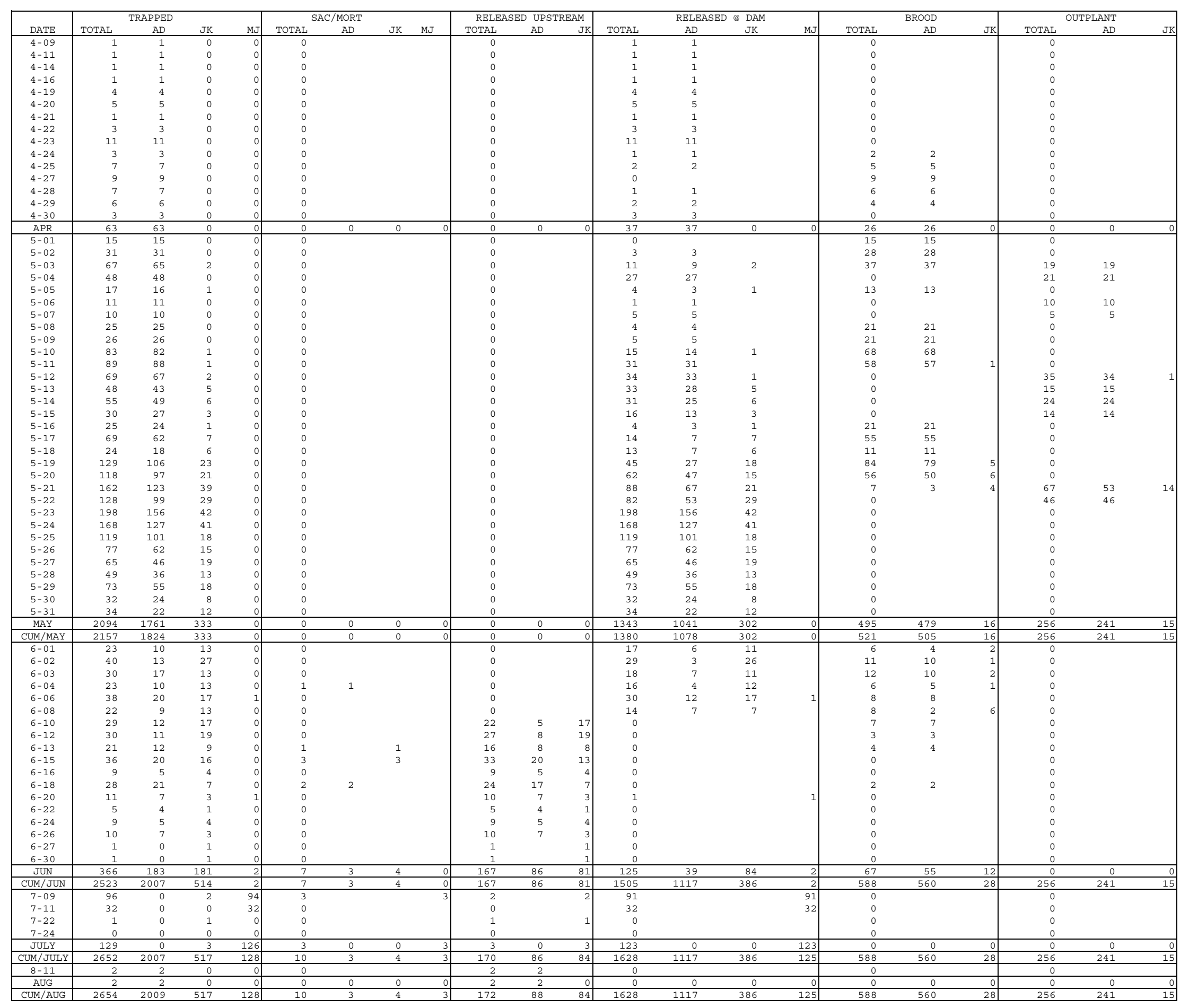


Appendix B. 2007 - 2008 Adult Transportation Summary

\begin{tabular}{|c|c|c|c|c|c|c|c|}
\hline & LOADING & LOADING & RELEASE & RELEASE & NUMBER & & LIBERATION \\
\hline DATE & SITE & TEMP & SITE & TEMP & HAULED & MORTS & UNIT \\
\hline $9 / 24 / 07$ & $3 M D$ & 62 & MINTHORN & 55 & 3 & 0 & CTUIRTRAILER \\
\hline $9 / 26 / 07$ & $3 M D$ & 60 & MINTHORN & 55 & 1 & 0 & CTUIRTRAILER \\
\hline 9/30/07 & $3 \mathrm{MD}$ & 59 & MINTHORN & 56 & 1 & 0 & CTUIRTRAILER \\
\hline $10 / 01 / 07$ & $3 \mathrm{MD}$ & 58 & MINTHORN & 57 & 2 & 0 & CTUIRTRAILER \\
\hline $10 / 02 / 07$ & $3 M D$ & 59 & MINTHORN & 57 & 3 & 0 & CTUIRTRAILER \\
\hline $10 / 20 / 07$ & $3 M D$ & 58 & MINTHORN & 54 & 4 & 0 & CTUIRTRAILER \\
\hline $10 / 23 / 07$ & $3 M D$ & 58 & MINTHORN & 54 & 1 & 0 & CTUIRTRAILER \\
\hline $10 / 24 / 07$ & $3 M D$ & 54 & MINTHORN & 55 & 2 & 0 & CTUIRTRAILER \\
\hline $10 / 25 / 07$ & $3 \mathrm{MD}$ & 55 & MINTHORN & 54 & 4 & 0 & CTUIRTRAILER \\
\hline $11 / 06 / 07$ & $3 M D$ & 47 & MINTHORN & 53 & 1 & 0 & CTUIRTRAILER \\
\hline $11 / 13 / 07$ & $3 M D$ & 46 & MINTHORN & 51 & 1 & 0 & CTUIRTRAILER \\
\hline $11 / 14 / 07$ & $3 \mathrm{MD}$ & 46 & MINTHORN & 50 & 1 & 0 & CTUIRTRAILER \\
\hline $11 / 16 / 07$ & $3 M D$ & 45 & MINTHORN & 51 & 1 & 0 & CTUIRTRAILER \\
\hline $11 / 18 / 07$ & $3 M D$ & 50 & MINTHORN & 52 & 1 & 0 & CTUIRTRAILER \\
\hline $11 / 20 / 07$ & $3 \mathrm{MD}$ & 46 & MINTHORN & 51 & 5 & 0 & CTUIRTRAILER \\
\hline $12 / 04 / 07$ & $3 \mathrm{MD}$ & 48 & MINTHORN & 52 & 5 & 0 & CTUIRTRAILER \\
\hline $12 / 06 / 07$ & $3 M D$ & 45 & BARNHART & 39 & 31 & 0 & CTUIRTRAILER \\
\hline $12 / 06 / 07$ & $3 M D$ & 45 & BARNHART & 39 & 31 & 0 & CTUIRTRAILER \\
\hline $12 / 07 / 07$ & $3 M D$ & 45 & BARNHART & 39 & 123 & 0 & CTUIRTANKER \\
\hline $12 / 08 / 07$ & $3 M D$ & 43 & BARNHART & 38 & 56 & 0 & CTUIRTRAILER \\
\hline $12 / 09 / 07$ & $3 M D$ & 39 & BARNHART & 36 & 14 & 0 & CTUIRTRAILER \\
\hline $12 / 12 / 07$ & $3 M D$ & 38 & BARNHART & 36 & 16 & 0 & CTUIRTRAILER \\
\hline $12 / 14 / 07$ & $3 M D$ & 40 & BARNHART & 37 & 5 & 0 & CTUIRTRAILER \\
\hline $12 / 17 / 07$ & $3 M D$ & 42 & BARNHART & 38 & 7 & 0 & CTUIRTRAILER \\
\hline $12 / 19 / 07$ & $3 M D$ & 42 & BARNHART & 43 & 20 & 0 & CTUIRTRAILER \\
\hline $12 / 20 / 07$ & $3 M D$ & 44 & BELOW FEED LADDER & 45 & 13 & 0 & ODFWTRAILER \\
\hline $12 / 20 / 07$ & $3 M D$ & 44 & BARNHART & 44 & 40 & 0 & CTUIRTANKER \\
\hline $12 / 20 / 07$ & $3 M D$ & 44 & MINTHORN & 42 & 6 & 0 & CTUIRTRAILER \\
\hline $12 / 21 / 07$ & $3 M D$ & 41 & BARNHART & 40 & 64 & 0 & CTUIRTRAILER \\
\hline $12 / 22 / 07$ & $3 M D$ & 41 & BARNHART & 38 & 7 & 0 & CTUIRTRAILER \\
\hline $12 / 24 / 07$ & $3 M D$ & 40 & BARNHART & 42 & 3 & 0 & CTUIRTRAILER \\
\hline $12 / 26 / 07$ & $3 M D$ & 38 & BARNHART & 35 & 22 & 0 & CTUIRTRAILER \\
\hline $12 / 30 / 07$ & $3 M D$ & 41 & BARNHART & 39 & 10 & 0 & CTUIRTRAILER \\
\hline $12 / 31 / 07$ & $3 \mathrm{MD}$ & 39 & BARNHART & 37 & 10 & 0 & CTUIRTRAILER \\
\hline $1 / 02 / 08$ & $3 M D$ & 36 & BARNHART & 35 & 3 & 0 & CTUIRTRAILER \\
\hline $1 / 06 / 08$ & $3 M D$ & 41 & BARNHART & 40 & 32 & 0 & CTUIRTRAILER \\
\hline $1 / 07 / 08$ & $3 M D$ & 40 & BARNHART & 40 & 15 & 0 & CTUIRTRAILER \\
\hline $1 / 09 / 08$ & $3 M D$ & 40 & BARNHART & 42 & 10 & 0 & CTUIRTRAILER \\
\hline $1 / 09 / 08$ & $3 M D$ & 43 & BELOW FEED LADDER & 42 & 4 & 0 & ODFWTRAILER \\
\hline $1 / 12 / 08$ & $3 M D$ & 43 & BARNHART & 41 & 16 & 0 & CTUIRTRAILER \\
\hline $1 / 14 / 08$ & $3 M D$ & 41 & BARNHART & 39 & 10 & 0 & CTUIRTRAILER \\
\hline $1 / 16 / 08$ & $3 \mathrm{MD}$ & 37 & MINTHORN & 39 & 3 & 0 & CTUIRTRAILER \\
\hline $1 / 22 / 08$ & $3 \mathrm{MD}$ & 23 & MINTHORN & 38 & 2 & 0 & CTUIRTRAILER \\
\hline
\end{tabular}




\begin{tabular}{|c|c|c|c|c|c|c|c|}
\hline & LOADING & LOADING & RELEASE & RELEASE & NUMBER & & LIBERATION \\
\hline DATE & SITE & TEMP & SITE & TEMP & HAULED & MORTS & UNIT \\
\hline $2 / 04 / 08$ & $3 \mathrm{MD}$ & 39 & BARNHART & 38 & 10 & 0 & ODFWTRAILER \\
\hline 2/04/08 & $3 M D$ & 39 & MINTHORN & 40 & 5 & 0 & CTUIRTRAILER \\
\hline 2/06/08 & $3 M D$ & 39 & BARNHART & 38 & 4 & 0 & ODFWTRAILER \\
\hline 2/06/08 & $3 M D$ & 39 & MINTHORN & 40 & 3 & 0 & CTUIRTRAILER \\
\hline 2/08/08 & $3 M D$ & 42 & BARNHART & 40 & 11 & 0 & ODFWTRAILER \\
\hline 2/08/08 & $3 \mathrm{MD}$ & 42 & MINTHORN & 42 & 3 & 0 & CTUIRTRAILER \\
\hline 2/10/08 & $3 M D$ & 44 & BARNHART & 42 & 33 & 0 & CTUIRTRAILER \\
\hline 2/11/08 & $3 M D$ & 45 & BELOW FEED LADDER & 42 & 3 & 0 & ODFWTRAILER \\
\hline 2/11/08 & $3 M D$ & 45 & BARNHART & 42 & 23 & 0 & CTUIRTRAILER \\
\hline 2/12/08 & $3 M D$ & 44 & BARNHART & 40 & 23 & 0 & CTUIRTRAILER \\
\hline 2/13/08 & $3 M D$ & 44 & BARNHART & 40 & 29 & 0 & CTUIRTRAILER \\
\hline 2/14/08 & $3 M D$ & 41 & MINTHORN & 38 & 6 & 0 & CTUIRTRAILER \\
\hline 2/14/08 & $3 M D$ & 41 & BARNHART & 40 & 20 & 0 & CTUIRTANKER \\
\hline 2/15/08 & $3 M D$ & 40 & BARNHART & 38 & 5 & 0 & ODFWTRAILER \\
\hline 2/16/08 & $3 M D$ & 40 & BARNHART & 38 & 23 & 0 & CTUIRTRAILER \\
\hline 2/18/08 & $3 M D$ & 42 & BARNHART & 40 & 71 & 0 & CTUIRTANKER \\
\hline 2/19/08 & $3 \mathrm{MD}$ & 40 & BARNHART & 39 & 9 & 0 & CTUIRTRAILER \\
\hline 2/21/08 & $3 M D$ & 42 & BARNHART & 41 & 13 & 0 & CTUIRTRAILER \\
\hline $2 / 22 / 08$ & $3 M D$ & 43 & BARNHART & 43 & 3 & 0 & CTUIRTRAILER \\
\hline $2 / 23 / 08$ & $3 M D$ & 43 & BARNHART & 44 & 24 & 0 & CTUIRTRAILER \\
\hline $2 / 24 / 08$ & $3 M D$ & 46 & BARNHART & 43 & 58 & 0 & CTUIRTRAILER \\
\hline 2/25/08 & $3 M D$ & 46 & ABOVE STANFIELD LADDER & 42 & 12 & 0 & CTUIRTRAILER \\
\hline $2 / 26 / 08$ & $3 M D$ & 45 & ABOVE STANFIELD LADDER & 42 & 29 & 0 & ODFWTRAILER \\
\hline 2/26/08 & $3 M D$ & 45 & MINTHORN & 43 & 9 & 0 & CTUIRTRAILER \\
\hline $2 / 27 / 08$ & $3 M D$ & 45 & ABOVE STANFIELD LADDER & 42 & 21 & 0 & CTUIRTRAILER \\
\hline 2/28/08 & $3 \mathrm{MD}$ & 45 & ABOVE STANFIELD LADDER & 42 & 10 & 0 & CTUIRTRAILER \\
\hline 2/28/08 & $3 M D$ & 45 & BELOW FEED LADDER & 46 & 2 & 0 & ODFWTRAILER \\
\hline $2 / 29 / 08$ & $3 \mathrm{MD}$ & 46 & ABOVE STANFIELD LADDER & 45 & 10 & 0 & CTUIRTRAILER \\
\hline 3/01/08 & $3 \mathrm{MD}$ & 47 & ABOVE STANFIELD LADDER & 44 & 38 & 0 & CTUIRTRAILER \\
\hline 3/03/08 & $3 M D$ & 42 & BARNHART & 41 & 83 & 0 & CTUIRTANKER \\
\hline 3/04/08 & $3 M D$ & 43 & STANFIELD LADDER & 43 & 19 & 0 & ODFWTRAILER \\
\hline 3/04/08 & $3 M D$ & 43 & MINTHORN & 44 & 8 & 0 & CTUIRTRAILER \\
\hline 3/05/08 & $3 M D$ & 42 & ABOVE STANFIELD LADDER & 43 & 44 & 0 & ODFWTRAILER \\
\hline 3/05/08 & $3 M D$ & 42 & MINTHORN & 40 & 3 & 0 & CTUIRTRAILER \\
\hline 3/07/08 & $3 M D$ & 43 & ABOVE STANFIELD LADDER & 42 & 9 & 0 & CTUIRTRAILER \\
\hline 3/08/09 & $3 M D$ & 46 & ABOVE STANFIELD LADDER & 43 & 30 & 0 & CTUIRTRAILER \\
\hline 3/09/08 & $3 M D$ & 47 & ABOVE STANFIELD LADDER & 45 & 50 & 0 & CTUIRTRAILER \\
\hline 3/10/08 & $3 M D$ & 46 & ABOVE STANFIELD LADDER & 43 & 86 & 0 & ODFWTRAILER \\
\hline 3/11/08 & $3 M D$ & 48 & BARNHART & 44 & 38 & 0 & ODFWTANKER \\
\hline $3 / 12 / 08$ & $3 M D$ & 49 & ABOVE STANFIELD LADDER & 44 & 30 & 0 & CTUIRTRAILER \\
\hline $3 / 24 / 08$ & $3 \mathrm{MD}$ & 46 & MINTHORN & 47 & 11 & 0 & CTUIRTRAILER \\
\hline $4 / 07 / 08$ & $3 \mathrm{MD}$ & 49 & MINTHORN & 49 & 7 & 0 & CTUIRTRAILER \\
\hline $4 / 09 / 08$ & $3 M D$ & 47 & MINTHORN & 49 & 6 & 0 & CTUIRTRAILER \\
\hline $4 / 10 / 08$ & $3 M D$ & 49 & MINTHORN & 49 & 1 & 0 & CTUIRTRAILER \\
\hline $4 / 11 / 08$ & $3 M D$ & 50 & MINTHORN & 52 & 1 & 0 & CTUIRTRAILER \\
\hline $4 / 24 / 08$ & $3 M D$ & 50 & SFWW & 49 & 2 & 0 & CTUIRTANKER \\
\hline $4 / 25 / 08$ & $3 M D$ & 49 & SFWW & 50 & 5 & 0 & ODFWTANKER \\
\hline $4 / 27 / 08$ & $3 \mathrm{MD}$ & 52 & SFWW & 46 & 9 & 0 & CTUIRTANKER \\
\hline $4 / 28 / 08$ & $3 M D$ & 53 & SFWW & 46 & 6 & 0 & CTUIRTANKER \\
\hline $4 / 29 / 08$ & $3 \mathrm{MD}$ & 53 & SFWW & 47 & 4 & 0 & CTUIRTANKER \\
\hline
\end{tabular}




\begin{tabular}{|c|c|c|c|c|c|c|c|}
\hline & LOADING & LOADING & RELEASE & RELEASE & NUMBER & & LIBERATION \\
\hline DATE & SITE & TEMP & SITE & TEMP & HAULED & MORTS & UNIT \\
\hline $5 / 01 / 08$ & $3 M D$ & 47 & SFWW & 46 & 15 & 0 & CTUIRTANKER \\
\hline $5 / 02 / 08$ & $3 M D$ & 50 & SFWW & 45 & 28 & 0 & ODFWTANKER \\
\hline $5 / 03 / 08$ & $3 M D$ & 53 & SFWW & 45 & 56 & 0 & ODFWTANKER \\
\hline $5 / 04 / 08$ & $3 \mathrm{MD}$ & 51 & SFWW & 45 & 21 & 0 & CTUIRTANKER \\
\hline $5 / 05 / 08$ & $3 M D$ & 52 & SFWW & 46 & 13 & 0 & CTUIRTANKER \\
\hline $5 / 06 / 08$ & $3 \mathrm{MD}$ & 53 & SFWW & 45 & 10 & 0 & CTUIRTANKER \\
\hline $5 / 07 / 08$ & $3 M D$ & 51 & SFWW & 45 & 5 & 0 & CTUIRTANKER \\
\hline $5 / 08 / 08$ & $3 M D$ & 49 & SFWW & 44 & 21 & 0 & CTUIRTANKER \\
\hline $5 / 09 / 08$ & $3 M D$ & 49 & SFWW & 42 & 21 & 0 & ODFWTANKER \\
\hline $5 / 10 / 08$ & $3 M D$ & 50 & SFWW & 42 & 68 & 0 & ODFWTANKER \\
\hline $5 / 11 / 08$ & $3 M D$ & 49 & SFWW & 46 & 58 & 0 & ODFWTANKER \\
\hline $5 / 12 / 08$ & $3 M D$ & 50 & SFWW & 44 & 35 & 0 & CTUIRTANKER \\
\hline $5 / 13 / 08$ & $3 \mathrm{MD}$ & 52 & SFWW & 45 & 15 & 0 & ODFWTANKER \\
\hline $5 / 14 / 08$ & $3 \mathrm{MD}$ & 52 & SFWW & 45 & 24 & 0 & ODFWTANKER \\
\hline $5 / 15 / 08$ & $3 M D$ & 55 & SFWW & 45 & 14 & 0 & CTUIRTANKER \\
\hline $5 / 16 / 08$ & $3 M D$ & 55 & SFWW & 44 & 21 & 0 & CTUIRTANKER \\
\hline $5 / 17 / 08$ & $3 M D$ & 55 & SFWW & 42 & 55 & 0 & ODFWTANKER \\
\hline $5 / 18 / 08$ & $3 \mathrm{MD}$ & 57 & SFWW & 44 & 11 & 0 & CTUIRTANKER \\
\hline $5 / 19 / 08$ & $3 M D$ & 56 & SFWW & 46 & 84 & 0 & CTUIRTANKER \\
\hline $5 / 20 / 08$ & $3 \mathrm{MD}$ & 56 & SFWW & 44 & 56 & 0 & CTUIRTANKER \\
\hline $5 / 21 / 08$ & 3MD & 50 & SFWW & 40 & 74 & 0 & ODFWTANKER \\
\hline $5 / 21 / 08$ & RINGOLD & 62 & SFWW & 44 & 109 & 0 & CTUIRTANKER \\
\hline $5 / 22 / 08$ & 3MD & 50 & SFWW & 43 & 46 & 0 & CTUIRTANKER \\
\hline $5 / 29 / 08$ & RINGOLD & 62 & SFWW & 44 & 55 & 0 & CTUIRTANKER \\
\hline 6/01/08 & 3MD & 58 & SFWW & 45 & 6 & 0 & ODFWTANKER \\
\hline 6/02/08 & $3 M D$ & 56 & SFWW & 44 & 11 & 0 & CTUIRTANKER \\
\hline 6/03/08 & $3 M D$ & 57 & SFWW & 43 & 12 & 0 & ODFWTANKER \\
\hline 6/04/08 & 3MD & 54 & SFWW & 45 & 6 & 0 & ODFWTANKER \\
\hline 6/04/08 & RINGOLD & 62 & SFWW & 46 & 25 & 0 & CTUIRTANKER \\
\hline 6/06/08 & 3MD & 54 & SFWW & 46 & 8 & 0 & CTUIRTANKER \\
\hline 6/08/08 & $3 M D$ & 56 & SFWW & 45 & 8 & 0 & CTUIRTANKER \\
\hline 6/10/08 & $3 \mathrm{MD}$ & 58 & SFWW & 44 & 7 & 0 & CTUIRTANKER \\
\hline 6/10/08 & $3 \mathrm{MD}$ & 58 & BARNHART & 56 & 22 & 0 & ODFWTANKER \\
\hline 6/12/08 & $3 \mathrm{MD}$ & 54 & SFWW & 49 & 3 & 0 & ODFWTANKER \\
\hline $6 / 12 / 08$ & $3 \mathrm{MD}$ & 54 & BARNHART & 52 & 27 & 0 & ODFWTANKER \\
\hline 6/13/08 & $3 \mathrm{MD}$ & 57 & BARNHART & 55 & 16 & 0 & ODFWTANKER \\
\hline 6/13/08 & $3 M D$ & 57 & SFWW & 46 & 4 & 0 & CTUIRTRAILER \\
\hline 6/15/08 & $3 M D$ & 57 & BARNHART & 51 & 33 & 0 & CTUIRTANKER \\
\hline 6/16/08 & $3 \mathrm{MD}$ & 59 & BARNHART & 54 & 9 & 0 & CTUIRTANKER \\
\hline 6/18/08 & $3 \mathrm{MD}$ & 60 & BARNHART & 54 & 24 & 0 & CTUIRTANKER \\
\hline 6/18/08 & $3 M D$ & 60 & SFWW & 48 & 2 & 0 & CTUIRTRAILER \\
\hline $6 / 20 / 08$ & $3 \mathrm{MD}$ & 64 & BARNHART & 61 & 10 & 0 & ODFWTANKER \\
\hline $6 / 22 / 08$ & $3 \mathrm{MD}$ & 64 & BARNHART & 60 & 5 & 0 & CTUIRTRAILER \\
\hline $6 / 24 / 08$ & $3 \mathrm{MD}$ & 63 & BARNHART & 60 & 9 & 0 & CTUIRTRAILER \\
\hline 6/26/08 & $3 M D$ & 66 & BARNHART & 61 & 10 & 0 & CTUIRTRAILER \\
\hline $6 / 27 / 08$ & $3 \mathrm{MD}$ & 67 & BARNHART & 65 & 1 & 0 & ODFWTRAILER \\
\hline 6/30/08 & $3 \mathrm{MD}$ & 73 & THORNHOLLOW & 64 & 1 & 0 & CTUIRTRAILER \\
\hline $7 / 09 / 08$ & $3 \mathrm{MD}$ & 72 & BEAR CR & 63 & 2 & 0 & ODFWTRAILER \\
\hline $7 / 22 / 08$ & $3 M D$ & 70 & BEAR CR & 55 & 1 & 0 & CTUIRTRAILER \\
\hline $7 / 24 / 08$ & $3 \mathrm{MD}$ & 68 & BEAR CR & 60 & 2 & 0 & CTUIRTRAILER \\
\hline $7 / 25 / 08$ & $3 \mathrm{MD}$ & 69 & BEAR CR & 60 & 1 & 0 & CTUIRTRAILER \\
\hline 8/05/08 & $3 M D$ & 70 & BEAR CR & 61 & 1 & 0 & CTUIRTRAILER \\
\hline 8/11/08 & $3 M D$ & 68 & BEAR CR & 56 & 2 & 0 & CTUIRTRAILER \\
\hline $8 / 12 / 08$ & $3 \mathrm{MD}$ & 70 & BARNHART & 65 & 1 & 0 & CTUIRTRAILER \\
\hline
\end{tabular}


Appendix C. 2008 Juvenile Transportation Summary

\begin{tabular}{|c|cccccc|}
\hline & LOADING & LOADING & RELEASE & RELEASE & POUNDS & LIBERATION \\
DATE & SITE & TEMP & SITE & TEMP & HAULED & UNIT \\
\hline $7 / 14 / 08$ & Westland & 66 & Col.River above Umatlla Marina & 65 & 36.0 & CTUIRTRAILER \\
$7 / 15 / 08$ & Westland & 68 & Below Westland Dam & 68 & 12.0 & CTUIRTRAILER \\
$7 / 16 / 08$ & Westland & 65 & Col.River above Umatlla Marina & 65 & 11.0 & CTUIRTRAILER \\
$7 / 16 / 08$ & Westland & 65 & Below Westland Dam & 66 & 1.0 & 5 gallon bucket \\
$7 / 17 / 08$ & Westland & 66 & Umatilla Boat Ramp & 65 & 2.0 & CTUIRTRAILER \\
$7 / 18 / 08$ & Westland & 68 & Umatilla Boat Ramp & 68 & 2.0 & CTUIRTRAILER \\
\hline
\end{tabular}


Appendix D

UMATILLA HATCHERY AND BASIN ANNUAL OPERATION PLAN

FOR THE PERIOD OF

OCTOBER 1, 2007 - SEPTEMBER 30, 2008

PREPARED BY:

OREGON DEPARTMENT OF FISH AND WILDLIFE

AND THE

CONFEDERATED TRIBES OF THE UMATILLA INDIAN RESERVATION

FOR

BONNEVILLE POWER ADMINISTRATION

Final

September 1, 2007 


\section{UMATILLA HATCHERY AND BASIN ANNUAL OPERATION PLAN \\ OCTOBER 1, 2007- SEPTEMBER 30, 2008 TABLE OF CONTENTS}

I. Introduction
A. Water Supply. 3
B. Staffing 3

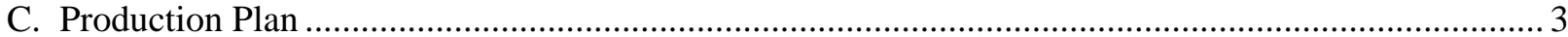

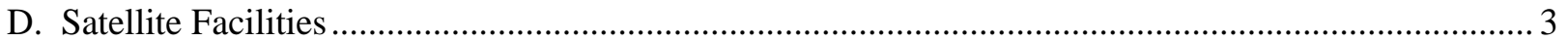
E. Fish Production October 1, 2005 to September 30, 2006.............................................................. 4

II. Facility Operations.......................................................................... 5

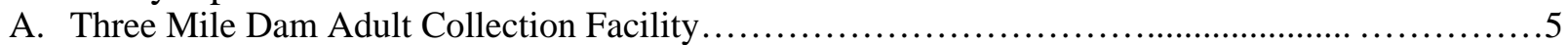

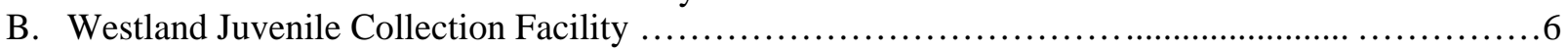

C. McKay Reservoir Releases For Fish Passage/Rearing .................................................6

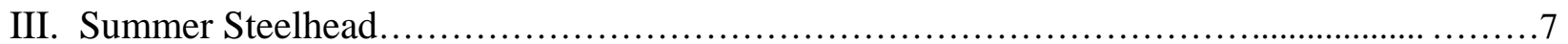

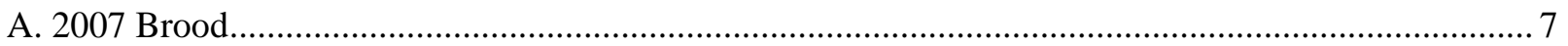

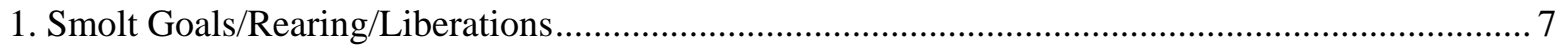

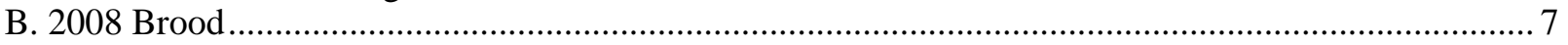

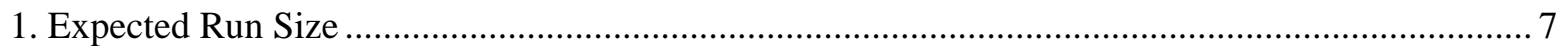

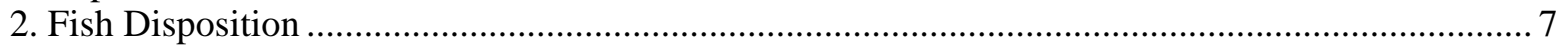

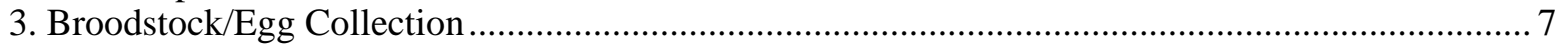

4. Smolt Goals/Rearing/Liberations ............................................................................................. 7

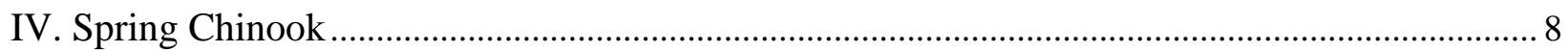

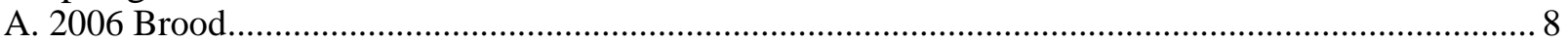

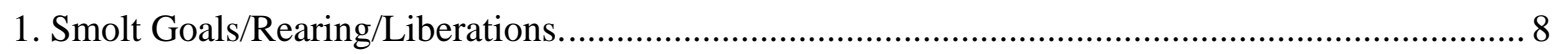

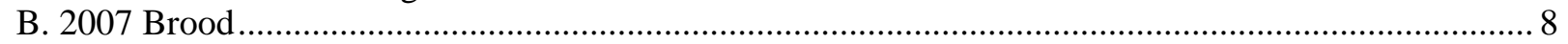

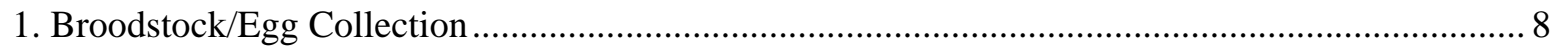

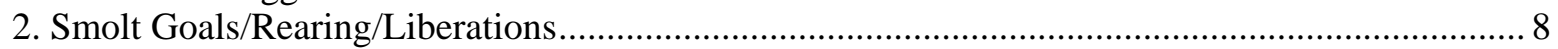

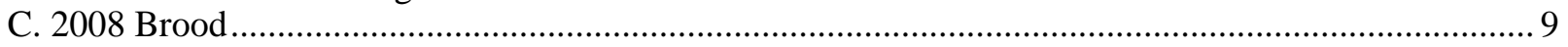

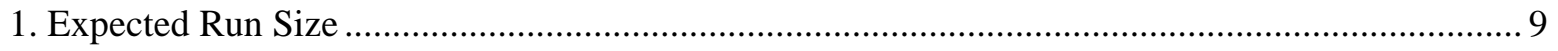

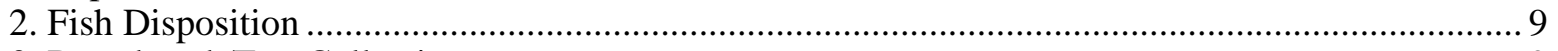

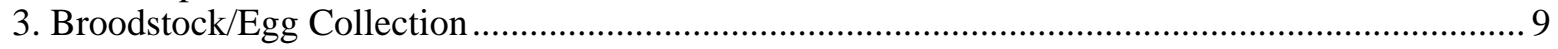

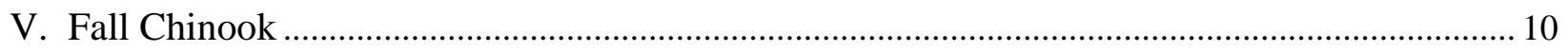

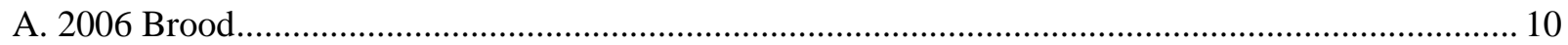

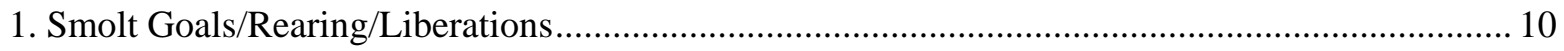

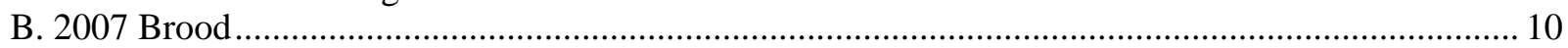

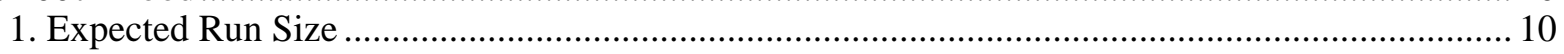

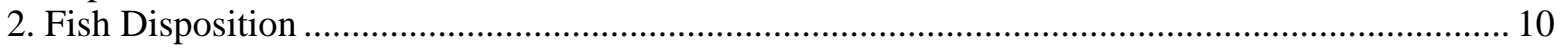

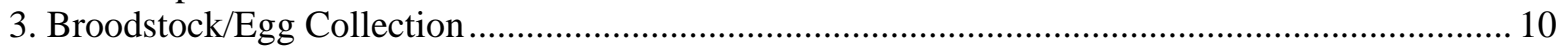

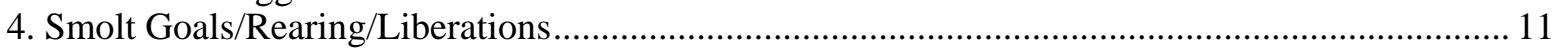

5. Idaho Power Company_Subyearling/Goals/Rearing/Liberations ............................................... 11

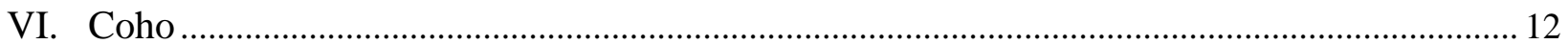

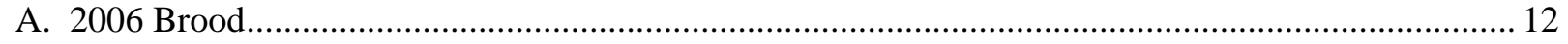

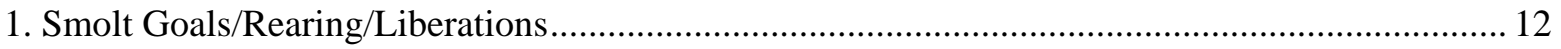

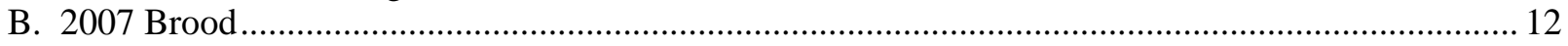

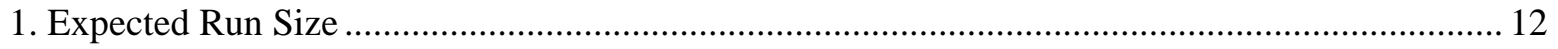

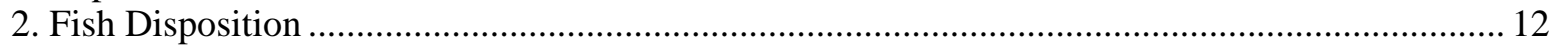

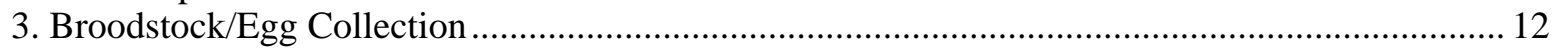




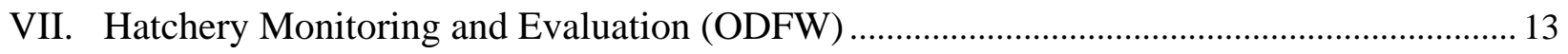

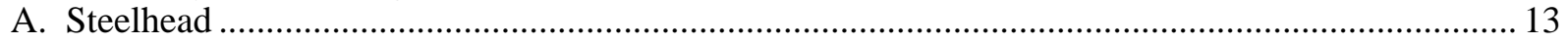

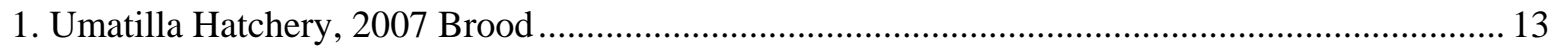

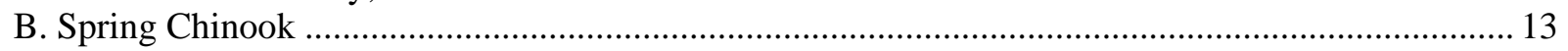

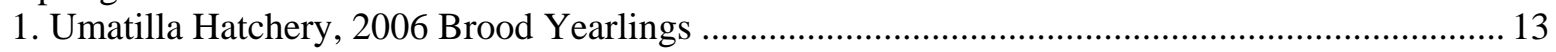

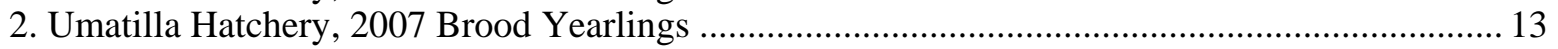

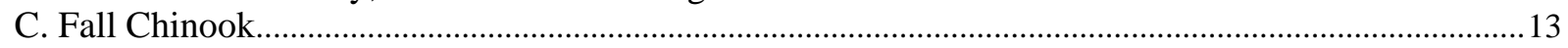

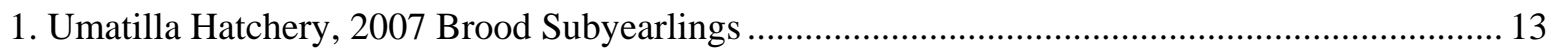

2. Bonneville Hatchery, 2006 Brood Yearlings ................................................................................ 13

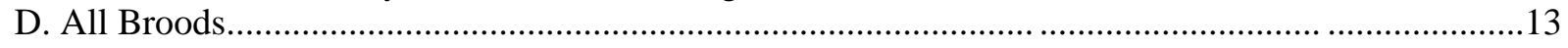

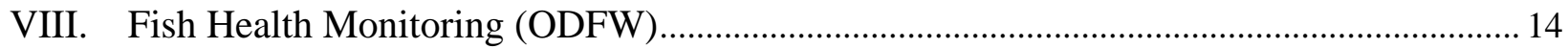

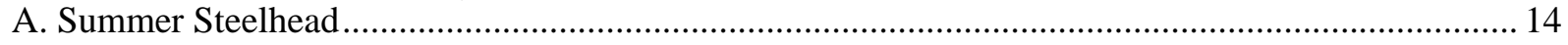

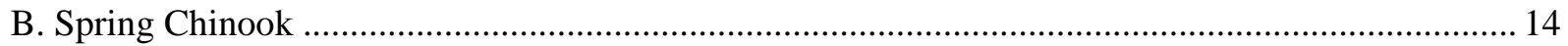

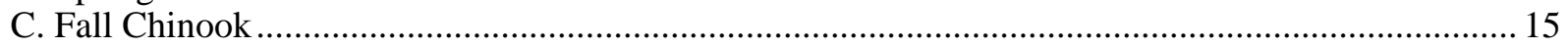

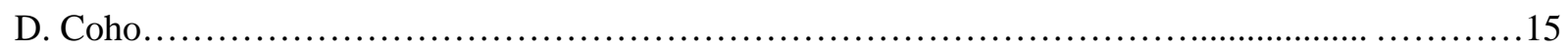

IX. Natural Production Evaluation (CTUIR)............................................................................ 16

X. Interim Umatilla Basin Spring Chinook Management Guidelines (2007-08) .......................16

XI. Bureau of Reclamation Monitoring and Evaluation Program ............................................... 18 


\section{INTRODUCTION}

Fish production was initiated at Umatilla Hatchery in 1991. Many design and construction challenges have been addressed although the quantity of well water continues to be problematic. This document focuses on fish production at Umatilla Hatchery and on other facilities involved in the Umatilla program. Other sub-basin operations such as fish passage and research activities are briefly mentioned. Monitoring and evaluation plans have been developed and are ongoing with current production plans. Chinook salmon and steelhead released in the Umatilla basin are tagged or marked according to monitoring and evaluation ( $\mathrm{M} \& \mathrm{E}$ ) requirements and for identification.

\section{A. Water Supply}

The current hatchery water supply is only 5,500 gpm although the infrastructure was designed for $15,000 \mathrm{gpm}$. Water temperatures range from $54^{\circ} \mathrm{F}$ to $58^{\circ} \mathrm{F}$. ODFW engineering staff has reviewed designs for water treatment to increase production capacity.

\section{B. Staffing}

Oregon Department of Fish and Wildlife (ODFW) Umatilla Hatchery staff consists of one F\&W Manager 1, one F\&W Technician 2, three F\&W Technician 1's, one half-time F\&W Technician 1, two Facilities Maintenance Specialists, and six months of administrative support. Six months of Liberation staff includes one 3-month position contracted with Oregon Department of Forestry, one month F\&W Tech 2, one month Equipment Operator 2, and one month F\&W Tech 3.

\section{Production Plan}

The Power Planning Council's 1987 Fish and Wildlife Program authorized construction of a hatchery to produce 7.44 million salmon and steelhead weighing 255,000 pounds for release in the Umatilla River. However, well water shortages have limited Umatilla Hatchery production. The current production proposal is 2.15 million fish weighing 115,681 pounds (Table 1). Reviewers of this plan should note that the Umatilla Hatchery is operated under the Power Planning Council's system policies of adaptive management to determine production goals.

The Umatilla Hatchery fish production is based on available water. When additional water becomes available, the production plan will be modified. Ideally, an additional 10,000gpm (15,000gpm total) of well water should be developed to meet production plans.

There are still concerns about hatchery fall Chinook adults straying into other basins. The following steps have been taken to address these concerns; 1 ) subyearling production has been reduced to 600,000 fish, 2) all juveniles are being wire tagged, 3) collection facilities are in place on the Snake River to remove up to $15 \%$ of the Umatilla stray fish, 4) Phase 1 and 2 (phase 3 is in development) of the Umatilla Basin Water Exchange Project are complete and in operation, and 5) smolts are either acclimated or released higher (mid-river) to improve imprinting to the Umatilla River.

\section{Satellite Facilities}

The Confederated Tribes of the Umatilla Indian Reservation (CTUIR) in conjunction with ODFW are currently operating four (Bonifer has not been operated since 2005) juvenile acclimation/release facilities and two adult holding and spawning facilities for spring and fall Chinook and Coho salmon, and summer steelhead.

\begin{tabular}{|c|c|c|c|c|c|c|c|}
\hline Species & Stock & Rearing & Number & Pounds & FPP & Age & Release \\
\hline
\end{tabular}




\begin{tabular}{|c|c|c|c|c|c|c|c|}
\hline & & Type & & & & & Time \\
\hline ChS & Umatilla & Michigan & 810,000 & 54,000 & 15 & $1+$ & Spring \\
\hline \multicolumn{3}{|c|}{ ChS Subtotal } & 810,000 & 54,000 & & & \\
\hline ChF & Upriver Brights & Oregon & 300,000 & 6,000 & 50 & $0+$ & Spring \\
\hline ChF & Upriver Brights & Oregon & 300,000 & 8,570 & 35 & $0+$ & Spring \\
\hline ChF & $\begin{array}{l}\text { Snake River } \\
\text { Lyons Ferry } \\
\end{array}$ & Michigan & 800,000 & 14,545 & 55 & $0+$ & Spring \\
\hline \multicolumn{3}{|c|}{ ChF Subtotal } & $1,400,000$ & 29,115 & & & \\
\hline StS & Umatilla & Michigan & 150,000 & 33,333 & 4.5 & $1+$ & Spring \\
\hline \multicolumn{3}{|c|}{ StS Subtotal } & 150,000 & 33,333 & & & \\
\hline \multicolumn{3}{|c|}{ Production Total } & $2,360,000$ & 116,448 & & & \\
\hline
\end{tabular}

E. Fish Production October 1, 2006 to September 30, 2007.

\begin{tabular}{|lccl|}
\hline HATCHERY/SPECIES & $\begin{array}{c}\text { FY 2007 } \\
\text { ACTUAL }\end{array}$ & $\begin{array}{c}\text { US v Oregon } \\
\text { goals }\end{array}$ & $\begin{array}{l}\text { FUNDING } \\
\text { SOURCE }\end{array}$ \\
\hline UMATILLA & & & \\
Fall Chinook Sub-yearlings & $616 \mathrm{~K}$ & $600 \mathrm{~K}$ & BPA \\
Fall Chinook Sub-yearlings & $0 \mathrm{~K}$ & $800 \mathrm{~K}$ & IPC \\
Fall Chinook Sub-yearlings & $0 \mathrm{~K}$ & 0 & COE \\
Spring Chinook Yearlings & $667 \mathrm{~K}$ & $600 \mathrm{~K}$ & BPA \\
Summer Steelhead & 141 & $150 \mathrm{~K}$ & BPA \\
LITTLE WHITE SALMON & & & \\
Spring Chinook Yearlings & $213 \mathrm{~K}$ & $210 \mathrm{~K}$ & BPA \\
BONNEVILLE & & & \\
Fall Chinook Yearlings & $470 \mathrm{~K}$ & $480 \mathrm{~K}$ & John Day \\
CASCADE & & & \\
Coho & $1.0 \mathrm{M}$ & $1.0 \mathrm{M}$ & Mitchell \\
CASCADE HATCHERY & & & \\
\hline Lower Herman Creek & & & \\
Coho & $493 \mathrm{~K}$ & $500 \mathrm{~K}$ & Mitchell \\
\hline
\end{tabular}

\section{FACILITY OPERATIONS}


The Three Mile Falls Dam (TMFD) fish ladder and adult collection trap will begin operations August 16 in conjunction with the fall startup of Phase I of the Umatilla Basin Water Exchange Project. The intent of Phase I is to attract fall returning adults from the Columbia River into the lower Umatilla River below TMFD. The trap is operated throughout the fall to collect broodstock and daily run data. Broodstock will be collected proportional to the most recent 5-year average run timing for both natural and hatchery steelhead and the combined hatchery and natural returns for Chinook. Information collected during trapping on all Chinook, coho, and steelhead will include date, disposition, and number trapped by sex, age class, fin marks, and tag type along with general observations of fish condition. Age classifications for Chinook based on fork length are subjack - fish less than 15.75" (400mm), jack - fish between 15.75” and 24” (400-609mm), and adult - fish equal to or larger than 24” (610mm). For coho, jacks are less than $18 "(457 \mathrm{~mm})$ and adults are equal to or larger than 18". For steelhead, onesalt fish are less than 26 ” $(660 \mathrm{~mm})$ and two-salt fish are equal to or greater than 26 ”. Fork and/or mid-eye to hypural (MEHP) lengths will be measured on a subsample of the run during spawning, creel and spawning ground surveys, and coded-wire tag recovery at the trap. A portion of the Chinook, coho, and steelhead will be sacrificed for CWT recovery during trapping to meet M\&E data needs (see "Fish Disposition" sections for specific numbers that will be collected for each species). Snout ID numbers will be used for all CWT recoveries at the trap and during all other M\&E activities to associate CWT information with their corresponding sex, length, and mark data.

The TMFD adult fish trap will be operated on a five days on and nine days off schedule beginning on approximately December 1 and continuing through mid April. The intent is to reduce handling and allow volitional migration of steelhead and spring Chinook adults through the facility, but maintain enough trapping to meet collection rates in Table 5. During the off days (non-trapping), CTUIR will use video tape to record passage and enumerate salmon and steelhead swimming past the viewing window. Data collected from video will include identification of species, number, jack and adult age classes for spring Chinook and hatchery vs. wild origin for steelhead when visibility permits. Fish viewed when conditions are not adequate to view marks will be classified as "unknown". Origin, sex, mark, and age information not identified during video monitoring will be estimated at the end of the year by the Umatilla Hatchery M\&E Project based on the mean proportions observed during trapping periods immediately prior to and after each video period.

Specific components of the run data are maintained by multiple projects. The Umatilla Hatchery M\&E Project annually reports number of adult returns to TMFD and the river mouth by hatchery-natural origin and adult age classes, run composition by sex and adult age classification, and CWT information including release history of hatchery returns and out-ofbasin recoveries of Umatilla origin hatchery fish. The Umatilla Basin Natural Production M\&E Project annually reports number of adult returns to TMFD by hatchery-natural origin and adult age classes. In addition, they also report disposition of adult returns from TMFD to natural spawning, and juvenile age structure of natural adult returns. The Umatilla Basin Passage Operations Project annually reports daily returns to TMFD by adult age class for salmon and hatchery-natural origin for steelhead as well as their disposition at TMFD. The Stream Net database (www.streamnet.org) only reports annual returns to TMFD by adults and jack age classes for salmon and hatchery and natural origin for steelhead 
Trap and haul will only be implemented in the fall and winter (August 16 - March 31) if physical passage conditions are unacceptable at Feed Canal Dam. Otherwise all fish will be released at TMFD. During the period from April 1 to early July, trap and haul will be implemented if the passage flow criteria of $150 \mathrm{cfs}$ for 30 days after release cannot be met or if physical passage conditions are unacceptable at Feed Canal Dam. Release sites will be determined based on species composition, fisheries, and river conditions. If flows at Pendleton drop below 250 cfs during this period fish will be hauled upstream and released into the upper basin above Pendleton.

\section{B. Westland Juvenile Collection Facility}

The Westland juvenile collection facility will be operated when spring/summer flows are below 150 cfs for ten days downstream of Westland Dam. As flows decline, causing concern for stranding fish, practical efforts will be made to block downstream migration and implement trap and haul. Steelhead and salmon collected will be transferred and released at the mouth of the Umatilla River. If the WEID pumps are operating during the period when fish are being hauled from Westland, juveniles will be released into the Columbia River as near to the mouth of the Umatilla as is logistically feasible. When the number and composition of the trapped fish is mostly non-migrants or resident fish, the trap will be closed and trap and haul operations discontinued.

\section{McKay Reservoir Releases For Fish Passage/Rearing}

Stored water in McKay Reservoir (designated for fish flow augmentation and made available through the Umatilla Basin Water Exchange project) will be released based on the priorities outlined in Table 3. The flow targets identified are for area from mouth of McKay Creek to mouth of Umatilla River with the expected low flow point occurring below Dillon Dam. The recommendations in Table 3 are guidelines only, the actual time periods and flow levels may change depending on availability of water.

Table 3. Prioritized time periods for the release of fish flow augmentation water from McKay Reservoir.

\begin{tabular}{|l|c|c|c|}
\hline Time Period & $\begin{array}{c}\text { Flow } \\
\text { (cfs) }\end{array}$ & $\begin{array}{c}\text { Primary Release Purpose } \\
\text { (Species/ Life History) }\end{array}$ & $\begin{array}{c}\text { Release } \\
\text { Priority }\end{array}$ \\
\hline March - July & 150 & $\begin{array}{c}\text { CHS Adults } \\
\text { CHF J Out migration } \\
\text { Lamprey Adults }\end{array}$ & 1 \\
\hline July - Sept & 50 & $\begin{array}{c}\text { Lamprey Adults } \\
\text { Coho, STS, Lamprey, JV Rearing } \\
\text { CHF JV Out migration }\end{array}$ & 3 \\
\hline Sept - Nov & 150 & Coho, CHF, STS Adults & 2 \\
\hline
\end{tabular}




\section{SUMMER STEELHEAD}

A. 2007 Brood

Smolt Goals/Rearing/Liberations -The Umatilla Hatchery summer steelhead production goal is 150,000 smolts. .

In September or October 2007, all fish will be adipose (AD) fin clipped. In November, three groups of 20,000 fish (one group per release site) will be left ventral (LV) fin clipped and coded wire tagged (CWT).

Two groups of 50,000 fish each will be transferred to Pendleton and Minthorn in early April and released in late April. The third group (50,000 fish) will be direct stream released near the Bonifer site in Boston Canyon (RM2) and released in late April. Acclimated groups will be held for approximately three weeks, released volitionally for one week, and then forced out. The target size is 4.5fpp.

\section{B. 2008 Brood}

\section{Expected Run Size $-2,824 \pm 294$}

2. Fish Disposition - A target of 55 pair adult fish will be collected for broodstock and CWT recovery (Table 4). Broodstock will consist of 50 pair wild and 5 pair hatchery (CWT) for Umatilla Hatchery production. An additional 94 CWT's may be collected by the combination of sacrificing fish at the trap and creel survey sampling in the Umatilla River to meet the M\&E requirement of 104 CWT recoveries. All ADRV adults collected at TMFD will be considered Wallowa strays and euthanized. Carcasses will be distributed by CTUIR.

3. Broodstock/Egg Collection - The broodstock goal is 55 pair.

Broodstock will be collected at Three Mile Dam from September through April (Table 5). Each fish will be anesthetized with CO2. Fish will be transferred to Minthorn for holding and spawning.

Spawning at Minthorn will start the last Wednesday in March. Individual fecundity estimates will be made (Section X). A 3x3 spawning matrix will be utilized whenever possible. Matrices will select for wild $\mathrm{x}$ wild crosses whenever possible, however, no hatchery $\mathrm{x}$ hatchery crosses will be used. Males will be used only once. Coded wire tags will be read prior to spawning. Fish determined to be out-of-basin strays will not be used for broodstock. Approximately 201,000 green eggs will be collected from 42 females (fecundity 5,289) and transferred to Umatilla Hatchery.

Note: Scales should be collected from unmarked adults used for broodstock

Table 4. Collection guidelines for summer steelhead broodstock and CWT sacrifices (5-year average).

\begin{tabular}{|c|c|c|c|c|c|c|c|c|c|}
\hline & Total & Sept. & Oct. & Nov. & Dec. & Jan. & Feb. & Mar. & Apr. \\
\hline $\begin{array}{l}\text { Broodstock - } \\
\text { Wild }\end{array}$ & $\begin{array}{c}100 \\
(50 \mathrm{pr})\end{array}$ & 5 & 13 & 9 & 10 & 15 & 14 & 20 & 14 \\
\hline \multirow{3}{*}{$\begin{array}{l}\text { Broodstock- } \\
\text { Hatchery } \\
\text { CWT } \\
\text { sampling }\end{array}$} & $\begin{array}{c}10 \\
(5 \mathrm{pr})\end{array}$ & 1 & 2 & 1 & 1 & 1 & 1 & 2 & 1 \\
\hline & 94 & 8 & 15 & 10 & 10 & 13 & 12 & 17 & 9 \\
\hline & $\begin{array}{c}104 \\
\text { CWT }\end{array}$ & & & & & & & & \\
\hline
\end{tabular}

4. Smolt Goals/Rearing/Liberations - The Umatilla Hatchery summer steelhead production goal is 150,000 smolts.

Approximately 164,000-eyed eggs will produce an estimated 156,600 swim-up fry in July. Fry will be ponded in two Canadian troughs. In July and August, the fish will be split into six Canadian troughs at approximately 750fpp. In August at 330fpp, they will be moved outside 
to one Oregon raceway. In early October at $90 \mathrm{fpp}, 100 \%$ will be AD marked. In early November fish will be split to one Michigan series (3 raceways), and 20,000 will be LVCWT marked in each of the three raceways (Table 6). Fish will be approximately $4.5 \mathrm{fpp}$ at release.

\section{SPRING CHINOOK}

\section{A. 2006 Brood}

1. Smolt Goals/Rearing/Liberations - The Umatilla Subbasin spring Chinook planned allocation is 810,000 smolts.

Umatilla - All spring Chinook reared at Umatilla Hatchery will be acclimated at Imeques

C-mem-ini-kem acclimation facility (RM 79.5). In early October about 60,000 fish will be implanted with a CWT and LV fin clipped. All production will be AD clipped, but only CWT fish will have the additional LV fin clip. Two Michigan series with 360,000 fish will be transferred to Imeques in November 2007 at approximately 17fpp. Approximately 210,000 fish (20K ADLV) will be released in December, weather permitting, and 150,000 (20K ADLV) retained through the winter. The remaining 450,000 fish (20,000 ADLV) will be transferred to Imeques in mid to late January for acclimation and release in the Umatilla River. An estimated total of 600,000 smolts will be released in 2008, at approximately 15fpp. Fish will start an extended volitional release March 1. Remaining fish will be forced out no later than April 10. During the volitional release 2 dam boards will be removed to increase velocity through the pond.

Note: screens may be removed during winter period to expedite emergency releases, if necessary.

\section{B. 2007 Brood}

1. Broodstock/Egg Collection - Eggs for the Umatilla basin spring chinook program will be taken from the 560 adults or 280 pairs (1:1 sex ratio) plus 28 jacks. Fish are collected at TMFD and transferred to the South Fork Walla Walla facility. This should meet production goals with an estimated pre-spawning mortality of 3.6\% (20 fish). Adults were collected from April through June with the peak collection in May.

Approximately 1.08 million green eggs can be collected from 270 females spawned (fecundity @4,000). Individual fecundity estimates will be made (Section X). Fertilized eggs will be transferred and incubated at the Umatilla Hatchery.

Embryos may be culled and smolts may be segregated following ELISA examinations. Co-managers will consult to make decisions on culling and segregation once ELISA results are obtained. The overall goal is to only use eggs from females with OD values $<0.200$ units.

Note: Scales are collected from all unmarked adults in the broodstock.

2. Smolt Goals/Rearing/Liberations - The Umatilla Basin spring Chinook yearling production goal is 810,000 smolts.

Umatilla--In mid May 2008, approximately 850,000 fry will be ponded in one Oregon Raceway. These fish will be transferred to three Michigan ponds in late June and given a 28-day erythromycin feed treatment. In mid August, all fish will be Ad clipped and split into two Michigan series; 360,000 and 450,000. Prior to CWT tagging in early October, fish will be split into the remaining two series of Michigan. Final loading will occur in five Michigan series with 50,000 to 75,000 fish in each section.

In early October three groups of 20,000 fish (60,000 totals) will be implanted with a CWT and RV fin clipped. All production will be AD clipped, but only CWT fish will have RV fin clip. Two Michigan series with 360,000 fish will be transferred to Imeques in November 2007. Approximately 210,000 fish will be released in December, (20K ADRV) weather permitting and 150,000 retained through the winter. (20K ADRV) The remaining 450,000 fish (20K ADRV) will be transferred to Imeques in mid January for acclimation and release in the 
Umatilla River. An estimated total of 600,000 smolts will be released in March 2009, at approximately 15fpp. Fish will be volitional released for 1 to 3 weeks before being forced out. Note: The 20K CWT group scheduled for transfer in January should be spread evenly in the three sections; fish transferred in November should be loaded $n$ the B-bank.

\section{2008 Brood}

\section{1. $\quad$ Expected Run Size - 6,271 \pm 1,067}

Note: Run estimates include harvest downstream of TMFD.

2. Fish Disposition - A total of 20 CWT marked jacks (including any taken for brood) and 20 CWT mini-jacks will be sacrificed for wire recovery.

3. Broodstock/Egg Collection - Broodstock for Umatilla River spring Chinook production will be collected at Three Mile Dam based on the guidelines outlined in Table 5. If it is anticipated that the number of returning adults is not adequate to collect 560 adults (280 pairs), other locations where Carson stock is available, such as Carson or LWSH, maybe used. Jacks will be incorporated into the broodstock at a rate of 1 for every 10 adult males. When possible, CWT adults and jacks will be collected for broodstock. Chinook collected at Three Mile Dam will be transferred to the South Fork Walla Walla facility for holding and spawning. As a note, natural fish will be assumed to be collected in similar proportion as the run

Table 5. Collection guidelines for spring chinook broodstock.

\begin{tabular}{|l|c|c|c|c|}
\hline Total & Apr. 15-30 & May 1-15 & May 16-31 & June 1-15 \\
\hline $\begin{array}{l}560 \text { (adults) or } \\
280 \text { pairs }\end{array}$ & 66 & 221 & 220 & 53 \\
\hline 28 (jacks) & 0 & 2 & 14 & 12 \\
\hline $\begin{array}{l}\text { Jacks CWT } \\
\text { sampled }\end{array}$ & & & 10 & 10 \\
\hline Walla Walla & 59 & 197 & 196 & 48 \\
\hline WW jacks & 0 & 1 & 13 & 11 \\
\hline A target of 250 outplants are scheduled for the Walla Walla (See Section IX). \\
\hline
\end{tabular}

Adults kept for spawning at the South Fork Walla Walla facility will be injected with oxytetracycline and erythromycin upon sorting at the TMFD. A second injection of each antibiotic will be given in mid July at the South Fork facility. Prescriptions for using oxytetracycline, erythromycin, and formalin treatments will be developed by CTUIR, ODFW, and a veterinarian. Formalin treatments will be administered as needed (three to five days per week).

Minimum goals-- Collection rates at TMFD will also be adjusted to collect 70 pairs to produce a minimum green egg number of 280,000 (210,000 yearling smolts).

Walla Walla-The CTUIR and ODFW have agreed to release spring Chinook adults returning to the Umatilla River into Walla Walla River (Section XI). Umatilla broodstock is priority before outplants. No wild adults or CWT fish will be outplanted to the Walla Walla.

\section{FALL CHINOOK}

The Umatilla River fall chinook production (1.08 million) is divided in two programs, yearling and sub-yearling. Yearlings $(480,000)$ are reared at Bonneville Hatchery from adults returning to the TMFD. Sub-yearlings $(600,000)$ are reared at Umatilla Hatchery. In past years, eggs were collected at 
Priest Rapids. Funding may prohibit the ability to collect eggs. Therefore in 2007, eggs will be collected from TMFD with potential back-up egg supplies from Bonneville and Little White hatcheries

The Umatilla Hatchery sub-yearling program was reduced from 2.68 million to 600,000. The first reduced release was 2001. The reduction in sub-yearlings was implemented to evaluate survival rates from different release strategies in the Umatilla River. Strays into the Snake River is also a concern.

This reduction has created unused space at Umatilla Hatchery. Idaho Power Company has standing requested that ODFW rear 800,000 sub-yearling fall Chinook for release into the Snake River below Hells Canyon Dam. Production will not affect Umatilla River sub-basin releases.

\section{A. 2006 Brood}

1. Smolt Goals/Rearing/Liberations - The Bonneville Hatchery yearlings are from adult broodstock collected and spawned at TMFD. Embryos are incubated to the eyed stage at Umatilla Hatchery, transferred, and reared at Bonneville Hatchery. All production will be implanted with a wire tag, 430,000 with a agency/blank wire tag (BWT) and 50,000 with a CWT. All CWT fish are externally marked with AD clip.

Smolts will be released in two groups of approximately 240,000 fish each. Each group is represented by 25,000 CWT. The first group will be acclimated from Thornhollow (RM 73.5), and the second Pendleton (RM56). Fish will be transferred in the week of February 11 and released in mid-March 2008. Each group will be volitionally released for one week before forced out. Target size is $10 \mathrm{fpp}$.

\section{B. $\quad 2007$ Brood}

\section{Expected Run Size $-1,236 \pm 452$}

2. Fish Disposition - A total of 90 adult, 30 jack, and 20 minijack CWT recoveries are needed for wire recovery. These recoveries may come from either broodstock or sacrificed at TMFD. See Table 6 for CWT collection guidelines. All unmarked fish will be checked for blank wire tags. Carcasses will be distributed by CTUIR. Scales will be taken from unmarked broodstock.

Up to 1,000 fall chinook adults may be transferred from Ringold to the Umatilla River above TMFD to augment natural production or used for broodstock. These fish will be released at Yoakum or Barnhart.

\begin{tabular}{|l|c|c|c|}
\hline \multicolumn{4}{|c|}{ Table 6. Fall Chinook CWT collection guidelines for TMFD. } \\
\hline Total & September & October & November \\
\hline 90 Adults & 12 & 62 & 16 \\
\hline 30 Jacks & 7 & 21 & 2 \\
\hline 20 Minijacks & 3 & 16 & 1 \\
\hline
\end{tabular}

3. Broodstock/Egg Collection - Broodstock for Umatilla River fall Chinook production will be collected at Three Mile Falls Dam based on the guidelines outlined in Table 7. Natural fish will be assumed to be collected in similar proportion as the run.

\begin{tabular}{|l|c|c|c|c|}
\hline \multicolumn{5}{|l|}{ Table7. Fall Chinook broodstock collection guidelines for TMFD. } \\
\hline Total & Sept. & Oct. 1-15 & Oct. 16 -31 & Nov 1 -15 \\
\hline 850 (adults) & 115 & 329 & 255 & 151 \\
\hline 43 (jacks) & 11 & 21 & 8 & 3 \\
\hline
\end{tabular}


Fall Chinook broodstock will be collected at TMFD. Egg source priorities for Umatilla Hatchery will be in the preceding order: TMFD, Bonneville and Little White Salmon hatcheries. Umatilla Hatchery requires approximately 1,600,000 green eggs to produce 1,230,000-eyed eggs. Jacks will be incorporated into the broodstock at a rate of one for every 10 adult males. As many CWT adults and jacks as possible will be included in the broodstock. The broodstock collection rate will be adjusted as necessary. It is expected that all the fish will be needed to meet production goals (fecundity @ 3,800).

Notes: Scales should be collected from unmarked adults used for broodstock .

Umatilla hatchery staff will experiment with delayed fertilization on selected eggs takes in an attempt to improve survival.

All non-ripe fish arriving prior to November $5^{\text {th }}$ will be injected with oxytetracycline and erythromycin. New arrivals after November $5^{\text {th }}$ will not be injected. Only females spawned prior to November 16 will be used for the sub-yearling program.

\section{Sub-yearling and Yearling Goals/Rearing/Liberations -}

Sub-yearling- The Umatilla Hatchery fall chinook sub-yearling production goal is 600,000. Fry swim-up in mid-February 2007. Approximately 625,000 swim-up fry will be placed in one Oregon pond. In mid March, the fish will be split into two Michigan ponds. Marking of 600,000 sub-yearlings for the Umatilla program will begin in early March and will be completed mid April. All fish will be marked with a CWT and AD fin clip and loaded evenly into four Oregon ponds to evaluate two release strategies.

Strategy 1 -One group of approximately 300,000 fish will be transferred to Thornhollow acclimation ponds in early May at approximately 50fpp, held for two weeks, volitionally released for one week, and forced out in late May 2008.

Strategy 2 - A second group of 300,000 fish will be released directly into the Umatilla River at Reith (RM 48) in late May 2008. Target size at release is 40fpp. Release time into the Umatilla River is dependent on river flows and temperatures

Yearling-The Bonneville Hatchery John Day mitigation fall chinook yearling production goal for the Umatilla River is 480,000 smolts.

All fish will be marked with either a BWT $(430,000)$ or ADCWT $(50,000)$. Half the fish will be acclimated at Thornhollow (RM 73.5) and half at Acclimation period will be from midFebruary to March. Target size in both groups is 10fpp.

\section{Idaho Power Company-Sub-yearling/Goals/Rearing/Liberations -}

Sub-yearling- The Snake River fall Chinook sub-yearling production goal is 800,000 sub-yearlings for release in the Snake River. Fry will swim-up in mid-February 2008. Approximately 825,000 swim-up fry will be reared to produce 800,000 fish. Marking of subyearlings will begin in late March and will be completed in early April. All fish will be ad clipped and up to 400,000 CWT. Target size is 50fpp. Transfers, liberations and monitoring are the responsibility of Idaho Power Company (IPC).

IPC contract will subsidize Umatilla BPA contract for 3 months of permanent Tech 1 time, and pay additional costs (utilities, fish, marking, and field supplies) to rear fish. The BPA Umatilla contract may be reduce in the amount of the 3 months of Tech 1 time and their indirect charges.

\section{COHO}

\section{A. 2006 Brood}

1. Smolt Goals/Rearing/Liberations - The Mitchell Act Coho production goal for the Umatilla River is 1,500,000 smolts. Production is divided between two facilities; one million smolts are produced at Cascade Hatchery, and half million are produced from Oxbow Hatchery 
and Lower Herman Pond. Two groups of approximately 500,000 and 1,000,000 smolts are acclimated. The first period consists of 500,000 smolts acclimated from mid-February to midMarch and second group of 1,000,000 smolts from mid-March to mid-April.

Oxbow Hatchery and Lower Herman Creek Pond - A total of 500,000 smolts will be transferred the week of February $11^{\text {th }}$ and released mid-March 2008 from two Pendleton ponds. This group is represented with a 25,000 AdCWT mark. Target size is 18fpp although fish are typically smaller. These fish will be volitionally released for one week and then forced out.

Cascade Hatchery-A total of 1,000,000 smolts will be transferred week of March $18^{\text {th }}$ and released in mid-April 2008 from four Pe3ndleton Ponds. This group will be represented by 225,000 ADCWT groups. During the second acclimation, three Pendleton ponds (approximately 750,000 fish) will be volitional released for one week prior to forced release. The other pond (approximately 250,000 fish) will be force released in early April to create space for steelhead acclimation. Target size is $15 \mathrm{fpp}$, however, fish are typically smaller.

Note: Release groups in 2009 will only require two-25,000 Ad CWT groups, one from Oxbow and one from Cascade hatcheries.

\section{B. 2007 Brood}

\section{Expected Run Size $-\mathbf{1 0 , 7 0 0}$}

2. Fish Disposition -- One hundred AdCWT adults will be sacrificed. It is anticipated that all AdCWT fish collected will need to be sacrificed for CWT recovery. Co-managers will consult in the UMMEOC forum on the collection rate if the numbers exceed what is anticipated. Carcasses will be distributed by CTUIR.

All remaining unmarked adults and jacks will be released at TMFD regardless of stream flow. Data will be collected on fish released upstream including sex and age class. Age classes will be divided between jacks ( $<18 ")$ and adults (18" and larger).

3. Broodstock/Egg Collection - Broodstock will be collected, held and spawned at Bonneville Hatchery. Green eggs will be transported to Cascade and Oxbow Hatcheries for incubation and rearing. If additional adults are needed to meet production goals, adults can be collected, held and spawned at TMFD.

\section{HATCHERY MONITORING AND EVALUATION (ODFW)}

A. Steelhead

1. Umatilla Hatchery, 2007 brood- Determine and compare rearing performance, smolt condition, juvenile migration performance, and smolt-to-adult survival of steelhead released from the Minthorn and Pendleton facilities, and those direct stream released near Bonifer site. Lengths (300), weights (100), smolt conditions, and descaling (100) will be sampled from fish at transfer to and release from acclimation facilities. Thornhollow may be used in low river flow emergencies. To determine juvenile migration performance to TMFD, John Day and Bonneville Dams approximately 1,000 fish per raceway will be PIT tagged. To determine smolt-to-adult 
survival we will ADLV+CWT mark 20,000 fish from each of the three release groups. All remaining fish will be marked $\mathrm{AD}$.

\section{B. Spring Chinook salmon}

1. Umatilla Hatchery, 2006 brood yearlings- Determine and compare rearing performance, smolt condition, juvenile migration performance, and smolt-to-adult survival of each of three yearling spring Chinook salmon release groups (standard transfer released in March, fall transfer released in March, and fall transfer released in December). Lengths (300), weights (100), smolt conditions, and descaling (100) will be sampled from fish at transfer to and release from acclimation facilities. To determine migration performance we will PIT-tag 1,500 fish from one Michigan series for each of two fall transfer release group (3 raceways) in October 2006 and transfer them to Imeques acclimation facilities. An additional group of 1,500 will be PIT-tagged in one Michigan series (3-raceways) of the standard release group in January 2007.

2. Umatilla Hatchery, $\mathbf{2 0 0 7}$ brood yearlings To determine smolt-to-adult survival we will mark 20,000 fish from each of the three release groups with ADRVCWT in Michigan series. All remaining production will be AD clipped.

\section{Fall Chinook salmon}

1. Umatilla Hatchery, 2007 brood sub-yearlings- Determine and compare rearing performance, smolt condition, juvenile migration performance, and smolt-to-adult survival between subyearling fall Chinook salmon reared in Oregon raceways and acclimated for one month and those directly released into the Umatilla River. Lengths (300), weights (100), smolt conditions, and descaling (100) will be sampled from fish at transfer to and release from acclimation raceways.

To determine juvenile migration performance we will PIT tag 300 fish in each of four Oregon ponds/raceways in May 2007. To determine and compare smolt-to-adult survival of the two release groups we will mark ADCWT $100 \%$ of the production.

2. Bonneville Hatchery, 2006 brood yearlings- Determine and compare smolt condition, and smolt-to-adult survival of yearling fall chinook salmon release at Thornhollow and Pendleton. Lengths (300), weights (100), smolt conditions, and descaling (100) will be sampled from fish at transfer to and release from acclimation raceways. To determine and compare smolt-to-adult survival release groups, 25,000 fish from each of the two release groups will be marked ADCWT. All remaining fish will be marked BWT (available funding).

D. All broods-Determine and compare smolt-to-adult survival, fishery contribution, straying, relative smolt-to-survival, adult production, Umatilla River return, and life history characteristics of all rearing and release strategies from groups at Umatilla and Bonneville Hatcheries. Table 8 presents the CWT and PIT tagging plan for hatchery monitoring and evaluation for fish released in 2008.

Table 8. Fish marking summary for hatchery monitoring and evaluations efforts in 2008.

\begin{tabular}{|c|c|c|c|c|c|c|c|c|c|c|}
\hline $\begin{array}{l}\text { Species/ } \\
\text { strategy }\end{array}$ & $\begin{array}{l}\text { System or } \\
\text { Hatchery }\end{array}$ & $\begin{array}{l}\text { Number } \\
\text { raceway }\end{array}$ & $\begin{array}{c}\text { Total } \\
\text { number }\end{array}$ & $\begin{array}{l}\text { Number } \\
\text { CWT }\end{array}$ & $\begin{array}{c}\text { Number } \\
\text { BWT }\end{array}$ & $\begin{array}{c}\text { Tagging } \\
\text { Date }\end{array}$ & $\begin{array}{l}\text { Number } \\
\text { PIT-tag }\end{array}$ & $\begin{array}{l}\text { PIT-tag } \\
\text { Date }\end{array}$ & $\begin{array}{c}\text { Release } \\
\text { Date } 2008\end{array}$ & Study \\
\hline Steelhead & Michigan & $1(\mathrm{~A}, \mathrm{~B}, \mathrm{C})$ & $150 \mathrm{~K}$ & $\begin{array}{c}60 \mathrm{~K} \\
(3 \times 20 \mathrm{~K})\end{array}$ & 0 & Nov 07 & TBA & Jan 08 & April & $\begin{array}{l}\text { Production } \\
\text { Monitoring }\end{array}$ \\
\hline$\underline{\mathrm{BOR}}$ & & & & & & & 4500 & Jan 08 & April & Production \\
\hline
\end{tabular}

Spring Chinook

Yearling

Michigan $5(\mathrm{~A}, \mathrm{~B}, \mathrm{C}) \quad 810 \mathrm{~K}$

$60 \mathrm{~K}$
$(3 \times 20 \mathrm{~K})$

$\begin{array}{lllll}0 & \text { Sept } 07 & 2300 & \text { Nov } 07 & \text { Dec } 08\end{array}$

Production \& Release strategy 


$\begin{array}{cccc}2300 & \text { Jan 08 } & \text { March } & \begin{array}{c}\text { Monitoring } \\ \text { Production \& } \\ \text { Release strategy } \\ \text { Monitoring }\end{array} \\ \text { 2300 } & \text { Jan 08 } & \text { March } & \begin{array}{c}\text { Production \& } \\ \text { Release strategy } \\ \text { Monitoring }\end{array}\end{array}$

\begin{tabular}{|c|c|c|c|c|c|c|c|c|c|c|}
\hline \multicolumn{11}{|l|}{ Fall Chinook } \\
\hline Subyearling & Oregon & 4 & $600 \mathrm{~K}$ & $\begin{array}{c}600 \mathrm{~K} \\
(4 \times 150 \mathrm{~K})\end{array}$ & 0 & Apr 08 & 1600 & May 08 & May & $\begin{array}{l}\text { Rearing } \\
\text { \& Release } \\
\text { Monitoring }\end{array}$ \\
\hline Yearling & Bonneville & 8 & $480 \mathrm{~K}$ & $\begin{array}{c}50 \mathrm{~K} \\
(2 \times 25 \mathrm{~K})\end{array}$ & $430 \mathrm{~K}$ & Aug 07 & 0 & $\begin{array}{l}\text { Feb } 08 \\
\text { Mar } 08\end{array}$ & $\begin{array}{c}\text { March and } \\
\text { April }\end{array}$ & $\begin{array}{l}\text { Production \& } \\
\text { Release strategy } \\
\text { Monitoring }\end{array}$ \\
\hline \multicolumn{11}{|l|}{$\underline{\text { Coho }}$} \\
\hline & Cascade & 11,12 & $1,000 \mathrm{~K}$ & $25 \mathrm{~K}$ & 0 & Aug 07 & 0 & Feb 08 & March & $\begin{array}{l}\text { Mitchell Act } \\
\text { Production }\end{array}$ \\
\hline & Herman Cr. & 1 & $500 \mathrm{~K}$ & $25 \mathrm{~K}$ & 0 & Aug 07 & 0 & Mar 08 & April & $\begin{array}{l}\text { Mitchell Act } \\
\text { Production }\end{array}$ \\
\hline
\end{tabular}

\section{FISH HEALTH MONITORING (ODFW)}

A. Summer Steelhead

1. 2006 \& 2007 Brood Umatilla Hatchery Juveniles - Monthly monitoring and preliberation examinations as defined in the Umatilla Hatchery Fish Health Monitoring and Evaluation (FHME) work statement.

2. 2008 Brood Minthorn Pond Adults - (as described in the statement of work). On the first spawning day at Minthorn, La Grande staff will be present to provide sampling supplies and guidance on procedures for collecting samples. CTUIR fisheries staff may be requested to do sampling on some spawning days if ODFW staff is not available.

Hydrogen peroxide treatments will be administered for fungus control five days per week beginning in February under protocols developed and implemented by CTUIR and ODFW personnel. The CTUIR fishery staff will document and save all adult mortality for fish health to examine.

\section{B. Spring Chinook}

1. 2008 Brood Umatilla Hatchery Yearlings - Monthly monitoring and pre-liberation examinations at Umatilla Hatchery as defined in the Umatilla Hatchery FHME work statement. For fish transferred to Imeques C-mem-ini-kem on about November 1, 2007 for rearing until spring release, monthly monitoring and pre-liberation examinations will follow the same protocols as for Umatilla Hatchery.

2. 2007 Brood South Fork Walla Walla Facility Adults - Brood stock monitoring on spawned adults as defined in the Umatilla Hatchery FHME work statement. All spawned females will be sampled for $R$. salmoninarum. The overall goal will be to only use eggs from females with ELISA values $<0.200$ OD units.

Prescriptions for using oxytetracycline and erythromycin injections at Three Mile Dam and South Fork Walla Walla facilities will be cooperatively developed by ODFW, CTUIR, and a veterinarian. A prescription for formalin treatments at the south Fork facility will also be cooperatively developed. 
Monitoring of pre-spawning mortality for systemic bacteria, including Renibacterium salmoninarum will be conducted on either fresh or frozen carcasses. CTUIR fisheries staff will document and save all needed carcasses

C. Fall Chinook

1. 2006 Brood Bonneville Hatchery Yearlings - Monthly monitoring and pre-liberation examinations by ODFW Clackamas Fish Health staff. Monitoring will be by standard protocols used by the ODFW.

2. 2007 Brood Umatilla Hatchery Sub-yearlings - Monthly monitoring and pre-liberation examinations as defined in the Umatilla Hatchery FHME work statement. At Thornhollow, a pre-liberation examination will be required if a fish health examination has not been conducted within six weeks of the release date.

3. $\quad 2007$ Brood Bonneville Hatchery Yearlings - Monthly monitoring by ODFW Clackamas Fish Health staff. Monitoring will be by standard protocols used by the ODFW. 4. Idaho Power Company-2007 Brood Lyons Ferry Sub-yearlings - Request for eyed eggs from 465 females that tested low ( $<0.2$ titers) for BKD. Eggs will be transferred to Umatilla Hatchery in mid-December 2006 from Lyons Ferry Hatchery. Eggs will be disinfected with 100ppm iodophor for 10 minutes. Females will also be sub-sampled for viral pathogens. Subyearling will be monitored and thoroughly examined 45 days prior to release as defined in the Idaho Power Company work statement. All activities will be by the ODFW La Grande Fish Health staff.

5. $\quad 2007$ Brood Three Mile Falls Dam Facility Adults - Brood stock monitoring as defined in the Umatilla Hatchery FHME work statement. All spawned females will be sampled for $R$. salmoninarum. The overall goal will be to only use eggs from females with ELISA values $<0.200$ OD units.

Hydrogen peroxide will be used to control fungus. A prescription to use hydrogen peroxide and inject oxytetracycline and erythromycin will be provided by a veterinarian.

Pre-spawning mortality will examined for systemic bacteria, including $R$. salmoninarum, on either fresh or frozen carcasses. CTUIR staff will document and save all needed carcasses.

6. 2007 Bonneville Hatchery Adults - Brood stock monitoring by ODFW Fish Health staff. Monitoring will be by standard protocols used by the ODFW.

D. Coho

1. 2006 Brood Cascade Hatchery and Lower Herman Creek Pond Yearlings - Monthly and pre-liberation monitoring by ODFW Clackamas Fish Health staff. Monitoring will be by standard protocols used by the ODFW. At acclimation, a pre-liberation examination will be required if a fish health examination has not been conducted within six weeks of the release date. 2. 2007 Brood Cascade Hatchery Adults - Brood stock monitoring by ODFW Clackamas Fish Health staff. Monitoring will be by standard protocols used by the ODFW.

\section{NATURAL PRODUCTION EVALUATION (CTUIR)}

A. Monitor natural spawning activities of hatchery and natural adult spring Chinook coho salmon, and summer steelhead in the Umatilla River Basin.

B. Estimate tribal harvest of adult salmon and steelhead returning to the Umatilla River Basin.

C. Determine age, growth of spring Chinook salmon and summer steelhead in the Umatilla River Basin.

D. Salvage stranded salmon or steelhead as needed 


\section{Interim Umatilla Basin Spring Chinook Management Guidelines (2008)}

In the mid-1980s, spring Chinook salmon had been absent from the Umatilla River Basin for over 70 years. Losses were generally attributed to water diversions and stream habitat degradation within the basin and impacts related to the Federal hydropower system in the mainstem Columbia River. A comprehensive Umatilla Restoration Plan was developed (Boyce 1986) that identified habitat restoration, tributary passage improvement and artificial propagation measures to restore salmonid populations to the Umatilla River. As part of this basin restoration effort, spring chinook juveniles produced at several different hatchery facilities were released into the Umatilla River beginning in 1986 with the intent of providing for fisheries and restoring natural production.

In 1989, a Umatilla Hatchery Program Master Plan was developed. The Master Plan identified facility construction needs (Umatilla Hatchery and satellite facilities) and outlined spring chinook production objectives as well as establishing goals for adult returns, natural production and harvest. Many changes have been made to the artificial production program through the years, however the overall goals for the spring chinook program as outlined in the Master Plan have guided operation of the program until recently. In 2001, the Umatilla Subbasin Summary was developed which reassessed the Master Plan goals for spring chinook and established new goals for the program.

The Subbasin Summary identified an adult return goal of 8,000 spring chinook returning to the mouth of the Umatilla River. Of the 8,000, 6,000 were anticipated to be hatchery fish and 2,000 were expected to be natural origin adults. Disposition of these 8,000 adults was outlined in the Subbasin Summary as follows; 3,000 for natural spawning escapement (producing 2,000 actual spawners), 1,000 for broodstock, and 4,000 for harvest. Since the Subbasin Summary was produced, the proposed expansion of the artificial production program identified in that document has been dropped from consideration lowering the broodstock need to 560 adults. In addition, further assessment of the quality and quantity of available habitat has determined that under current habitat conditions fewer spawners can be supported than identified under the long term goals. Also, prespawning mortality losses are much higher than previously estimated. Lastly, a new objective, providing adults to the Walla Walla River for natural spawning enhancement monitoring and evaluation has been identified. In response to these new goals and objectives, a management guidelines table (attached) has been developed that designates the number of adults for each purpose at varying return levels.

In order to avoid annual negotiations regarding management decisions for spring chinook, Umatilla Basin co-managers have agreed to use these management guidelines for setting the annual disposition of adult spring chinook returning to the Umatilla River for the next two years, or until an agreement is reached that supercedes these guidlines. This will allow harvest levels, broodstock collection rates, and transfer numbers to be determined based on the annual run projection and incorporated into the Umatilla Basin and Hatchery Annual Operating Plan (AOP). There are two general attributes in common to all the disposition categories; 1) the total number of fish includes both natural and hatchery origin adults and no differentiation is placed on origin for any disposition category (with exception of Walla Walla Outplanting) and 2) includes only true adults and not jacks. Following are the details for each disposition category in the table.

\section{$\underline{\text { Total Run Size }}$}

- This is the preseason estimate forecasted in the AOP for number of adults returning to the mouth of the Umatilla River.

- In-season adjustments may be made to follow the management guidelines if significant differences between forecasted and actual adult return numbers are observed. 


\section{Broodstock}

- The broodstock collection goal for the current 810,000 yearling smolt production programs is 560 adults.

- Broodstock will be collected at 50:50 male to female ratio.

- Adults will be collected from a cross section of the run returning to Threemile Dam based on a five year running historical average of return timing.

- A minimum program size of 270,000 yearling smolts will be maintained (200 brood).

- At run sizes less than 750 adults, attempts will be made to fulfill the Umatilla program broodstock need from other Carson stock sources in the following priority: 1) Little White Salmon NFH; 2) Carson NFH; and 3) other mid Columbia stations.

\section{Spawning Escapement}

- The number of fish identified in the spawning escapement total is the sum of actual spawning fish and those lost to prespawning mortality.

- Percent prespawning loss is estimated to be approximately 54\% (Range 40 - 68\%) under current habitat conditions.

- Under current habitat conditions, an estimated escapement of 1,875 adults would fully seed the available habitat capacity (600 spawners) under the poorest pre-spawner survival conditions.

- Spawning escapement will be managed for a maximum of 1,875 adults over the next two years. At the end of that period, habitat conditions will be reassessed to determine whether the spawning escapement goal should be changed.

- The long term escapement goal remains at 3,000 adults. This will be contingent on additional habitat enhancement occurring in the upper mainstem Umatilla River and Meacham Creek.

\section{Walla Walla Outplants}

- Outplants into the South Fork Walla Walla River will continue for reintroduction and monitoring and evaluation efforts.

- $\quad$ No coded-wire-tagged or unmarked adults will be hauled to the Walla Walla River.

- Adults will be collected from a cross section of the run returning to Threemile Dam.

\section{$\underline{\text { In-River Harvest }}$}

- The in-river harvest total includes both Indian and non-Indian fisheries.

- Total harvest is to be proportioned at 50\% each for Indian and non-Indian fisheries.

- The harvest goal of 4,000 adults would be achieved at run sizes of 7,000 to 8,000 fish.

Umatilla River Adult Spring Chinook Management Guidelines

\begin{tabular}{|c|c|c|c|c|}
\hline Total Run Size & Broodstock & $\begin{array}{c}\text { Spawning } \\
\text { Escapement }\end{array}$ & $\begin{array}{c}\text { Walla Walla } \\
\text { Outplanting }\end{array}$ & $\begin{array}{c}\text { In-River Harvest } \\
\text { (\% of run) }\end{array}$ \\
\hline 250 & 200 & 50 & 0 & $0(0 \%)$ \\
\hline 500 & 400 & 100 & 0 & $0(0 \%)$ \\
\hline 750 & 560 & 150 & 0 & $0(0 \%)$ \\
\hline 1000 & 560 & 400 & 0 & $0(0 \%)$ \\
\hline 1500 & 560 & 600 & 0 & $300(20 \%)$ \\
\hline 2000 & 560 & 800 & 200 & $440(22 \%)$ \\
\hline
\end{tabular}




\begin{tabular}{|c|c|c|c|c|}
\hline 2500 & 560 & 1000 & 250 & $690(28 \%)$ \\
\hline 3000 & 560 & 1200 & 300 & $940(31 \%)$ \\
\hline 3500 & 560 & 1400 & 350 & $1190(34 \%)$ \\
\hline 4000 & 560 & 1600 & 400 & $1440(36 \%)$ \\
\hline 4500 & 560 & 1800 & 450 & $1690(38 \%)$ \\
\hline 5000 & 560 & 1875 & 500 & $2065(41 \%)$ \\
\hline 5500 & 560 & 1875 & 600 & $2465(.45 \%)$ \\
\hline 6000 & 560 & 1875 & 700 & $2865(.48 \%)$ \\
\hline 6500 & 560 & 1875 & 800 & $3265(.50 \%)$ \\
\hline 7000 & 560 & 1875 & 900 & $3665(.52 \%)$ \\
\hline 8000 & 560 & 1875 & 1000 & $4565(.57 \%)$ \\
\hline
\end{tabular}

\section{Bureau of Reclamation Monitoring and Evaluation Program}

\section{Summer Steelhead - 2007 Brood}

The Lower Columbia Area Office for the Bureau of Reclamation (BOR) has requested 10,000 ad clipped Umatilla Hatchery summer steelhead smolts (HSTS) to assess take in BOR operated Feed and Maxwell irrigation canals. This assessment was required in the 2004 BiOp. The assessment contains two components. First component will assess take from production releases of steelhead as they migrate through the Umatilla River; the second component will assess take with multiple insertion of fish near the canals intakes through the spring and summer 2008. The first component requires approximately 4,500 smolts, 1,500 for each release site; the second component requires approximately 5,500 fish for multiple insertion releases in 2008. BOR will provide PIT tags (model \#TX1411SGL or alternative) and Bonneville Power Administration (BPA) will fund ODFW staff (through their ongoing M\&E project) to insert production release PIT tags. Holding location of insertion fish will be at Irrigon Hatchery through an MOU agreement.

ODFW M\&E staff will insert 4,500 fish with PIT tags between January and March 2007 to assess the production releases. These fish will be utilized for the out migrations study as well as take assessment. CTUIR M\&E staff will insert 5,500 fish with PIT tags in late winter or early spring to assess the insertion releases and associated take. CTUIR activities are funded by BOR in a separate contract.

Fish and Wildlife Service, Abernathy LAB, will provide technical expertise and monitoring of the detection systems at Feed and Maxwell Canals and TMFD. Additional systems maybe installed later, if needed. Pending results will determine the number of PIT fish for ongoing studies.

BOR will also contract with CTUIR to survey and salvage stranded fish within the Feed and Maxwell canals after the irrigation season when facilities are shutdown. 